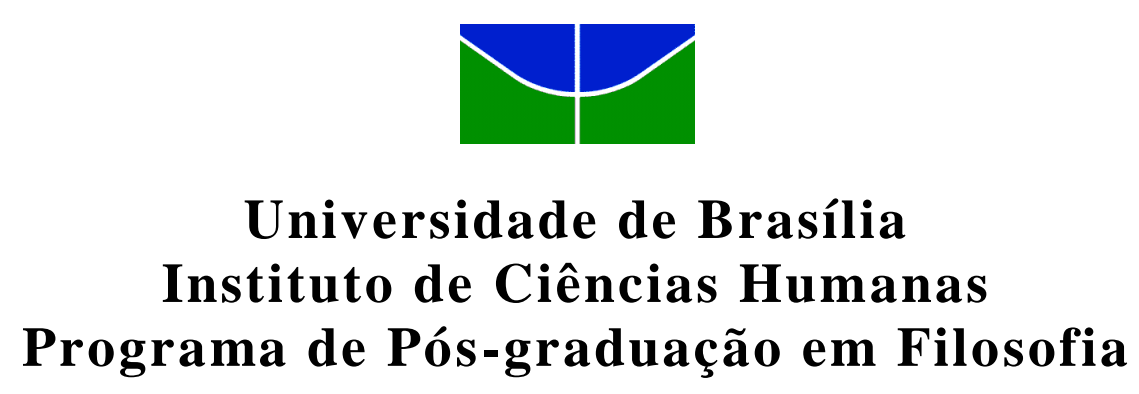

\title{
A FILOSOFIA DA RELIGIÃO DE KANT E ASPECTOS DE SUA INFLUÊNCIA NO DEBATE CONTEMPORÂNEO SOBRE O PLURALISMO
}

ERNESTO JOSÉ MARTINS CAETANO

Dissertação apresentada ao Programa de Pós Graduação em Filosofia da Universidade de Brasília (UnB), em 24 de fevereiro de 2015, como requisito para obtenção do título de Mestre em Filosofia. Orientador: prof. Dr. Agnaldo Cuoco Portugal 


\section{Agradecimentos}

Agradeço ao meu orientador professor Agnaldo Cuoco Portugal pela orientação deste trabalho, pela tranquilidade diante de impasses e pela insistência para fazer com que tudo dê certo. Agradeço ao professor José Pedro Luchi por sua iluminação racional que sempre encheu as salas de aula, e por ter sido um dos principais responsáveis pelo meu aperfeiçoamento na graduação. Agradeço ao professor Marcio Gimenes por ter feito parte da banca de qualificação, que ao lado do professor Alexandre Hahn, foi decisivo na elaboração desta dissertação. Agradeço a banca de defesa por aceitar fazer parte de mais esta etapa.

Agradeço à Cintia Braga, minha companheira e amiga, por quem meu impulso fundamental para viver ganha força todos os dias diante do brilho do seu olhar.

Agradeço à minha família. Agradeço a minha mãe Jailma, por ser a amiga que eu sei que posso recorrer à procura de uma disposição para amar. Agradeço ao meu Pai José Caetano por ficar contente e mais forte diante das minhas vitórias. Agradeço aos meus irmãos Grazielle, Christiane e Fabio, que formam um coro de rogos junto a Deus, que me enche de força diante das calamidades. Agradeço a minha sogra Leidimar que soube ser solidária nos momentos que foi solicitada.

Agradeço ao meu amigo Reginaldo, que solicitamente compartilhou seu apartamento em Brasília, além de compartilhar momentos importantes comigo durante a elaboração deste trabalho.

Agradeço a todos os amigos que de algum modo me incentivaram. 
À Cintia Braga 
(...) o invisivel precisa de ser representado no homem por algo visivel (sensível) (Kant, 1793/2008, p.194). 


\section{RESUMO}

Esta dissertação tem como tema a filosofia da religião de Kant e aspectos de sua influência no debate contemporâneo sobre o pluralismo. No primeiro capítulo mostraremos como, no pensamento moral de Kant, emerge o conceito de religião da razão. Constataremos que o conceito de religião da razão promana da moral. Por isso, a religião que daí emerge é religião natural e não revelada. No segundo capítulo mostraremos que o conceito de religião da razão será o intérprete de todas as religiões positivas. A religião positiva é representação simbólica da religião da razão. Enquanto representação simbólica ela não é ainda religião da razão. A religião positiva tem a função de promover a moralidade. Enquanto realiza a sua tarefa ela deve ceder lugar para a única religião da razão. Nessa interação a religião da razão tem a primazia e a religião positiva é submetida pelo critério moral que promana do conceito racional de religião. No último capítulo mostraremos que grande parte filosofia da religião posterior a Kant e desde Schleiermacher, chegando à filosofia da religião contemporânea, passou a adotar outro viés de interpretação da religião positiva. Embora o viés tenha sofrido uma alteração no foco, Kant continua a exercer influência na filosofia contemporânea, principalmente na atual hipótese do pluralismo religioso de John Hick.

Palavras-chave: Kant, religião, moral, Religião racional, religião positiva. 


\begin{abstract}
The purpose of this investigation was to determine whether Kant's Philosophy of Religion would influence on contemporary debate of Pluralism. The first chapter shows how, in the moral thinking of Kant, emerges the concept of the Religion of Reason. We can see that Kant's concept of rational religion comes from morality. Therefore, the religion that emerges is natural religion and not revealed. The second chapter shows that the concept of religion of reason will be the interpreter of all positive religions. Positive religion works as a kind of symbolic representation, and as far as it is concerned, it is not yet the Religion of Reason. Positive Religion's role is to promote morality. To perform its task, it must give way to the only religion of reason. In this interaction the Religion of Reason comes first and the Positive Religion is submitted by the moral criterion that comes from the rational concept of religion. The last chapter will show that the majority of philosophical thought about religion after Kant and since Schleiermacher, till the contemporary philosophy of religion, starts to adopt another perspective of interpretation of positive religion. Although this perspective has changed in focus, Kant continues to exercise influence in contemporary philosophy, especially in the current hypothesis of religious pluralism of John Hick.
\end{abstract}

Keywords: Kant, religion, morality, rational religion and positive religion. 
INTRODUÇÃO...................................................................................................... 08

1. O CONCEITO DE RELIGIÃO RACIONAL................................................... 14

1.1 A RELIGIÃO MEDIADA PELA MORAL 14

1.2 IMPERATIVO CATEGÓRICO 17

1.3 CRÍTICA DA RAZÃO PRÁTICA E FACTUM DA RAZÃO 25

1.4 LIBERDADE 26

1.4.1 LIBERDADE: UMA PROVA TEÓRICA 27

1.4.2 LIBERDADE: UMA PROVA PRÁTICA 29

1.5 SENTIMENTO MORAL 31

1.6 SUMO BEM E O CONCEITO DE RELIGIÃO 38

1.6.1 IMORTALIDADE DA ALMA 47

1.6.2 O POSTULADO DE DEUS 51

2. A RELIGIÃO RACIONAL E A RELIGIÃO ESTATUTÁRIA OU POSITIVA............................................................................................... 57

2.1PROPENSÃO PARA O MAL 63

2.2 A POSSIBILIDADE DE CONVERSÃO MORAL 72

2.3O SUMO BEM COMUNITÁRIO (IGREJA INVISÍVEL) E

A IGREJA VISÍVEL (HISTÓRICA OU ESTATUTÁRIA)

2.4A CRíTICA DE KANT À RELIGIÃO ESTAUTÁRIA 86

2.5 SUPERAÇ̃̃O DA RELIGIÃO ESTATUTÁRIA 95

3. O CONCEITO RACIONAL, EXPERIÊNCIA RELIGIOSA E PLURALIDADE DAS RELIGIÕES................................................................. 99

3.1 KANT E A PRIORIDADE DO CRISTIANISMO 100

3.2 SCHLEIERMACHER E A ESPECIFIDADE DA RELIGIÃO 106

3.3 JOHN HICK E O PLURALISMO RELIGIOSO 115

3.3.1 A RELIGIÃO COMO CAMINHO DE SALVAÇÃOO 121

3.3.2 A HIPÓTESE PLURALISTA DE HICK 125

CONCLUSÃO................................................................................................................ 128

REFERÊNCIAS................................................................................................. 132 


\section{Introdução}

Este trabalho tem como tema a filosofia da religião de Kant e aspectos de sua influência no debate contemporâneo sobre o pluralismo, a partir, principalmente, dos textos Crítica da razão prática [1788] (2002) e A Religião nos Limites da Simples Razão [1793] (2008). Como comentador principal, usarei o livro Religião e História de Francisco Herrero. Kant, na Crítica da razão prática[1788] (2002) parte da moral e expõe o seu conceito de religião racional ou moral e no A Religião nos Limites da Simples Razão [1793] (2008), ele aplica o conceito de religião racional às religiões positivas, principalmente o cristianismo. Usaremos também o trabalho de John Hick, Teologia cristã e pluralismo religioso: o arco-íris das religiões(2005) para sermos introduzidos no atual debate sobre o pluralismo religioso.

Parte-se do princípio de que atualmente um dos interesses pelo estudo da religião na academia é uma resposta ao avanço cada vez maior de diversos credos religiosos compondo o mesmo espaço. Nas grandes cidades ocidentais, no contexto atual, já não é novidade a convivência de várias religiões distintas. Muçulmanos, hinduístas, budistas, confucionistas, taoístas, entre outras religiões, se espalham por todos os cantos do mundo ocidental. O estudo da religião terá, nesse contexto, a contribuição do pensamento de Kant. A proposta de fazer ver a relação entre religião racional e religiões positivas no pensamento de Kant pode contribuir para o debate atual do papel das religiões na vida das sociedades globalizadas.

No primeiro capítulo da dissertação, partiremos da relação que Kant estabelece entre moral e religião para compreendermos o seu conceito racional de religião. Na Crítica da razão prática [1788], Kant diz que a razão é prática em si mesma. Isso significa que a razão é capaz de ditar uma lei moral (independente da experiência) obrigatória para todas as ações. Entretanto, como o homem também é movido por inclinações subjetivas (que têm origem no sentimento) que resultam de representações de objetos da experiência, a lei moral é um dever para todo ser racional e sensível. Em vista disso, o homem deve se esforçar (virtude) para cumprir o dever que lhe é 
prescrito pela razão em si mesma prática. Veremos como isso se dá em outro momento do trabalho.

Ou o homem age por determinação da razão, ou age movido pelos apetites do amor próprio que resulta no desejo geral à felicidade. A moral não pode basear-se na felicidade. A felicidade é um impulso geral na espécie humana que não carece de ser ordenada. Todos querem ser felizes. Entretanto, o cumprimento do dever moral não pode não ter como fundamento o desejo à felicidade. A virtude é assumida como o primeiro elemento central da filosofia moral. Se não podemos ter a felicidade como fundamento da moral no pensamento moral de Kant, então será que a felicidade é dispensada da filos ofia moral?

Agir por princípios morais não garante a felicidade como consequência. A felicidade é um desejo geral de todo homem. Faz parte de sua constituição sensível e não racional. A felicidade é um desejo natural e, por isso, tem relação com a natureza ( um conjunto de leis naturais) e não com a liberdade moral. A natureza é indiferente à lei moral porque é regida por leis naturais e não morais. Por isso, parece haver uma contradição, já que os agentes que tomaram o princípio moral como fundamento de suas ações não podem garantir por si mesmos que a felicidade seja a recompensa pela virtude (o esforço para o cumprimento do dever moral). A felicidade deve ser resultado da virtude e não o contrário. Se a felicidade tivesse precedência sobre a virtude, a moral estaria baseada em princípios relativos, dado que a felicidade de um não pode ser a felicidade do outro em função da indeterminação do conceito de felicidade. A felicidade poderá ser esperada apenas como resultado da virtude. A doutrina do sumo bem como objeto total da razão prática é compreendida como a junção entre virtude e felicidade. A virtude é o bem supremo e a felicidade como consequência da virtude é o bem completo. A junção de virtude com felicidade é o objeto total da razão prática conhecido como sumo bem.Segundo Kant [1788] (2002):

Ora, visto que a promoção do sumo bem, que contém esta conexão em seus conceitos, é um objeto aprioristicamente necessário de nossa vontade e interconecta-se inseparavelmente com a lei moral, a impossibilidade do primeiro caso tem que provar também a falsidade do segundo (2002, p.185).

A virtude deve ter a felicidade como recompensa, mas o homem não pode 
reunir liberdade (mundo moral) e natureza. Apenas aquele capaz de reunir mundo moral e mundo natural, é que pode realizar a junção entre virtude e felicidade, ou seja, pode realizar o sumo bem no mundo. Deus é, por isso, postulado (proposição teórica que não pode ser comprovada teoricamente) como o ser capaz de realizar o sumo bem no mundo.

Apenas quem assumiu como máxima mais fundamental de suas ações a lei moral é que pode esperar a felicidade como consequência da virtude. Apenas quem tomou a lei moral como centro de suas intenções mais verdadeiras é que pode esperar de Deus a realização do sumo bem no mundo. A religião é, por isso, a lei moral compreendida como mandamento divino. É religião natural e não positiva. A religião tem a ver com a prática e não com o conhecimento do que Deus seja em si mesmo. O conceito de religião racional não assume a existência objetiva de Deus. Ao contrário, será mostrado que o conceito racional de religião é concebido sem a necessidade de uma prova teórica da existência de Deus. Deus é uma ideia da razão que atende unicamente a necessidade subjetiva do homem de tomar as leis morais como mandamentos divinos a fim de que o seu ânimo seja disposto para o cumprimento do dever moral. Por isso, Herrero diz (1991):

Por que a fundamentação de Deus não se apoia na evidência, não existe entendimento, mas como sua fundamentação se baseia na razão prática, Deus é objeto de crença. Assim, a crença não ilumina propriamente o objeto, Deus, mas o próprio sujeito, o homem porquanto possibilita sua relação com o soberano bem (1991, p. 71).

Enquanto é objeto de crença (ou fé) para a filosofia moral de Kant, Deus atende a fins morais. Um conceito que é vazio (não tem um correspondente na experiência) para o campo teórico, ganha objetividade prática no campo moral. Deus é resultado de exigências morais. Como não existe nada na experiência que prove a realidade efetiva do sumo bem, e a impossibilidade dele é ao mesmo tempo o falseamento da lei moral, então é postulada a existência de Deus para que seja garantido (do ponto de vista moral) a possibilidade de realização efetiva do sumo bem, que é o objeto total da razão prática. A promoção do sumo bem é o fim para o qual todas as ações morais estão destinadas. Por isso,Kant[1793](2008) diz que: “ A moral conduz inevitavelmente é religião, pela qual se estende, fora do homem, á ideia de um legislador moral(...)(p.14)”. 
O segundo capítulo se deterá na aplicação do conceito de religião racional à religião positiva como critério supremo de interpretação dos símbolos religiosos. O problema fundamental da religião em A religião nos limites da simples razão [1793] (2008) é segundo Kant: “(...) tornar manifesta a relação da religião com a natureza humana, sujeita em parte a disposições boas e em parte a disposições más (...) (2008, p.18)". Kant chega à conclusão que o homem é propenso a tomar o princípio do amor próprio como fundamento de suas ações. Todos os homens inverteram a ordem do dever e ao invés de tomarem a lei moral como máxima fundamental de todas as ações, assumem máximas baseadas no amor próprio. É preciso, antes de tudo, restabelecer a pureza da lei moral em nós.

Assim como os homens inverteram o princípio universal das ações e tomaram o princípio do amor próprio, invertendo a ordem hierárquica entre os dois princípios, no fenômeno religioso não será diferente. Ao invés de iniciarem a formação de sua religião pelo estabelecimento da religião racional, estabelecem inadvertidamente, por uma fraqueza da natureza humana, religiões positivas no lugar da religião racional. A religião positiva começa pela fé histórica numa revelação, enquanto a religião racional atende a fins morais e tem em vista apenas a formação moral dos homens. As religiões positivas, nesse contexto, sofrem por meio do conceito racional de religião, uma crítica, onde tudo o que estiver contra a moral deve ser rejeitado como promanando de um falso princípio religioso.

A religião racional é a ideia (conceito puro da razão) de uma religião que ainda não se realizou na experiência. Por isso, Kant empreende uma crítica às religiões históricas no sentido de promover uma adequação entre religião racional e religião positiva. Sendo assim, para que uma religião seja considerada verdadeira (religião racional e moral) é necessário que ela se desvencilhe de tudo o que for histórico nela ou já tenha assumido o dever de fazê-lo. Em uma religião positiva ainda não aconteceu à superação dos símbolos pelas ideias morais. Depois disso, apenas a religião da razão deve permanecer como a religião moral e verdadeira. Segundo Herrero (1991): "A religião pura é sempre a meta a alcançar, diante da qual a história deve finalmente desaparecer (1991, p.184)". Nessa interação, apenas a religião racional deve permanecer e a religião positiva desaparecer. Segundo Kant [1793] (2008): 
Por conseguinte, embora (de acordo com a limitação inevitável da razão humana) uma fé histórica afecte como meio condutor a religião pura, contudo, com a consciência de que é apenas um meio condutor, e se esta fé, enquanto fé eclesial, trazconsigo um princípio de aproximação contínua à pura fé religiosa para, finalmente, poder prescindir desse meio condutor (...) (2008, p.121).

As religiões positivas para Kant devem sofrer uma crítica moral em função de sua constituição ser baseada na revelação. A revelação não está comprometida em si mesma com o desenvolvimento moral dos fiéis. Apenas se for referida ao seu critério (religião racional) é que elas podem promover a moralidade. Para Kant [1793] (2008), práticas contrárias à moral devem ser rejeitadas como falsas.

A relação que Kant estabelece entre a religião racional e as religiões positivas compreende a religião racional como uma esfera mais ampla da fé. Kant [1793] (2008) diz: "(...) visto que a revelação pode pelo menos compreender também em si a religião racional pura, ao passo que esta, ao invés, não pode conter o histórico da primeira, ser-me-á possível considerar aquela como uma esfera mais ampla da fé (...) (2008, p.21)". É mais ampla porque permanece com o fito a partir do qual toda religião positiva deve ser guiada. A meta da religião positiva é promover a moralidade dos fiéis. Enquanto promove a moralidade dos fiéis ela realiza a sua única função, que é tornar os homens melhores. Mas como a religião positiva é resultado de uma “limitação inevitável da natureza humana", é necessário que ela seja substituída e a religião racional seja estabelecida na forma de uma comunidade universal. As religiões positivas, no pensamento de Kant, têm a religião racional e, portanto, a moral, como critério de seu fazer. A sua missão é promover o sumo bem comunitário (junção a priori de virtude e felicidade numa comunidade regida por leis de virtude) no mundo. O fito principal de uma religião positiva é tornar os homens melhores.

No terceiro capítulo, faremos um balanço parcial da influência das teses kantianas expostas acima na filosofia da religião contemporânea. Inicialmente retomaremos a trajetória feita até então, pela qual buscamos mostrar que Kant acaba por reduzir o papel das religiões positivas ao tempo e ao espaço nos quais elas se fundam. Defenderemos que o viés de interpretação na filosofia da religião contemporânea sofreu uma alteração, passando de uma 
interpretação que passa de um julgamento com base em um conceito racional puro, como fez Kant, para uma interpretação da religião que inicia a partir dela mesma, com base na experiência da religião, método de interpretação iniciado por Schleiermacher.

Schleiermacher, por meio do seu livro Sobre a Religião: discursos aos seus menosprezadores eruditos [1799] (2000) não parte da moral como fez Kant. Parte da especificidade do religioso e nega qualquer intromissão da moral na determinação da essência da religião. Ao contrário, ele quer mostrar que a religião tem origem numa experiência com o Infinito. O homem é finito, mas na religião a sua experiência é com o Infinito. É através da experiência do finito com o Infinito (experiência da religião) que Schleiermacher inicia a sua investigação da religião e não através de um conceito natural de religião racional. A religião é uma experiência imediata com o Infinito e não pode ser mediada pela moral ou metafísica. Enquanto experiência passiva com o Infinito, a religião não tem nada haver com a ética.

Ainda mostraremos como o pensador John Hick, através de sua hipótese pluralista, empreendeu uma investigação das religiões positivas que não abandonasse as contribuições de Schleiermacher, e que visasse também à necessidade de um critério para a determinação da função da religião na vida das pessoas, como fez Kant. Apesar da mudança efetuada por Schleiermacher, onde o viés a priori da razão é substituído pela experiência do homem com o Infinito, Kant continua influenciando o pensamento contemporâneo, como será apresentado, em função de sua influência na hipótese pluralista de John Hick. 


\section{Capítulo 1 - O conceito racional de religião}

O conceito de religião no pensamento de Kant é resultado de sua filosofia moral. Para ele, a religião é consequência necessária da moral. De acordo com esta tese “(...) a moral aparece em sua majestade na religião (Herrero, 1991, p.74)". Essa majestade se fundamenta na ideia de que a religião é a consumação da liberdade moral. O conceito puro de religião não pode ser resultado de uma investigação que busca determiná-lo a partir do estudo de uma instituição religiosa. As instituições religiosas só podem ter alguma funcionalidade na medida em que promovem o desenvolvimento moral dos fiéis, ou que pelo menos suas doutrinas não estejam em desacordo com os princípios morais. Portanto, a religião é, para Kant, promanada da moral, é um conceito puro da razão, ou seja, um conceito que não pode ser dado na experiência. E como a lei moral é compreendida por Kant como tendo o seu fundamento na autonomia da razão prática pura frente aos impulsos sensíveis, o conceito de religião terá que ser a priori e, por isso, independente do modo como a religião histórica se apresenta aos sentidos do homem. O conceito de religião é um conceito puro da razão. Resulta de deveres morais. Por isso Kant [1788] (2002) afirma “(...) que a lei moral conduz (..) à religião, quer dizer, ao conhecimento de todos os nossos deveres como mandamentos divinos (...) (p.208)".

\subsection{A religião mediada pela moral}

Kant parte do princípio de que as ações morais se dão por determinações provindas unicamente da razão. Na busca pelo princípio moral, Kant pressupõe que, se há ações morais, todas elas devem ser determinadas por uma lei a priori da razão pura e não podem provir da representação de algum objeto da experiência. "A razão é capaz de determinar a vontade à ação" eis o que Kant quer provar em sua filosofia moral. Se há um mandamento moral, ele deve ser conectado imediatamente à vontade humana, ou seja, ele deve ser capaz de ser motivo para um ser que é racional e sensível. Na Fundamentação 
da metafísica dos costumes ${ }^{1}[1785]$, Kant encontrou a fórmula do imperativo moral na razão prática pura. Mas somente na Crítica da Razão Prática ${ }^{2}$ (1788) ele pôde desmembrar as consequências do estabelecimento do imperativo através da ideia ${ }^{3}$ do sumo bem ${ }^{4}$ moral. Com essa ideia (sumo bem), Kant queria resolver as cisões que resultaram da determinação da vontade pelo imperativo moral, na medida em que a lei moral é racional e o homem é racional e sensível. Por isso, é de suma importância encontrar os problemas que são resolvidos por Kant na ideia do sumo bem, depois de determinar o modo como esta ideia se torna necessária em sua filosofia moral, para depois chegarmos ao conceito de religião por meio dessa ideia. O imperativo moral é a forma universal ${ }^{5}$ do agir humano, e o sumo bem é o objeto ${ }^{6}$ necessário desse mesmo imperativo. A questão é compreender a lei moral e as consequências necessárias de seu objeto (sumo bem) para, a partir daí, entendermos a relação da moral com o conceito puro de religião. Portanto, o conceito de moral, sumo bem e religião terão importância capital no desenvolvimento de todo este capítulo.

O conceito de religião é resultado das exigências morais e não dos estatutos dogmáticos da religião estatutária. Kant diz [1798] (2008): “(...) que a religião jamais se possa fundar em estatutos (por mais elevada que seja a sua origem), é o que se depreende do próprio conceito de religião (2008, p.5051)". Depois disso, poderemos afirmar que o conceito puro de religião 1) Não resulta da análise empírica da religião, tal como ela se dá no fenômeno; 2) Que a religiosidade estatutária (fenomênica) não é totalmente desvalorizada, mas a sua função fica restrita aos ensinamentos morais e não aos conteúdos revelados. A religião não tem subsistência em si mesma. Ela tem a sua utilidade desde a moral. Por isso, Kant [1798] (2008) diz:

A religião não se distingue em ponto algum da moral quanto à

\footnotetext{
${ }^{1} \mathrm{Nas}$ próximas vezes que esse livro for citado usarei a sigla FMC.

${ }^{2} \mathrm{Nas}$ próximas vezes que esse livro for citado usarei a sigla CRPr.

${ }^{3}$ Ideias são conceitos necessários da razão que não podem achar nenhum correspondente na experiência. Por isso, a ideia é um conceito a priori.

${ }^{4} \mathrm{O}$ conceito de sumo bem nos conduzirá ao conceito de religião. Portanto, para este trabalho, o tal conceito é de suma importância.

${ }^{5}$ Para Kant a lei moral é universal, ou seja, é uma lei que provém da razão e não é um resultado das representações dos objetos da experiência.

${ }^{6}$ A lei moral nos diz o que devemos fazer e não o fim para o qual nossa ação se remete. O sumo bem como objeto da razão prática é um fim colocado pela razão como consequência da lei moral e não o contrário.
} 
matéria, i.e., quanto ao objecto, pois tem em geral a ver com deveres, mas distingue-se dela só formalmente, ou seja, é uma legislação da razão para proporcionar à moral, graças à ideia de Deus engendrada a partir desta, uma influência sobre a vontade humana para o cumprimento de todos os seus deveres (2008, p.10).

O conceito de religião não se distingue da moral, exceto quanto à forma, já que os deveres morais são tomados como mandamentos divinos na religião. A religião promana da moral e não da revelação. Isso significa que Kant não está transformando as duas esferas (religião e moral) numa só, mas que a religião só pode ser verdadeira se for resultado de exigências morais. Por isso Kant [1793] (2008) nos diz: “Mas, e isso é aqui o principal, tal ideia deriva da moral e não constitui o seu fundamento; é um fim cuja auto proposta pressupõe já princípios morais (2008, p.11)". É a formulação "lei moral como mandamento divino" que traz a ideia de Deus, conectada à do dever moral, com a finalidade de engendrar influência sobre a vontade humana para que a lei moral seja tomada como móbil da ação.

A moral nos mostra o que devemos fazer enquanto agentes livres. Para isso, diz Kant, nós não precisamos de Deus para sermos agentes morais. Chegar ao conceito de religião por essa via resulta, entretanto, da necessidade racional de responder a pergunta sobre o que podemos esperar. Desse modo, o entrelaçamento entre moral e religião visa responder duas perguntas fundamentais da razão humana (“o que devo fazer?" “o que posso esperar?").

No seu livro Crítica da Razão Pura ${ }^{8}$ (1785), Kant mostrou como podemos conhecer objetivamente as coisas do mundo, empreendendo uma crítica à razão que tinha por finalidade principal limitar o uso da razão teórica aos objetos provindos da experiência. Nessa crítica, era objetivo de Kant esclarecer o modo como é possível ter acesso aos objetos que podem ser conhecidos, frisando também que os objetos que não podem encontrar nenhum referente na experiência ficam indisponíveis para o conhecimento humano. O conceito de religião, tal como Kant o compreende, não dispensa os resultados que foram conquistados na CRP, mas se funda na afirmação de que os conceitos transcendentes (liberdade, Deus e imortalidade da alma) para a

\footnotetext{
7“Todo o interesse de minha razão (tanto especulativa quanto o prático) concentra-se nas três perguntas: 1.Que posso saber? 2. Que devo fazer? 3. Que me é permitido esperar?(CRP, 1999, p. 478)".

${ }^{8} \mathrm{Nas}$ próximas vezes que for citado esse livro será usada a sigla CRP.
} 
razão que conhece, são imanentes para a razão prática. O conceito de razão prática tem a ver com fundamentos determinantes da vontade e não (como na razão teórica) com objetos para o conhecermos tal como eles se dão na experiência. Kant encontra uma via de acesso a esses conceitos puros diferente da via da razão teórica. Com o conceito de razão prática, Kant consegue encontrar um caminho que faz com que os conceitos vazios para o âmbito do conhecimento (liberdade, Deus e imortalidade da alma) se tornem frutíferos no âmbito prático. A pergunta que nos cabe é: de que modo Kant concede aos conceitos vazios para a razão teórica objetividade prática? Como, por essa via, Kant chega ao conceito puro de religião? O campo prático de ação parte do pressuposto de que a lei moral na razão é o fundamento do dever e, por isso, não se trata de nos remetermos a algum objeto que possamos conhecer, mas de entender o que devemos fazer para agirmos moralmente. Somente por essa via, para Kant, é possível compreendermos a religião e a objetividade prática do conceito de Deus. Como a liberdade, imortalidade da alma e Deus são ideias que não podem ser comprovadas empiricamente, e como tais, não são objetos que possam ser conhecidos teoricamente, a via prático-moral é a única via de acesso a esses conceitos. Portanto, a religião só pode ser descoberta em sua verdadeira função a partir da moral. Mas como Kant compreende a moral? Como, pela via da moral, é possível chegar à religião?

\subsection{Imperativo categórico}

A filosofia moral de Kant parte de dois princípios fundamentais: o princípio do amor-próprio e o princípio moral (Heck, 1999). O princípio do amor próprio é um princípio subjetivo ${ }^{9}$ e o princípio moral é o princípio objetivo. Todos os móveis da vontade, que têm origem na representação de um objeto como fim da ação, não podem ser tomados como determinações de ações morais. O princípio moral tem origem na razão e é possível apenas se o homem pode ser determinado unicamente pela forma racional da lei moral. Se há uma lei moral capaz de determinar a vontade, então ela deve valer

\footnotetext{
9"Todos os princípios práticos materiais são, enquanto tais, no seu conjunto de uma e mesma espécie e incluem-se no princípio geral do amor de si ou da felicidade própria (2002, p. 37)".
} 
absolutamente. Por isso, deve valer para todos. Ao contrário, as ações fundadas no amor-próprio resultam em heteronomia para a razão e não podem causar uma ação moral.

Para Kant, a CRPr (1788) tem, entre outras funções, a função de impor limites à razão empiricamente condicionada. Essa função precisa ser esclarecida com base no princípio subjetivo do amor próprio da ação, que é a expressão máxima de uma razão empiricamente determinada. Como princípio, o amor-próprio toma a felicidade como substituta da determinação da lei moral. O amor-próprio toma a felicidade pessoal como determinação maior do arbítrio. Quem opta por máximas baseadas no amor-próprio pode decidir-se por regras práticas que colocam a felicidade ${ }^{10}$ como o único motivo do agir. Segundo José Heck (1999): “Em Kant, o amor-próprio adquire status de princípio porque a ele são referidos todos os possíveis princípios práticos, à exceção do princípio formal da moralidade (1999, p.172)”. Fazer de si mesmo o motivo determinante da vontade, deixando todos os outros motivos subordinados ao capricho do arbítrio, não promove uma ação moral.

O problema em colocar a felicidade como fundamento da moral é o fato do desejo à felicidade não poder ser preenchido com um conceito apropriado do que seja felicidade. O conceito de felicidade guarda uma indeterminação de tal modo que cada um encontra somente em si mesmo, e no seu desejo de ser feliz, o que seja felicidade, de maneira que um diz "felicidade é possuir bens" e outro diz o contrário "felicidade é dispensar os bens", sem que possamos ter um conceito definitivo. Se a felicidade fosse o fundamento do agir moral, teríamos que admitir que todos os princípios absolutos são impossíveis.

As inclinações produzidas pela representação de objetos empíricos podem até estar de acordo com a moral, mas não podem ser morais em si mesmas, já que para agir moralmente é necessário mais do que apenas legalidade. Agir por dever é mais que agir conforme ao dever, já que para agir "conforme" ao dever é requerida apenas a concordância da ação com a forma da lei moral, e agir por dever é pressuposto que a lei moral é tomada como fundamento da decisão interna do arbítrio. Agir "por dever" tem a ver com as intenções (uma legislação racional, portanto, interna), e a legalidade contenta-se com uma

\footnotetext{
${ }^{10}$ Segundo José Heck (1999): “Como princípio, o amor-próprio toma a felicidade pessoal como determinação maior do arbítrio. Quem opta por máximas, movido pelo amor-próprio enquanto princípio, pode decidir-se por regras práticas que têm por único e exclusivo fim a promoção da própria felicidade (1999, p.170)".
} 
legislação externa. Segundo Kant [1785] (2009): “(...) o dever é a necessidade de uma ação por respeito à lei (p.127)" e não por coerção de ordem externa ao agente. Cumprir um dever apenas porque está sofrendo coação externa tem a ver com legalidade e não com moralidade. A ciência moral kantiana estuda o fundamento dos deveres morais.

As leis práticas referem-se unicamente a forma de uma legislação universal. Como a experiência não pode fornecer nenhuma regra absoluta, e os princípios morais não podem basear-se no desejo geral à felicidade, então só nos resta à mera forma de uma lei em geral. Essa lei refere-se unicamente à vontade, sem computar os resultados que promanam dela ou fim. Segundo Kant [1788] (2002), referindo-se às regras empíricas: “(..) pois o fundamento determinante do arbítrio é nesse caso a representação de um objeto (p.36)". Uma lei moral deve abstrair de toda a matéria do querer e ficar apenas com a forma do querer em geral, já que “(...) leis práticas referem-se unicamente à vontade, sem consideração do que é realizado como causalidade da mesma (...)(Kant, 2002,p.35)". Princípios práticos materiais apoiam-se na representação de um objeto como fundamento determinante do arbítrio. A respeito disso Kant [1788](2002)diz: "Portanto ele é prático somente na medida em que a sensação de agrado que o sujeito espera da efetividade do objeto determina a faculdade de apetição (p.38)". Como leis práticas materiais elas não podem fundar uma regra absoluta e universal, então para que uma lei moral seja encontrada é necessário, ao invés de recorrermos à experiência, ascendermos à nossa razão, que se conter em si mesma uma lei moral será em si mesma prática sem o apoio da experiência.

Como o ser humano não é apenas racional suas inclinações produzidas pela afecção de objetos, fortalecidas pelo desejo geral à felicidade, querem determinar todas as ações. Mas se há uma lei prática, a vontade deverá ser capaz de dar a si mesma uma lei moral. Por isso Kant [1788] (2002): “Ora se se separa de uma lei toda a matéria, isto é, todo o objeto da vontade (enquanto fundamento determinante) dela não resta senão a simples forma de uma legislação universal (p.45)". Nesse sentido, ao passo que uma vontade absolutamente submetida à lei moral, onde o querer já concorda plenamente com a lei, é uma vontade santa (determinada pela lei da razão) a determinação da vontade de um ser racional, finito e sensível, é uma necessitação (Nötigung). Isso significa que o homem (enquanto é racional e sensível) 
precisa esforçar-se para o cumprimento do comando da lei moral. A sua vontade não é totalmente adequada ao comando da lei moral. Por isso, a razão tem que instituir a lei como imperativo categórico. Segundo Kant [1788] (2002): “A lei moral é santa (inflexível) e exige santidade moral. Embora toda perfeição moral que o homem pode alcançar seja sempre somente virtude(...) (p.206)". Só desse modo é possível dizer que a razão é prática em si mesma, já que ela conecta uma lei à vontade imperfeita do homem por meio de um imperativo moral. Logo, o imperativo categórico é uma proposição sintética $a$ priori, pois conecta, de forma absolutamente necessária, a vontade de todo ser racional e finito a uma lei universal da razão. Segundo Herrero(1996): “Assim, a lei moral assume duas formas diferentes: para a vontade de um ser perfeito, é lei de santidade, e para a vontade de um ser finito, é lei do dever(pflicht), de coação moral(p.30)".

É necessária uma filosofia moral para que o fundamento da moral, tal como Kant o pensou, seja necessário e universal. É filosofia pura, porque o princípio moral não é encontrado na observação dos dados da experiência, e sim em um âmbito distinto da experiência, que queira ultrapassar todas as culturas e práticas sociais, e encontre a lei moral apenas na razão em si mesma prática, ou seja, uma razão que seja capaz de determinar a vontade à ação. Se os princípios práticos que pressupõem um objeto empírico são os únicos a que nós temos acesso, então não há razão prática e a vontade não pode ser determinada moralmente pela razão. A razão prática é a capacidade de o homem agir em detrimento dos impulsos advindos da representação dos objetos da experiência. Ela é a capacidade de agirmos autonomamente e não em função de algum impulso produzido por nossas representações sensíveis. Agir com autonomia significa agir por nós mesmos e não em função de algo externo a nós. A vontade é capacidade de agir segundo a representação de leis que impomos a nós mesmos. A razão é uma faculdade que pertence a todos os homens. Se ela é capaz de determinar ações morais, sem a ajuda de impulsos sensíveis, somos nós mesmos que nos autodeterminamos na ação moral. Tomarmos como máxima a determinação da razão significa agirmos apenas no comando que colocamos para nós mesmos e sem a tutela de outrem. Segundo Kant [1788] (2002): "A autonomia da vontade é o único princípio de todas as leis morais e dos deveres conforme a elas: contrariamente a toda a heteronomia (p.55)". 
Contrariamente a toda a autonomia da vontade é a heteronomia da vontade, onde a vontade é determinada por algum móbil distinto da razão ou mesclado com ela. Nesse caso teríamos um imperativo hipotético, caracterizado pela condicional “se". Na proposição "Se quero ser médico, tenho que estudar medicina" percebemos um imperativo relativo a alguma coisa. A ordem é relativa ao fato de "se" queres ser médico "deves" estudar medicina. Ao contrário, o mandamento moral comanda sem relatividade. Não é necessário que uma condição se anteponha entre o que devo fazer e o que recolherei como resultado depois de feito. O mandamento moral é chamado, por isso, de imperativo categórico ${ }^{11}$. No imperativo hipotético temos as regras de destreza e conselhos de prudência. O imperativo categórico exprime uma ordem absoluta. A prudência é o meio mais eficaz de alcançar a felicidade. A destreza é a capacidade de encontrar o meio mais eficaz para atingir uma finalidade mais determinada. No caso da prudência, a razão indica de forma relativa o meio mais certo à felicidade, dado que não podemos ter certeza que aquilo que entendemos por felicidade seja de fato a felicidade que sentiremos. $\mathrm{Na}$ destreza, ao contrário, é indicado um meio mais eficaz para atingir a finalidade proposta, por exemplo, estudar medicina para ser médico. O comum entre ambos (prudência e destreza) é que o comando da razão é relativo a alguma coisa (se queres $\mathrm{X}$ tens que fazer $\mathrm{Y}$ ), por isso, tanto destreza quanto prudência são imperativos hipotéticos e não categóricos. Por isso, somente o imperativo categórico exprime o que devemos saber para agirmos moralmente. Vejamos o que Kant [1785] (2009) nos diz:

Ora, todos os imperativos mandam ou hipotética ou categoricamente. Aqueles representam a necessidade prática de uma ação como meio para conseguir uma outra coisa que se quer (ou pelo menos que é possível que se queira). O imperativo categórico seria aquele que representaria uma ação como objetivamente necessária por si mesma, sem referência a um outro fim (2009, p.189).

O imperativo categórico é uma ordem para seres racionais e finitos. Somente quem é racional e ao mesmo tempo sensível é capaz de desobedecer a sua própria razão. Para um ser que é santo, cuja vontade está totalmente

\footnotetext{
${ }^{11}$ Mais à frente mostraremos o conteúdo do imperativo categórico. Agora temos apenas que entender a diferença entre imperativo categórico e imperativo hipotético.
} 
determinada pela razão, a lei moral não poderia ser exprimida por meio de um imperativo. Uma ordem só faz sentido se houver a possibilidade de transgredi-la. Por isso, para os homens, a lei moral é um imperativo moral. Mas o que diz o imperativo categórico? Qual é o seu conteúdo?

Kant [1785] (2009) na FMC procura determinar qual é o conteúdo do imperativo. Se para acendermos à razão em si mesma pura, para pressupormos a vontade por ela determinada, é necessário que sejamos capazes de abstrair as máximas de todos os móveis empíricos, então só nos resta a forma. Para Kant [1795] (2009): “Os fins que um ser racional se propõe a seu bel-prazer como efeitos de sua ação (fins materiais) são, sem exceção, relativos (...) (2009, p.239)". O imperativo contém a lei moral e a necessidade da máxima de se conformar a essa lei. Por isso, o imperativo categórico é um juízo sintético a priori prático, dado que ele liga uma lei da razão à vontade. A lei moral não contém nenhuma condição que a limite, mas tem sua subsistência no caráter apriorístico de seu fundamento racional. Desse modo, se Kant [1785] (2009) está certo sobre a origem racional da moral, então resta-nos apenas a universalidade de uma lei em geral, cuja máxima deve ser conforme a ela. Os princípios práticos são formais quando fazemos abstração de todos os motivos materiais e abdicamos dos fins subjetivos para ficarmos apenas com a forma universal que ordena à máxima que seja conforme a ela: "Portanto, o imperativo categórico é um único apenas e, na verdade, este: age apenas segundo a máxima pela qual possas ao mesmo tempo querer que ela se torne uma lei universal (2009, p.215, grifo do autor)”.

Segundo Herrero (1991): “A necessidade de universalidade não constitui mais do que um critério formal para a ação (p.23)". A lei moral tem que se referir ao conhecimento humano para se tornar compreendida. Por isso, é necessário um mediador entre a forma da lei e as faculdades cognitivas do homem. Segundo Herrero (1991): “Esse mediador é o próprio entendimento através de seus conceitos puros. Essa dimensão do entendimento é representada pela faculdade de julgar, que para sua tarefa prática, não tem um esquema, mas sim um 'tipo' (p.23)”. O entendimento, no conhecimento teórico, através de categorias puras, reúne os dados sensíveis recebidos pela sensibilidade. Trata-se de um procedimento que necessariamente precisa de uma intuição. O procedimento realizado numa "típica da razão prática" é diferente. A aplicação da lei moral não pode ser feita por qualquer mediação 
de uma intuição sensível. Por isso, Kant [1788] (2002) usa o conceito de lei natural como tipo da forma da lei moral. A intenção de Kant (2002) é que “(...) aquilo que na regra foi dito universalmente (in abstracto) é aplicado em concreto a uma ação (p.108)”. No conhecimento teórico o conceito é adequado ao objeto (fenômeno) e, por isso predicado do objeto. Ao contrário, no conhecimento prático se trata apenas que ascender do sensível (um tipo) a conceitos morais por meio de uma analogia sem, contudo poder igualar um objeto (fenômeno) á própria lei moral (coisa em si). Temos apenas uma representação (tipo) que nos serve para aplicar a lei moral ao entendimento humano. Trata-se de um procedimento analógico, onde uma representação sensível distinta do que representa ganha uma utilidade prática enquanto representa. A lei moral não é lei natural, mas enquanto a lei natural serve de tipo da lei moral ela atende a necessidade humana de intuir conceitos puros para compreendê-lo. Por isso, segundo Kant [1793] (2008):

Quero aqui apenas observar de passagem que, na ascensão do sensível para o suprassensível (...) de nenhum modo se pode inferir, de acordo com a analogia, sobre o que pertence ao sensível, que ele deva atribuir-se igualmente ao suprassensível (e alargar assim o seu conceito); e isto, sem dúvida, pela razão inteiramente simples de que ir ia contra toda a analogia semelhante raciocínio (...) (p.75).

Iremos retornar ao assunto no segundo e terceiro capítulos, onde mostraremos que os conceitos morais, por uma necessidade humana, precisam de um apelo sensível para sua compreensão por seres racionais e finitos.

No tipo, a lei moral se torna uma lei natural para a faculdade de julgar. Daí o imperativo categórico: “(...) Age como se a máxima de tua ação devesse se tornar por tua vontade uma lei universal da natureza (1785/2009, p. 215, grifo do autor)". Esse tipo nos cede uma regra ${ }^{12}$ prática para julgarmos as ações morais, pelo menos do ponto de vista de sua conformidade.

Os outros dois tipos da lei moral pressupõem um fim na sua segunda fórmula e a autonomia da vontade na sua terceira fórmula. Na FMC [1785] (2009) Kant diz que a humanidade, considerada como fim em si mesma, não poderá ser tratada como meio. Como os fins subjetivos (como fins materiais) não estão entre os fins morais, já que eles são resultado de uma inclinação

\footnotetext{
${ }^{12}$ “Segundo essa regra, efetivamente, qualquer um ajuíza se as ações são moralmente boas ou más (2002, p.111)".
} 
empírica, não podem fornecer nenhuma regra absoluta. Por isso, na segunda formulação do imperativo categórico trata-se de um fim objetivo restritivo. Apenas há uma ordem restritiva que diz que não podemos tratar a humanidade como meio para qualquer outro fim. Por isso Kant [1785] diz "Esse princípio da humanidade e de toda natureza racional em geral enquanto fim em si mesmo (a qual é a condição restritiva suprema da liberdade(p.249)”. Enquanto é restritiva ela quer apenas limitar os fins subjetivos a não tomar nunca a humanidade como meio. Não temos aqui um dever positivo para com a humanidade, não nos oferece um dever positivo para com a humanidade, mas apenas diz que ela não deve ser tratada como meio. Na Religião...[1793] Kant avançará ao propor um dever da humanidade para com a humanidade. Veremos como isso se estabelece no segundo capítulo. O outro tipo do imperativo categórico é o da autonomia da vontade que refere-se a auto legislação do sujeito moral, que por força de sua razão, dá uma lei a si mesmo. Por isso Kant[1785](2009) diz que é “(...) em virtude da ideia da dignidade de um ser racional que não obedece a nenhuma lei senão àquela que ele dá a si mesmo(263-264)". Com relação aos três tipos, segundo Herrero (1996):

As três formulações do imperativo categórico (segundo a universalidade da lei natural, fim em si e autonomia)(...)possibilitam um desdobramento da lei moral fundamental abstrata. Propriamente nada acrescentam à lei, mas a expressam em sua totalidade, e tem em vista a sua aplicação prática (p.25-26).

A única regra da moralidade é, portanto, a exigência de universalidade das máximas.

A questão é saber se de fato isso que compreendemos como imperativo categórico pode ser provado, ou seja, se ele vigora na razão do ser racional e finito. O próprio Kant na FMC [1785] (2009) diz que o imperativo categórico pode ser vazio de conteúdo se não for provado que o imperativo de fato existe. Parece que a resposta definitiva de Kant à necessidade de provar a existência da lei moral foi iniciada na própria FMC [1785] (2009), mas só foi por meio da CRPr [1788] (2002) que Kant garantiu a objetividade da lei moral e, portanto, que a lei moral de fato pode ser conhecida na consciência do dever. Se isso for provado, é provado que a vontade é livre, garantindo assim a objetividade prática da liberdade. 


\subsection{Crítica da Razão prática e o Factum da razão}

A questão mais fundamental levantada pela Crítica da razão prática é se a razão é nela mesma prática. Ele quer saber se a razão pode, independente da experiência, representar leis puras que possam determinar a vontade do sujeito à ação, ou seja, Kant investiga a possibilidade da razão poder representar uma lei de determinação da vontade, sem que seja necessária a representação de um objeto que anteceda a lei moral da razão. Para deter a presunção de uma razão empiricamente afetada como fundamento da moral é que Kant procura demonstrar a existência da lei moral como fundamento do agir autônomo.

Portanto, a crítica da razão prática em geral tem a obrigação de deter a presunção da razão empiricamente condicionada de querer, ela só exclusivamente, fornecer o fundamento determinante da vontade (1788/2002, p.26).

Resta-nos saber de que modo Kant prova a efetividade da lei moral em todo ser racional. Kant havia tentado resolver esse problema na terceira seção da FMC $^{13}$. Entretanto, sua resposta definitiva será a dada na CRPr[1788], onde Kant nos faz a seguinte afirmação:

Pode-se denominar a consciência desta lei fundamental um factum da razão (...) que não é fundado sobre nenhuma intuição (...). Contudo, para considerar esta lei como inequivocamente dada, precisa-se observar que ela não é nenhum fato empírico, mas o único factum da razão pura, que deste modo se proclama como originariamente legislativa (sic volo, sic jubeo) $(1788 / 2002$, p. 53).

Mesmo sendo de suma importância a moralidade compreendida como factum da razão, Kant dispensou uma atenção secundária a essa questão,

\footnotetext{
${ }^{13}$ Alexandre Hahn (2010) diz que Kant fracassou em provar o imperativo categórico na terceira seção da FMC [1785] (2009). Entretanto, Júlio Esteves (2004) diz que não há um fracasso. O fato de Kant não ter assumido nenhum fracasso na terceira sessão da FMC[1785], concede a Esteves um dos indícios de que não é próprio falar de um fracasso.Com relação a esse problema, o presente trabalho não tem a intenção de expor essas posições, dado que a prova de Kant fornecida na CRPr [1788] será a que permanecerá nos seus escritos posteriores.
} 
dando margem para posições diversas na explicação desse conceito ${ }^{14}$. Percebemos dois aspectos negativos relativos ao factum da razão: 1) a ausência de uma intuição para sua prova; 2) a ausência de qualquer dado empírico. É que o fato não se apresenta sob a égide de algum confronto com a realidade fenomênica, mas se mostra apenas na razão. Para Höffe (2005), a moralidade deve ser compreendida como factum para vencer o ceticismo e comprovar sua validade universal. A solução de Kant parece ser demasiado simples. Ele dispensa provas teóricas que comprovem a efetividade da lei sobre nossa vontade. Não há como provar a existência do fato por meio de argumentos teóricos ou exemplos da experiência, mas, Kant [1788] (2002) afirma que tal fato é certo: “(...) a realidade objetiva da lei moral não pode ser provada por nenhuma dedução, por nenhum esforço da razão teórica, especulativa ou empiricamente apoiada (...) (2002, p.76)". De acordo com os argumentos de Kant, a consciência da lei moral como um factum da razão é suficiente para termos como certa e objetivamente válida. Se a lei moral é um factum da razão, a liberdade pode ser conhecida objetivamente, mesmo que só do ponto de vista prático.

\subsection{Liberdade}

No prefácio da Crítica da Razão Prática [1788] (2002), Kant reanuncia o caráter fundamental do conceito de liberdade para a totalidade do sistema da razão pura. A CRP pôde mostrar que não existe nenhum dado que mostre a impossibilidade da liberdade. Isso se constitui no limite que a razão especulativa pôde dizer a seu respeito, não lhe sendo possível sustentar qualquer proposição sintética acerca da liberdade, isto é, não sendo possível conhecer a liberdade. Se a liberdade não é passível de conhecimento experimental, já que a liberdade não pode ser um objeto intuído, o que dizer dela? Tendo como certo que para Kant a lei moral é provada por um factum, a liberdade fica comprovada no âmbito prático, ainda que permaneça um problema no âmbito teórico. Segundo Kant [1788] (2002), o problema da objetividade da lei moral (de que a razão é prática em si mesma) coincide com

\footnotetext{
${ }^{14}$ O artigo de Loparic (1995) intitulado “o fato da razão" e o artigo de Guido de Almeida (1999) intitulado "Crítica, dedução e fato da razão" deram início, no Brasil, a um debate sobre o real significado desse conceito. Como não é intenção do trabalho dar conta desse debate, preferi não entrar nos detalhes que o incitam.
} 
a necessidade da prova da liberdade, já que a liberdade “(...) constitui o fecho da abóboda de todo edifício de um sistema da razão pura (...) (p.4)”. Portanto, se for provado que a razão pura é prática em si mesma, é provado, ao mesmo tempo, que a liberdade é uma propriedade da vontade de todo ser racional em geral. Como, segundo a posição de Kant, a lei moral é provada por um factum, a liberdade é, junto com ela, provada objetivamente ${ }^{15}$. Então, podemos fazer duas afirmações: 1) Com a liberdade provada, fica aberto o caminho para a prova de outras ideias da razão (Deus e imortalidade da alma); 2) A liberdade é o caminho a partir do qual adentramos no âmbito da religião, já que a religião promana da moral e só podemos agir moralmente se formos livres para tal. Kant [1788] (2002) defende a tese da reciprocidade entre moral e liberdade. Ele diz que a justificação de um desses dois conceitos implica automaticamente na prova do outro conceito.

\subsubsection{Liberdade: uma prova teórica}

Liberdade pode ser entendida como uma espontaneidade absoluta. "Espontaneidade absoluta" no sentido de independer de uma causa natural anterior a ela. Ou a faculdade de iniciar uma série causal sem ser determinada por nenhuma causa antes dela. Desse modo, a liberdade não pertence ao conjunto de objetos dados na experiência. Ao contrário, a liberdade é um conceito sem referente no mundo fenomênico. Por isso, não pode receber nenhum conhecimento positivo no âmbito do conhecimento teórico. O conceito de liberdade parece contradizer uma das condições de possibilidade da experiência, a saber, o princípio da causalidade natural vigente no mundo natural. Nesse sentido, o conceito de liberdade apresenta-se como um problema para a razão especulativa, essa não podendo afirmar sua realidade objetiva, dado o fato de que não podemos conhecer um conceito (ideia) que não pode encontrar nada de correspondente na experiência. Liberdade e causalidade natural parecem excluir-se.

O termo "ideia" significa simples conceitos da razão não derivados da experiência. Uma ideia da razão é um conceito que não encontra nenhum correspondente na experiência. Não podemos provar teoricamente uma

\footnotetext{
${ }^{15}$ Kant[1788](2002) diz, referindo-se a realidade da liberdade diz: “(...) que sua realidade é provada por uma lei apodíctica da razão pura prática (...) (2002, p.4)”.
} 
causalidade que independa da série de causas, mas que ao mesmo tempo desencadeia uma série causal, sem ser causada por nenhuma causa anterior. Desta forma, temos que admitir, é impossível encontrarmos algo parecido com espontaneidade absoluta, ou seja, algo que independa das leis naturais na experiência. Nesse sentido, uma causalidade incondicionada coloca a razão diante de um conceito vazio, na medida em que a ele não pode ser aplicado nenhuma intuição. Na experiência, não encontramos nada comparado a uma causalidade livre e incondicionada. Sendo assim, Kant nega qualquer possibilidade de se ter um conhecimento positivo de qualquer ideia pura da razão.

Na dialética da CRP [1781] (1999), Kant desenvolve um estudo sobre a atividade da razão. A razão é a capacidade de relacionar juízos fazendo inferências. Nesse sentido, a dialética procura investigar o uso ilusório da razão, quando ela infere de juízos, conclusões que não podem ser comprovadas na experiência. Nesse sentido, a dialética é também uma lógica da ilusão. A razão empreende raciocínios que visam sínteses cada vez mais amplas com o intuito de conferir à razão uma direção. A razão raciocina com o fito de ligar (fazer unificações) do todo da experiência, dando uma explicação última por meio das ideias (conceitos que não podem ser comprovados na experiência). A razão quer uma explicação última de toda experiência por meio das ideias (Deus, imortalidade da alma e liberdade). As ideias da razão são aplicadas aos juízos do entendimento, assim como as categorias puras do entendimento são aplicadas no espaço e no tempo. Segundo Kant (Prolegômenos-1781) (1987):

Portanto, assim como o entendimento precisava das categorias para a experiência, de igual modo a razão contém em si o princípio das ideias; por elas entendo eu conceitos necessários cujo objecto, no entanto, não pode ser dado em nenhuma experiência (1987, p.111).

Tanto as ideias da razão quanto as categorias puras do entendimento visam uma unificação. O entendimento aplica suas categorias puras aos dados recebidos pela sensibilidade a fim de que esses dados dispersos no tempo e no espaço sejam reunidos no juízo.

A categoria pura de causalidade, por exemplo, é aplicada aos eventos como causas ou efeitos. O princípio que diz "para todo efeito tem que ter uma causa" leva à necessidade de admitir um estado anterior como sua causa. Mas como 
essa causa também é temporal, inicia-se uma série regressiva. Essa série só pode acabar se é possível pensarmos uma causa que não foi resultado de outra anteriormente dada. Aqui a razão estabelece a ideia do incondicionado, ou seja, uma causa que seja causa de si mesma e que para ela nada se pode achar de correspondente na natureza, mas não pode provar que tal causa de fato existe. A categoria de causa aplicada aos fenômenos diz que para todo efeito há uma causa. Não há um só evento no mundo natural que mostre uma causa que é causa de si mesma. A ideia de uma espontaneidade absoluta carece de comprovação empírica. Segundo Kant [1781] (CRP,1999): “A razão reserva para si somente a totalidade absoluta no uso dos conceitos do entendimento e procura conduzir à unidade sintética, que é pensada na categoria, até o absolutamente incondicionado (1999, p.247)".A razão não pode mostrar que suas ideias são verdadeiras no âmbito do conhecimento. Por isso, as ideias são apenas regulativas e não constitutivas do conhecimento teórico. A falácia da metafísica tradicional (antes de Kant) consiste em querer aplicar ideias puras da razão ao mundo sensível. A ideia de liberdade é vazia de sentido na medida em que não podemos afirmar nada a seu respeito no âmbito do conhecimento. Por isso, Kant na CRP, não pôde conferir positividade ao conhecimento da liberdade ${ }^{16}$.

\subsubsection{Liberdade: uma prova prática}

No âmbito da teoria, portanto, o que temos é um vazio, na medida em que liberdade não pode ser dada na experiência possível. Dessa forma, fala-se também de um abismo infinito, que se abre entre o que classificamos por fenômeno, que é a coisa tal como aparece para o sujeito e não nela mesma, e o que entendemos por númeno ou coisa em si mesma. Assim, fica determinado

16“Pois então se mostra logo que não é um fim teórico e sim prático que torna isso uma necessidade. Para a especulação, mesmo que tivéssemos sucesso nela, não faríamos nenhuma verdadeira aquisição de conhecimento da natureza e, em geral, em relação aos objetos que porventura nos possam ser dados, mas quando muito daríamos um grande passo do sensivelmente condicionado(onde já nos ocupa suficientemente permanecer junto a ele e percorrer diligentemente a cadeia de causas) ao suprassensível para completar e limitar o nosso conhecimento do lado das razões, embora sempre restasse não preenchido um infinito abismo entre aquele limite e o que conhecemos e tivéssemos dado mais atenção a uma valiosa mania de questionamento do que um sólido desejo de saber (Kant, $1788 / 2002$, p.88)". 
que, para falarmos de liberdade como uma causalidade que engendra uma série causal, teremos que nos livrar de qualquer intenção de alargar, no campo da teoria especulativa, nosso conhecimento, mas avançarmos na tentativa de mostrar a sua possibilidade prática. Essa ideia de uma causalidade livre, capaz de dar início a uma nova série de acontecimentos, não determinada anteriormente no tempo das séries causais, é pressuposto de uma causa que independa dos dados da experiência. Para defendermos a realidade do conceito de liberdade devemos pensar uma causa agindo livremente, aplicando-o a um ser agindo no mundo. Nesse sentido, a liberdade no âmbito prático deve ser uma propriedade da vontade humana, na medida em que a liberdade prática deve ser aplicada a um ser que age no mundo sensível. Liberdade pode ser entendida 1) como a capacidade de agir segundo uma lei que não seja deduzida da experiência ou das leis da natureza caracterizadas pela necessidade; 2) Como a capacidade de agir determinado unicamente pela razão. Nesse sentido, a ação moral inicia uma nova série de causas que não são promovidas naturalmente. As leis morais são a condição pela qual nos tornamos cientes da realidade da liberdade. Segundo Kant [1788] (2002):

Logo é a lei moral, da qual nos tornamos imediatamente conscientes (tão logo projetamos para nós as máximas da vontade), que se oferece primeiramente a nós e que, na medida em que a razão a apresenta como fundamento determinante sem nenhuma condição sensível preponderante, antes, totalmente independentes delas, conduz diretamente ao conceito de liberdade (2002, p.50).

Desse modo, o conhecimento prático ${ }^{17}$ obtém um sucesso que o conhecimento teórico não pôde. A liberdade é uma propriedade da vontade humana enquanto é determinada pela lei moral. Autonomia se diz da vontade que age por si mesma e é independente das leis naturais e, por conseguinte, de inclinações e impulsos sensoriais em seu sentido negativo, isto é, é a capacidade de agir determinado pela razão em seu sentido positivo ${ }^{18}$. Portanto, a lei moral não se funda em inclinações subjetivas, porque as leis práticas devem ter validade objetiva, já que devem valer para todo ser racional. Uma

170 conhecimento prático tem a ver com fundamentos determinantes da vontade e não com o conhecimento dos objetos que podem ser dados na experiência como no uso teórico da razão.

18 "Mas aquela independência é liberdade em sentido negativo, porém esta legislação própria da razão pura e, enquanto tal, razão prática, é liberdade em sentido positivo (1788/2002, p. 55)”. 
representação independente de todo sentimento, mas também de toda matéria e afecção advinda da sensibilidade, só pode ser fornecida pela razão. O sujeito é aqui capaz de produzir ações segundo princípios da razão prática. A lei moral dá ao conceito de liberdade realidade objetiva, mesmo que só no âmbito prático. Assim, a possibilidade de uma lei moral universal tem como fundamento a liberdade. A vontade que não impõe a si mesma o preceito da ação moral pode ser dita heterônima e, portanto, não livre. Ou seja, ela é determinada por motivos externos a ela mesma e não pela lei da liberdade. Desta forma, a vontade do sujeito se prende à matéria do querer ou objeto do desejo.

(...) o fundamento determinante do arbítrio é nesse caso a representação do objeto, e é aquela representação com o sujeito pela qual a faculdade de apetição é determinada à efetivação do mesmo (Kant, 1788/2002, p. 36).

O que Kant quer dizer é que é necessário ser livre para agir moralmente. Isso não significa, entretanto, que a liberdade é provada antes da lei moral. Como para Kant a lei moral foi provada por um factum, então a liberdade é provada como condição de possibilidade para agirmos moralmente, e assim, uma ideia que era vazia para a razão teórica, ganha objetividade prática para o conhecimento prático. Ficaria assim provado que a vontade é livre, que é possível agir moralmente porque somente um ser que, apesar de ser racional e sensível, pode agir sem ser determinado por nada de externo a si mesmo, pode agir com liberdade no mundo.

Mas como a lei moral pode tornar-se motivo para a vontade de seres racionais e sensíveis? Kant responde essa questão através do sentimento moral.

\subsection{Sentimento moral}

No sentido kantiano, compreender a razão prática a partir de um entrelaçamento entre sentimento, que é produzido por um fenômeno externo ao sujeito, seria o mesmo que dizer que não há moralidade, dado o fato de que a moral está intrinsecamente ligada à universalidade e uma lei de ação baseada na subjetividade só poderia fornecer uma lei relativa. Universalidade esta que não pode ser computada entre as ações promovidas por um 
sentimento. A moral consiste na convicção de que a vontade pode ser determinada pela razão sem a mediação dos sentimentos. Se a vontade for determinada conforme a lei moral, entretanto, mediada por um sentimento, até podemos falar de uma ação conforme à lei moral, mas destituída de sentido verdadeiramente moral. Kant quer mostrar que o querer precisa submeter-se à objetividade da lei prática pura. Nesse sentido, trata-se de pensar a moral, não em vista do prazer ou desprazer causado por um sentimento subjetivo, mas fundada unicamente na razão. Toda ação precisa necessariamente de um motivo, e com isso Kant concorda, mas ele avança no sentido de dizer que a razão pode infundir um motivo para a moralidade. Para ele, a lei moral precisa causar um efeito suficiente na natureza sensível do homem a fim de que a moralidade se efetive de fato engendrando um motivo suficiente para a ação. O fundamento determinante da vontade precisa e deve ser independente da experiência. A experiência fornece leis relativas. A lei da razão ou lei da moralidade fornece uma lei que vale para todo o ser racional. Se a vontade precisa de um motivo de determinação, e para agir moralmente ela deve encontrar um motivo cuja origem seja puramente racional, então:

(...) não resta senão apenas determinar cuidadosamente de que modo a lei moral torna-se motivo e, na medida em que o é, que coisa acontece à faculdade de apetição humana enquanto efeito daquele fundamento determinante sobre a mesma lei (1788/2002, p.116).

Como é possível que uma lei racional seja capaz de determinar o ânimo de um ser racional e imperfeito é o que Kant quer resolver ao introduzir a sua teoria do sentimento moral. Motivo (Triebfeder) não é compreendido aqui como "mola propulsora" (fundamento objetivo da apetência) em sua distinção, expressa na Fundamentação da metafísica dos costumes [1785] (2009), com o termo alemão Bewegungsgrund (razão movente), como um "fundamento objetivo do querer", sendo que apenas o último era chamado de "motivo". Segundo Valério Rohden ${ }^{19}$, Triebfeder passa, pois, a identificar-se, na Crítica da razão prática com Bewegungsgrund, tomando ambos o sentido de um fundamento determinante subjetivo da ação. Triebfeder pode significar tanto motivos sensíveis, quanto motivos morais. O motivo é sensível se é determinado pela representação de um objeto (inclinação) e moral se for, 
como é o sentimento moral, determinado pela lei moral.Isso não significa que o motivo gerado pela lei moral não seja sensível, mas que se esse motivo é moral significa que a lei moral tem primazia sobre ele.

A oposição da lei moral aos impulsos sensíveis é de imediato o fundamento de um dano à parte sensível do homem. Esse dano é ele mesmo um sentimento. A lei racional se impõe de tal modo que obriga que os impulsos, inclinações e sentimentos sejam suprimidos enquanto fundamentos do agir para que ela seja o único motor de determinação da vontade. Todas as inclinações sensíveis, inclusive o desejo de felicidade, sofrem aqui um dano. Por isso, a felicidade, entendida como o máximo do amor próprio, não pode ser o fundamento da moral. Mas a moral desde seu horizonte puramente racional já é a exigência de que o amor próprio como critério do agir moral deva ser suprimido. A lei moral abate a presunção de fazer da máxima do amor de si com sua pretensão em se fazer o fundamento da moralidade “(...) na medida em que todas as exigências de auto-estima que precedem a concordância com a lei moral são nulas e totalmente ilegítimas (Kant, 1788/2002, p.119)".

Além do sentido negativo que lei moral tem na sua relação com a sensibilidade humana, produz também um sentimento positivo. Na medida em que a lei moral se impõe a fim de que as máximas sejam submetidas à exigência de universalidade, ela gera um sentimento de respeito que é favorável à determinação da vontade pela lei moral. Por isso Kant [1788] (2002) afirma: "Pois toda redução de obstáculos de uma atividade é promoção dessa mesma atividade (p.128)". Ao humilhar e abater a natureza sensível do homem, a representação ideal da perfeição moral se torna o objeto de máximo respeito, fazendo com que seja também o fundamento de um sentimento positivo. O homem que toma a lei moral como motivo a toma como máxima do agir por respeito ao dever que é mandado. Por isso, Kant nos afirma: “(...) pela razão somos conscientes de uma lei à qual todas as máximas são submetidas (1788/2002, p.71)". As nossas máximas guardam os nossos motivos. Nesse sentido, a lei moral deve poder fazer com que os nossos motivos sejam convertidos pela lei moral numa unidade primordial que reúne o múltiplo do desejo à unidade da motivação moral.

(...) para subordinar o múltiplo da intuição (sensível) a uma consciência a priori, e sim somente para submeter o múltiplo das apetições à unidade da consciência de uma razão prática, ou de uma vontade pura a priori, que ordena na lei moral 
(Kant, 1788/2002, p.104).

Toda ação necessita de um motivo, mas o motivo promovido pela lei moral não é produzido por representações de objetos que são dados na experiência. A lei exige que o sujeito a pratique engendrando um motivo suficiente. Todavia, esse motivo não é resultado de uma representação sensível que se apresenta na experiência e que por isso se baseia numa inclinação subjetiva do sujeito que ao representar o objeto se inclina para a efetivação do mesmo. O motivo aqui apresentado, ao contrário de um motivo produzido pelos objetos da experiência, é resultado do efeito da lei moral sobre a natureza sensível do homem. De certo modo, trata-se de uma limitação à natureza sensível do homem ${ }^{20}$. O homem quer fazer de seus próprios princípios subjetivos o fundamento do agir moral. A lei moral exige que a máxima seja submetida à objetividade da lei. Desse modo, o que a lei moral quer é deter a presunção de se fazer de sua própria inclinação empírica o fundamento determinante da vontade. Segundo José Heck (1999):

Selbstliebe é amor-próprio benevolente em extremo para consigo mesmo, propenso a cristalizar-se em arrogante presunção tão logo se torne complacente consigo próprio. Enquanto o amor de si consiste em colocar o amor-próprio acima de quaisquer preferências, a presunção consiste na alucinante escolha de objetivos meramente subjetivos como fins objetivos que excluam qualquer referência objetiva superior (1999, p.170).

O efeito da lei moral na natureza sensível do homem o humilha diante da perfeição da lei moral. A ação da lei, no primeiro momento, é negativa, na medida em que a lei moral causa um descontentamento no homem consigo próprio. "Portanto, a lei moral inevitavelmente humilha todo homem na medida em que ele compara com ela a propensão sensível de sua natureza (1788/2002, p.121)". O homem tem a propensão de fazer do amor que tem a si próprio o fundamento determinante da vontade. A lei moral anula essa prepotência, causando um abatimento que causa humilhação.

Essa propensão a fazer a si mesmo, com base nos fundamentos determinantes subjetivos de seu arbítrio, o fundamento determinante objetivo da vontade pode ser chamado amor de si,

20“Ora, essa limitação promove um efeito sobre o sentimento e produz uma sensação de desprazer, que pode ser conhecida a priori a partir da lei moral (Kant, 2002, p.117)". 
o qual, se se converte em legislativo e em princípio prático incondicionado, pode ser chamado de presunção (Kant, 2002, p.120).

A lei moral resiste à propensão de se fazer do amor de si o fundamento determinante da vontade à lei incondicionada de ação moral. A lei moral não é de ordem sensível, mas de ordem inteligível e por isso causa um efeito, que no primeiro momento, é negativo e coloca em evidência as imperfeições dos princípios subjetivos e, no segundo momento, respeito pela perfeição da lei moral.

Entretanto, a lei moral não só humilha, causando um sentimento que é de ordem negativa, mas também gera um sentimento de admiração ou afeto de estupefação, a saber, o sentimento de respeito, como bem apontou Howard Caygill (2000). A razão promove um sentimento de respeito, conhecido $a$ priori. O respeito pela lei moral é um fundamento determinante subjetivo (motivo) do reconhecimento do sujeito à lei moral. Nas palavras de Kant [1788] (2002):

(...) do mesmo modo ele é também fundamento determinante subjetivo, Isto é, motivo para ação na medida em que ela tem influência sobre a moralidade do sujeito e provoca um sentimento que é favorável à influência da lei sobre a vontade (2002, p.122).

A lei moral, enquanto uma lei do sujeito da razão prática e por isso pertencente a uma ordem inteligível das coisas humilha a natureza sensível desse mesmo sujeito, ao subjugar pela ruptura, todas as inclinações. Com isso, não queremos dizer que há uma ruptura com as inclinações. Se acontece uma ruptura é apenas com vista ao comando que a razão deve exercer sobre as inclinações e não a extirpação delas ${ }^{21}$. A lei moral também gera um sentimento positivo, a saber, o sentimento moral de respeito. Ela provoca um sentimento que é favorável ao cumprimento da pura determinação da lei sobre a vontade. Na medida em que todo sentimento é sensível e a determinação do sentimento moral precisa ser encontrada na pura forma da lei moral. Segundo Kant [1788]

21 Segundo Kant [1793] (2008): "(..) o primeiro bem verdadeiro que o homem pode fazer é sair do mal, o qual não se deve buscar nas inclinações, mas na máxima pervertida e, portanto, na própria liberdade. Aquelas dificultam somente a execução da máxima boa oposta; o mal genuíno, porém, consiste em não querer resistir às inclinações quando incitam à transgressão, e esta disposição de ânimo é, em rigor, o verdadeiro inimigo (p.64)". 
(2002), não podemos sentir respeito por coisas, mas unicamente por pessoas. As coisas podem despertar inclinação, mas nunca respeito. Quando nos colocamos diante de um homem, que mesmo sem ter posses ou glórias, é honesto, integro e fiel, nos curvamos para reverenciar a perfeição da lei moral. O seu exemplo mostra-nos uma lei que aniquila a nossa presunção através de sua perfeição e aí só me resta respeitá-lo, quer eu queira ou não. Podemos até nos abster do respeito publicamente, mas nunca internamente ${ }^{22}$. Vejamos o que Kant [1788] (2002) nos diz:

Aquilo cuja representação, enquanto fundamento determinante de nossa vontade humilha-nos em nossa autoconsciência, enquanto é positivo e é fundamento determinante desperta por si respeito. Logo, a lei moral é também subjetivamente um fundamento de respeito (2002, p.121).

A lei moral produz o motivo moral através do sentimento de respeito. O sentimento de respeito é o efeito da lei moral sobre a sensibilidade do homem. Segundo Loparic (1995): “Um aspecto desse efeito dinâmico da lei em nós são os conflitos, a saber, os conflitos entre o sentimento de respeito e os sentimentos de prazer e de dor enquanto condições subjetivas das ações da vontade (p.37)". Enquanto uma vontade santa se autodetermina adequadamente de acordo com a lei moral, uma vontade humana a recebe como necessitação porque a lei moral é imperativo para uma vontade imperfeita. Não podemos entender o sentimento moral como o fundamento da lei moral, mas como sendo de tal modo ligado à lei moral que é a própria moralidade considerada subjetivamente como motivo. A lei moral, por abater toda a presunção do amor de si, confere autoridade à lei que assume influência sobre a sensibilidade. O respeito seria um efeito sobre a sensibilidade. Portanto, é preciso que seja entendido que a sensibilidade não funda a lei moral. O que está em questão na concepção de sentimento moral em Kant é que seja encontrado um sentimento que faça frente aos impulsos do amor-próprio. Segundo Loparic (1995): “O sentimento de dever urge agir de acordo com a lei e em oposição às injunções dos sentimentos de prazer e desprazer (pg.41)".

Kant colocou a vontade moralmente determinada na razão prática. 
Entretanto, os homens são racionais e sensíveis, por isso foi necessário mostrar o modo como o dever gera respeito pela lei moral a fim de que a razão encontre um sentimento propício para a moralidade das disposições. Entretanto, com o respeito, não podemos imaginar que já decidimos pela lei moral como móbil da ação. O que fica garantido com o sentimento de respeito é que na sensibilidade humana podemos encontrar um sentimento favorável à determinação da vontade pelo imperativo categórico. Os homens são, por isso, incapazes de agir moralmente, sem que um esforço seja empreendido. Por isso, a lei moral é um dever para seres racionais e finitos. Não agimos moralmente como se nossa vontade fosse adequada ao mandamento moral. Kant, referindo-se ao homem, diz: “(...) o seu estado moral, em que ele pode cada vez encontrar-se, é o da virtude, isto é, de disposição moral em luta e não de santidade, na pretensa posse de uma completa pureza das disposições da vontade (1788/2002, p.137)". O problema consiste no fato de, enquanto seres racionais e finitos não podermos ser plenamente morais. "Mas a plena conformidade da vontade à lei moral é santidade, uma perfeição da qual nenhum ente racional do mundo sensorial é capaz em nenhum momento de sua existência (Kant, 1788/2002, p.198)”. A lei diz que devemos ser perfeitos e nós, ao contrário, somos imperfeitos. Por isso é que, segundo Kant [1788] (2002), temos que empreender um esforço para agirmos moralmente. Kant nos informa em sua Antropologia do ponto de vista pragmático: “(...) virtude é a força moral no cumprimento do seu dever, que jamais se tornará hábito, devendo provir, sempre de forma inteiramente nova e original, da maneira de pensar (Kant, 1798/2006, p.460)". 


\subsection{Sumo bem ${ }^{23}$ e o conceito de religião}

O conceito de religião pura no pensamento de Kant é resultado do dever moral. O problema é que a lei moral é racional e nós (homens) somos racionais e finitos. Foi mostrado que a lei abate a presunção de fazermos de nossos motivos particulares o fundamento de nosso agir moral. Entretanto, foi dito também que a lei gera nos homens respeito, dado que não somos capazes de cumprir totalmente o que o imperativo categórico ordena. Por isso, o nosso estado moral é o de virtude e não o de uma suposta posse da santidade da vontade. Se isso for verdade, teremos que confessar que a liberdade plena de nossa vontade é apenas uma ideia que carece de realidade. Mas como nos foi provado que a liberdade é uma propriedade de nossa vontade, podemos afirmar que é nosso dever fazer com que nossas ações no mundo sejam de fato livres. Mas a ordem moral é absoluta e sem restrições e o homem é incapaz de cumprir tudo o que lhe é ordenado. Parece que se abre uma cisão no homem. De um lado, ele é racional e, do outro, ele é sensível. Em sua parte racional, ele é um ser moral, mas em sua parte sensível é um ser natural. Em sua parte natural, ele deseja ser feliz e pertence à natureza. Exatamente por isso a felicidade não pode ser o fundamento do dever, já que não podemos ordenar algo que já queremos. Os humanos são carentes e querem ser felizes. Mas o seu desejo de ser feliz está ligado a sua parte sensível. A sua parte sensível o faz um ser de natureza sob leis naturais. A sua parte racional o torna membro de um possível mundo inteligível ou moral. Essa cisão entre natureza sensível e racional é parte constitutiva disso que é o homem. A lei moral é dever porque o humano não é santo como Deus. Se a lei moral transporta-nos para

23Sobre o sumo bem existem posições diversas. Júlio Esteves (1998) mostrou o papel do sumo bem na filosofia prática de Kant, enfatizando o papel desse conceito para a moral. Segundo ele (1998), se o sumo bem não for possível a lei moral também é impossível. Ele diz que “(...) na verdade, o sumo bem é aquilo que o imperativo categórico em última análise ordena do ser racional finito (p.23)". Em vista disso ele conclui o seguinte: "Assim, abandonar os esforços em vista do sumo bem equivale a abandonar aquela máxima fundamental, equivale a recusar obediência à lei moral. Assim, o que resta a fazer é restituir a crença na possibilidade de alcançar aquilo que é posto como o fim último e irrenunciável de uma vontade moralmente determinada, a saber, a felicidade e a virtude conectadas no conceito do sumo bem (1998, p.32)". A crença(fé racional) é a esperança de alcançar "aquilo que é posto como fim último(sumo bem) de uma vontade moralmente determinada. Concordando com Esteves está Herrero(1991): “O dever de promover o Soberano bem resulta única e exclusivamente da lei moral. O fim término da razão prática é consequência da lei moral (1991, p.73)". Herrero(1991) chega a dizer que: "A liberdade deve ser, deve encontrar sua plenitude na realização do Soberano bem no mundo (72)." 
um mundo inteligível e nós somos também sensíveis, como fazer para reconciliar liberdade e natureza? Kant, na CRP [1781] (1999), nos diz que não há nenhum problema em pensarmos liberdade e natureza como parte de um mesmo fenômeno, já que o fenômeno não é a coisa em si. Podemos pensar que mesmo que os eventos do mundo aconteçam sob leis naturais, não há nada que impeça que sua causa seja de outra ordem. Ainda que a ação aconteça no mundo natural, ela poderia ser determinada por uma lei de liberdade, já que as coisas do mundo natural são fenômenos e não númenos (coisas em si). As leis da natureza são naturais, e as leis morais são leis de liberdade. Parece haver uma incoerência no princípio moral. A razão busca a unificação de liberdade e natureza. Do que foi dito, é inevitável uma dialética da razão prática. Sua dialética consiste no fato de que, o praticamente condicionado (homens que desejam a felicidade e que são racionais e finitos) procura o incondicionado como consequência necessária da determinação da vontade humana pela lei moral. O incondicionado para a razão prática é o sumo bem como objeto total da razão (fim terminal). O sumo bem é a união entre moralidade e felicidade como fim a priori imposto pela razão através da lei moral.

Já foi dito que a felicidade não pode ser o fundamento da moralidade. E que, portanto, a lei moral é o único fundamento determinante da vontade. O sumo bem (reunião a priori de moralidade e felicidade) deverá ser consequência da determinação da lei moral sobre a vontade e não o contrário. Nenhum fim empírico pode ser causa de uma ação moral. A lei moral subsiste por si e o homem, para estar cônscio de seu dever, não precisa de um fim. A lei determina a vontade sem que seja necessário um fim. No entanto, talvez seja necessário um fim como procedência das exigências morais. Segundo Kant (1793/2008):

Mas embora a Moral não precise, em prol de si própria, de nenhuma representação de fim que tenha de preceder a determinação da vontade, pode ser que mesmo assim tenha uma referência necessária a um tal fim, a saber, não como ao fundamento, mas como às necessárias consequências das máximas que são adoptadas em conformidade com as leis. - É que sem qualquer relação de fim não pode ter lugar no homem nenhuma determinação da vontade, pois tal determinação não se pode dar sem algum efeito, cuja representação tem de se poder admitir, se não como fundamento de determinação do arbítrio e como fim prévio no propósito, decerto como consequência da determinação do arbítrio pela lei em ordem a um fim (finis in consequentiamveniens); sem este, um arbítrio 
que não acrescente no pensamento à acção intentada algum objecto determinado objectiva ou subjectivamente (objecto que ele tem ou deveria ter), sabe porventura como, mas não para onde tem de agir, não pode bastar-se a si mesmo (2008, p.10$11)$.

O fim moral (sumo bem) não é um adereço à determinação da vontade pela lei. É em função das consequências das máximas em conformidade com a lei que nos é posto um fim pela razão. Entretanto, é dito acima também que "sem relação de fim não pode ter lugar no homem nenhuma determinação da vontade, pois tal determinação não se dá sem algum efeito". O efeito deve ser admitido como consequência e não como fundamento de determinação do arbítrio. Sem este fim até podemos saber o que devemos fazer, mas não poderemos saber para onde queremos ir. A determinação da máxima pelo imperativo categórico coloca diante do agente moral um objeto total da vontade determinada moralmente. Segundo Júlio Esteves (1998): "Pois, na verdade, o sumo bem é aquilo que o imperativo categórico em última análise ordena do ser racional finito. Eis por que Kant pode dizer que "é a priori moralmente necessário produzir o sumo bem pela liberdade da vontade (1788/2002, p.151)". Uma lei que não tem o seu objeto não conhece o seu destino. Por isso, o conceito de sumo bem como objeto total da razão prática é necessário para a determinação da vontade (não como fundamento), mas com o fito de direcionar os nossos esforços morais, revelando o fim moral que é posto no próprio imperativo categórico. O objeto da razão prática é o fim que é posto na própria lei.

Já na FMC [1785] (2009), Kant afirma que entre os tipos possíveis da lei moral como imperativo categórico, podemos encontrar a seguinte fórmula: $\mathrm{O}$ imperativo prático será, portanto, o seguinte: “Age de tal maneira que tomes a humanidade, tanto em sua pessoa, quanto na pessoa de qualquer outro, sempre ao mesmo tempo como fim, nunca meramente como meio (2009, p.244245) (grifo do autor)". Entretanto, o fim que é colocado como imperativo é um fim que é por si mesmo subsistente. A pessoa como fim em si mesmo é a pessoa humana. E esta, como fim em si mesma, nunca poderá ser tratada como meio para nenhum outro fim. Nem o agente da ação, nem aquele que sofre a ação, poderão ser tratados como meio, mas apenas como fim. Sem necessidade de nenhum meio de passagem para atingi-lo, o fim que é fim em si mesmo, não resulta de alguma representação empírica, mas está contido no próprio 
imperativo categórico. Portanto, para que o mandamento moral fique mais claro à consciência humana, Kant deriva, analiticamente, outras possibilidades de expressar a própria fórmula do imperativo categórico. Tais fórmulas expressam a concordância da lei moral com a razão prática. Desse modo, o fim que é posto na fórmula do imperativo, que manda tratar a pessoa humana como fim em si mesma, não apresenta esse fim como objeto total da razão prática, mas sim como condição de uma vontade moralmente determinada pela lei moral. Nesse sentido, a fórmula do imperativo em questão é tão formal como a ideia de uma razão prática que comanda a vontade sem referência a um fim como resultado.

O sumo bem é a ideia de reunião entre virtude e felicidade, unidade que só pode ser pensada sinteticamente, mas que não pode ser garantida pela experiência. O sumo bem é, portanto, um objeto de fé, e Deus é a ideia de que esse objeto (sumo bem) pode ser realizado. No campo prático moral, a necessidade subjetiva de ter que pressupor uma causa originária da natureza que é capaz de proporcionar a felicidade na medida em que os homens se fazem dignos dela, levou Kant aos postulados. O postulado da existência de Deus, por exemplo, é necessário para o estabelecimento do sumo bem. Segundo Kant [1793] (2008):

(...) a ideia de um bem supremo no mundo, para cuja
possibilidade devemos supor um Ser superior, moral,
santíssimo e omnipotente, o único que pode unir os dois
elementos desse bem supremo; mas esta ideia (considerada
praticamente) não é vazia, porque alivia a nossa natural
necessidade de pensar um fim último qualquer que possa
ser justificado pela razão para todo o nosso fazer e deixar
tomado no seu todo, necessidade que seria, aliás, um
obstáculo para a decisão moral. Mas, e isso é aqui o
principal, tal ideia deriva da moral e não constitui o seu
fundamento; é um fim cuja autoproposta pressupõe já
princípios morais (grifo meu) (2008, p.13).

Não que a lei moral precise da ideia de Deus para encontrar seu fundamento, mas aquilo que a própria lei moral coloca para ser realizado (o sumo bem como o seu objeto total) deve ser possível. Nisso consiste a essência da fé racional, a saber, que uma pressuposição subjetiva (a pressuposição de que o objeto da razão prática seja possível), por causa de nossa carência subjetiva, se torne objetiva (pelo menos do ponto de vista moral) para o agente que se faz digno da felicidade. A ideia de Deus não é 
vazia, mas atende a uma carência subjetiva, de ter que sempre pensar para o condicionado o incondicionado. Entretanto, a reunião entre liberdade e natureza, condição necessária para o estabelecimento do sumo bem, não pode ser encontrado na experiência. Apenas a ideia de Deus nos permite pensar (pelo menos como possível) a reunião de virtude e felicidade num mesmo conceito. Por isso Kant [1793] (2008): “(...) só assim se pode garantir realidade objectiva prática à combinação da finalidade pela liberdade com a finalidade da natureza, combinação de que não podemos prescindir (p.13)". Herrero (1991) nos informa: "Mas se o homem deve realizar o sumo bem no mundo, tal como lhe é prescrito pela lei moral, tem que aceitar a possibilidade, conforme lhe mostra a sua razão, isto é, a existência de Deus (p.69)".

A fé racional na ideia de Deus não pode ser um dever como o é a lei moral, mas ela atende aos objetivos morais. A ideia de Deus é tomada apenas para gerar influência sobre a vontade humana (aumento de força) para que a lei moral encontre melhor guarida no ânimo, dado que no conceito de Deus podemos pensar de modo prático a realização do sumo bem. Enquanto uma "necessidade humana", de ter que pensar um fim último para suas ações morais, o objeto da razão prática (o sumo bem) cumpre um papel de suma importância na filosofia moral de Kant. Kant [1793] (2008), conforme a citação acima nos diz que a ideia de Deus (e com ela a possibilidade de realização do sumo bem) não é vazia "porque alivia a nossa natural necessidade de pensar um fim último", necessidade que se não fosse preenchida seria "um obstáculo para a decisão moral”. Kant [1793] (2008) ainda no diz em outra parte, referindo-se à necessidade do homem: “(...) mostra assim a necessidade, nele moralmente operada, de pensar ainda em relação com seus deveres um fim último como resultado seu. A moral conduz inevitavelmente à religião, pela qual se estende (...) à ideia de um legislador moral (...) (p.14)”. Como o único que pode realizar uma possível adequação entre liberdade e natureza e tornar possível o sumo bem no mundo só pode ser pensado na ideia de um Deus moral, Segundo Herrero (1991): "Por isso Kant pode caracterizar a Religião como o "conhecimento dos nossos deveres como mandamentos de Deus", não enquanto Deus é o fundamento do dever, mas enquanto efeito do dever realizado necessita da ação de Deus para sua realidade efetiva (p.74)". E conclui: "Por isso, o progresso moral, exigido 
pelo dever, apoia-se também na fé no ser supremo (...) (p.159)”. De acordo com esta posição o sumo bem é o que, em suma, ordena o imperativo categórico e para que o sumo bem seja possível é necessário o postulado da existência de Deus. O fim total (o sumo bem), ao contrário, segundo Kant [1793], faz referência à natureza humana, de ter que sempre, além da lei, um fim para agir. Por isso Kant [1793] (2008) nos diz:

(...) a proposição "faz do sumo bem possível no mundo o teu fim último" é uma proposição sintética a priori, que é introduzida pela própria lei moral e pela qual, no entanto, a razão prática se estende para lá desta última; tal é possível em virtude de a lei se referir à propriedade natural do homem de ter de pensar para todas as acções, além da lei, ainda um fim (propriedade do homem que faz dele um objecto da experiência) (...) (p.15).

O fim como objeto total da razão faz referência à necessidade humana que o faz objeto da experiência “de ter de pensar para todas as ações, além da lei, ainda um fim". O desdobramento do sumo bem mostrará no segundo capítulo um dever de índole especial, o dever da humanidade para consigo mesma. O fim que é posto como objeto da razão prática é por causa da "propriedade do homem que o faz objeto da experiência". Enquanto a lei moral é válida para todos os seres racionais, o objeto total da razão prática faz referência à necessidade humana. Por isso, o sumo bem não poderá ser completo sem a felicidade, mesmo que esta felicidade seja resultante da dignidade de ser feliz.

O fim total da razão prática é o objeto total conhecido como sumo bem. O conceito de sumo bem contém uma ambiguidade que deve ser levada em consideração antes de determiná-1o. Sumo bem pode significar o "bem supremo" ou "o bem consumado". O bem supremo é a moralidade (virtude como estado moral de entes racionais e finitos). Porém, enquanto é bem supremo, não é ao mesmo tempo o bem consumado. Segundo Kant (1788/2002), “o primeiro (..) é aquela condição que é ela mesma incondicionada, quer dizer, não está subordinada a nenhuma outra (originarium); o segundo é aquele todo que não é nenhuma parte de um todo ainda maior da mesma espécie (p.180)". A condição que é ela mesma incondicionada é a virtude; e o todo que não é parte de um todo maior é a moralidade acompanhada de felicidade. A virtude é a condição de tudo o que nos possa parecer desejável, inclusive a felicidade. Mas isso não significa que 
ela seja o bem consumado, pois para que a virtude seja o bem consumado é necessário que ela seja acompanhada de felicidade. A virtude é o merecimento à felicidade, mas ser merecedor da felicidade e não participar dela não pode coexistir com uma vontade reconciliada com a razão prática. Kant (1788/2002) nos diz:

(...) assim este sumo bem significa o todo, o bem consumado, no qual, contudo, a virtude é sempre como condição o bem supremo, porque ele não tem ulteriormente nenhuma condição acima de si, enquanto felicidade, sem dúvida, é sempre algo agradável ao que a possui, mas não algo que é por si só, absolutamente e sob todos os aspectos, bom, porém pressupõe sempre como condição a conduta legal moral (2002, p.181).

Para Kant a vinculação desses dois conceitos (virtude e felicidade) é uma conexão sintética e não analítica. Vincular dois conceitos distintos como se fossem a mesma coisa é no que incide o erro dos estoicos e epicuristas. Segundo Kant (2002), “O epicurista dizia: ser autoconsciente da máxima que conduz à felicidade, eis a virtude; e o estoico: ser autoconsciente de sua virtude, eis a felicidade (p.182)". Na analítica da CRPr (1788/2002), Kant mostrou que a lei moral é o único fundamento de determinação da vontade à ação. Já que esse fundamento é formal porque exige unicamente a forma da máxima universalmente legislativa, ficou provado, junto com isso, que a felicidade não pode ser computada entre os princípios de determinação de uma vontade moralmente determinada. O que é posto aqui é um problema para razão, já que os elementos do sumo bem não podem ser reunidos analiticamente ${ }^{24}$, mas é uma síntese de conceitos diferentes (virtude e felicidade) e a felicidade é necessária para que o sumo bem seja completo em seus elementos.

No sumo bem, a unidade entre virtude e felicidade é realizada e cada um dos elementos são hierarquicamente organizados. Sem um dos dois, a ideia do sumo bem se torna sem sentido. O vínculo entre os dois elementos do sumo bem são conectados. É necessário decidir a respeito do conceito prioritário na

24 Quando podemos vincular dois elementos analiticamente significa que se temos um conceito, temos ao mesmo tempo o outro por análise. Na síntese, ao contrário, dois conceitos diversos são reunidos. Na ideia do sumo bem virtude e felicidade são pensadas $a$ priori e estão vinculadas. Portanto, se for provada que tal vinculação é possível estaremos diante de uma síntese a priori. 
junção dos elementos do sumo bem. Kant parte das seguintes possibilidades: “(...) ou o apetite de felicidade ter que ser a causa motriz da virtude, ou a máxima da virtude tem que ser causa eficiente da felicidade (2002, p.185)". Parece que as duas opções são impossíveis.

A primeira possibilidade é improvável, dado que uma vontade determinada moralmente não pode agir com base no princípio da felicidade, mas apenas determinado pela lei moral; o segundo caso, também parece improvável porque não há nada na lei moral que garanta que, se agirmos por dever, teremos a felicidade como efeito necessário. Toda conexão prática de causas e efeitos no mundo não se segue de determinações morais, mas sim de acordo com leis naturais. Portanto, conclui Kant [1788] (2002): “(...) consequentemente, não pode ser esperada nenhuma conexão necessária e suficiente ao sumo bem, da felicidade com a virtude no mundo através da mais estrita observância das leis morais (2002, p.185)". Estamos diante de um problema, porque a ideia de sumo bem é um objeto aprioristicamente necessário da razão prática e “(...) interconecta-se inseparavelmente com a lei moral, a impossibilidade do primeiro caso tem que provar também a falsidade do segundo (2002, p.185)".

Até aqui, com respeito ao sumo bem, podemos dizer 1) O sumo bem é interconectado com a lei moral, por isso ele pode ser considerado um dever, já que na própria lei o objeto que lhe pertence está posto; 2) Que se ele não é possível de ser realizado a lei moral perde a sua validade ("falsidade do segundo"). Se o imperativo é um mandamento moral, então ele concede certo sentido que é representado na ideia de sumo bem. Se o sumo bem não é possível, então temos que afirmar que a lei moral também carece de sentido. Por isso Kant [1788] (2002) nos diz:

Portanto, se o sumo bem for impossível segundo regras práticas, então também a lei moral, que ordena a promoção do mesmo, tem que ser fantasiosa e fundar-se sobre fins fictícios vazios, por conseguinte tem que ser em si falsa (2002, p.185).

O sumo bem é o objeto supremo necessário de uma vontade determinada moralmente. Mas uma vontade moralmente determinada o é pela lei moral e não pelo apetite à felicidade. O que podemos sentir como efeito da lei moral é o sentimento de respeito e não o prazer na contemplação de um objeto 
apetecido. Nesse caso, como já foi mostrado, o respeito é efeito da lei moral e não o contrário. Segundo Kant [1788] (2002), "(...) é autocontentamento, que em seu sentido próprio sempre alude somente a uma complacência negativa em sua existência, na qual se é autoconsciência de não carecer de nada (p.191)". A consciência de não carecer de nada é a liberdade de agir determinado unicamente pela razão, sem necessidade de nada tirado da experiência, na medida em que sou autoconsciente dela, é a fonte de um autocontentamento ligado à lei moral. Portanto, um autocontentamento moral é efeito da consciência de nossa independência de impulsos da inclinação sensível. Pode-se, portanto, de acordo com a lei moral, ao determinar uma ação pelo ato (virtude), sentir ao mesmo tempo um autocontentamento consigo mesmo na sua independência da natureza. Mas esse autocontentamento não é a felicidade. O sumo bem, entretanto, só pode ser compreendido, se for compreendido junto com ele, a subordinação da felicidade como efeito da virtude. Segundo Júlio Esteves (1998), há dois significados para felicidade na filosofia moral de Kant:

Ora, deve-se notar que Kant distingue entre a busca da felicidade por ela mesma ou pelo amor de si (Selbstliebe), que é natural e desperta em nós antes da lei moral, e a busca da felicidade sob a condição da sua compatibilidade com a moralidade, que se chama então amor de si racional (vernünftigeSelbstliebe) (1998, p.152-153).

Colocando a felicidade como possível apenas em relação à virtude, portanto, com o segundo significado apresentado na citação acima, como amor de si racional, é que Kant vincula a felicidade com a virtude na ideia de sumo bem. A felicidade é proporcional à virtude. A virtude é a condição indispensável da felicidade.

Kant quer encontrar o modo pelo qual ele é possível. O problema é que tal vinculação só pode ser dada segundo leis da liberdade e não de acordo com as leis naturais. A vinculação do condicionado ao incondicionado só pode ter lugar nas coisas em si e não no fenômeno. Como a conexão sintética entre virtude e felicidade é dada a priori, ela não pode ser encontrada na experiência. Entretanto, a consequência prática dessa ideia é que as ações que objetivam tornar efetivo o sumo bem pertencem ao mundo sensível. Herrero (1991) enumera três impedimentos que se opõem à realização do sumo bem: 1) Ele coloca a própria moralidade como o primeiro impedimento à realização do 
sumo bem. É que para a moralidade produzir a felicidade como consequência ela deve ser pura e a virtude tem que ser totalmente livre. "Mas ao homem não é possível uma pureza completa de suas disposições morais (1991, p.46)"; 2) O mal radical (a propensão do homem à decisão de escolher máximas contrárias as leis morais) é o segundo impedimento à realização do sumo bem; 3) A natureza, já que as leis naturais não são idênticas às leis da liberdade da vontade. Como sair desse problema? Para resolver esse problema, temos que determinar de que modo é possível a união sintética a priori de virtude e felicidade. Para isso, Kant introduz os seus postulados ${ }^{25}$. Como é possível o sumo bem no mundo? Se o sumo bem tem que ser realizado no mundo, como reconciliar liberdade e natureza?

\subsubsection{Imortalidade da alma}

O sumo bem é objeto necessário de uma vontade determinada moralmente. Uma vontade determinada pela lei moral é uma disposição de ânimo totalmente conforme a lei moral. Logo, disposições conforme plenamente à lei moral tem que ser possíveis, já que estão contidas no mesmo mandamento moral que o homem deva ser perfeito moralmente. Porém, segundo Kant [1788] (2002), “(..) a plena conformidade da vontade à lei moral é santidade, uma perfeição da qual nenhum ente racional do mundo sensorial é capaz em nenhum momento de sua existência (2002, p.198)". Como a perfeição moral é um mandamento da razão, então ela deve ser buscada como objeto real de uma razão legisladora. O que podemos pressupor é que tem que ser possível um progresso à meta. Se ela ordena que sejamos perfeitos e não o podemos ser plenamente perfeitos, teremos que postular uma existência que seja perdurável ao infinito (a qual se chama imortalidade da alma). Segundo Kant (2002), “(...) esse progresso infinito somente é possível sob a pressuposição de uma existência e personalidade do mesmo ente racional perdurável ao infinito (a imortalidade da alma) (p.198)". A proposição que ordena o melhoramento moral até a perfeição moral é de suma utilidade para a filosofia moral de Kant. O problema é que se não for possível pensarmos (sem contradição) o postulado da imortalidade da alma, a lei moral correria o risco 
de tornar-se falsa ou indulgente. O que a lei ordenaria seria inalcançável e ela se tornaria "sonhos teosóficos" que contradizem a razão. Segundo esse postulado, temos que avançar até o fim para o qual estamos destinados pela razão. Segundo Kant [1788] (2002):

O que unicamente pode convir à criatura, em relação à esperança dessa participação, é a consciência de sua provada disposição para, a partir de seu atual progresso do pior para o moralmente melhor e do propósito imutável, tornado conhecido a ele por esse meio, esperar uma ulterior continuação ininterrupta desse progresso (...) (2002, p.199$200)$.

Com base no que foi dito acima, a imortalidade da alma é uma pressuposição necessária de uma vontade determinada pela lei moral. Como nós não somos perfeitos, tornou-se necessário afirmamos a imortalidade da alma. A imortalidade pressupõe 1) que o meu estado de imperfeição deve, devido representação da ideia de perfeição moral, almejar o aperfeiçoamento; 2) A disposição de melhorar moralmente é um dever moral; 3) Que o intento de melhorar tem que promover um "propósito imutável" de continuação para o melhor; 4) O postulado da imortalidade da alma resolve o problema entre ser e dever. O homem não é perfeito e, no entanto, a lei moral ordena que sejamos perfeitos. Existe aqui um problema moral porque a moralidade é uma adequação completa das disposições de ânimo à lei moral e os homens são imperfeitos. Como esse problema só pode ser resolvido através do postulado de uma continuação do moralmente imperfeito para o moralmente perfeito, o problema da moralidade (o primeiro elemento do sumo bem) é resolvido através do postulado da imortalidade da alma, que garante como possível, a pureza das intenções, ainda que só como meta infinita e não para fins teóricos.

Com o postulado da imortalidade da alma, tornamos possível o sumo bem na pessoa humana, o sumo bem supremo como virtude. Para o homem ter suas disposições adequadas ao reto dever moral, é necessário que suas potências sensíveis estejam estabelecidas desde a lei moral. Trata-se de um ideal de perfeição moral que gera um interesse pela realização desse fim e o torna possível por meio do postulado da imortalidade da alma. Segundo Kant [1788] (2002): 
complementação da incapacidade da razão especulativa mas também em relação à religião (2002, p.198).

A utilidade do funcionamento de um postulado prático diz respeitoà 1) “complementação da incapacidade da razão especulativa”; 2) "também em relação a religião". A primeira utilidade deve-se à novidade de um conceito, vazio para a razão especulativa, ganhar no âmbito prático importância de conceito necessário para realização do objeto total da razão prática, sem o qual a própria lei moral perderia o seu sentido verdadeiro. A segunda utilidade é em relação à religião. É que por meio dos postulados a religião terá o seu conceito determinado. Com a proposição de destinação moral, os conceitos transcendentes para a razão especulativa tornam-se imanentes para a razão prática e, assim, o conceito teológico de imortalidade da alma pode ser afirmado, sem que com isso, o queiramos conhecê-lo teoricamente. Tratase de uma necessidade prática e não de um objeto disponível para as nossas faculdades de conhecer. Os postulados querem responder à pergunta: o que posso esperar de meu reto agir moral?

Com a proposição de destinação moral que coloca como fim a perfeição de nossas disposições, ainda não conseguimos o bem consumado. O bem supremo como virtude fica garantido através do postulado da imortalidade da alma. Foi dito que, para realizar a felicidade como consequência da virtude, era necessária uma adequação das disposições morais como possível (virtude). Essa seria uma condição para ser merecedor da felicidade, mas ainda não é garantido que a felicidade será resultado de uma vontade moralmente determinada. O que foi garantido pelo postulado da imortalidade da alma é que é possível pensarmos um desenvolvimento moral a partir da ideia de perfeição como meta, e não que necessariamente que isso seja suficiente para que a felicidade seja resultado da virtude e tenhamos garantido a exeqüibilidade do objeto da razão prática.

É bom termos clara a distinção entre estado de santidade (que somente um ser absolutamente racional é capaz) e o de virtude. Júlio Esteves (1998) diz que a santidade não pode servir de meta para um ser sensível e racional. Na santidade, não há barreiras impostas pela sensibilidade. O que é buscado com o postulado da imortalidade da alma é a virtude (o máximo de força moral) e não a santidade (ausência de obstáculos no cumprimento moral). Ele nos diz 
(1998):

Ora, virtude e santidade podem ser ambas definidas como "adequação completa à lei moral", e isso talvez explique a imprecisão cometida por Kant no emprego dos termos. Contudo, enquanto a santidade é a adequação completa à lei moral por parte de uma vontade em que estão ausentes princípios de determinação sensíveis e muitas vezes contrários àquela, a virtude é uma adequação completa à lei em oposição constante às inclinações e à possibilidade de cair na tentação de inverter a ordem de subordinação original das últimas relativamente à lei moral $(1998$, p.153).

Portanto, é garantido no postulado da imortalidade da alma a virtude como uma adequação completa à lei moral "em oposição constante às inclinações e à possibilidade de cair na tentação", fazendo uma distinção clara em relação à santidade como "adequação completa à lei moral", mas sem que exista um oponente que se interponha ao melhoramento moral. Na santidade, a vontade é totalmente adequada à lei moral, sem a possibilidade de algum poder se desviar da lei moral. A virtude é um empreendimento de força para cumprir o dever moral. Os homens, enquanto seres de sensibilidade e razão tem outros impulsos distintos ao que é promovido pela lei moral. Desse modo, o arbítrio humano fica na bifurcação entre os impulsos das faculdades sensíveis e o respeito pela lei moral. O respeito é o motivo subjetivo gerado pela lei moral, em oposição aos sentimentos de prazer e desprazer na representação de algum objeto da experiência. Portanto, o homem não é e nunca poderá ser santo. Por isso, Kant tem o cuidado de conceder à virtude o lugar de primazia no dever de promover o sumo bem. Ela garante (pelo menos como possível) a virtude mais plena. A imortalidade é, portanto, necessária para que o primeiro elemento do sumo bem seja possível. Mas e a felicidade? Como a partir da virtude é possível chegar a ela?

Passaremos para o próximo postulado. Através dele, Kant [1788] (2002) tenta tornar possível a reunião entre virtude e felicidade, incidindo também na junção entre liberdade e natureza, já que a moralidade pertence à liberdade, e a felicidade é um sentimento sensível regido por leis naturais da necessidade. Através do próximo postulado poderemos resolver esse problema e chegar ao conceito racional de religião. 


\subsubsection{O postulado de Deus}

O segundo postulado visa resolver o problema posto pelo conceito de sumo bem, que exige uma concordância da liberdade com a natureza, já que a moralidade deve produzir a felicidade como seu efeito. O primeiro elemento do sumo bem foi tornado possível e o segundo terá que ser também possível, para que o conceito de sumo bem ganhe uma possibilidade prática com motivo para o agir moral. Segundo Kant [1788] (2002), "Felicidade é o estado de um ente racional no mundo para o qual tudo se passa segundo seu desejo e vontade e depende, pois da concordância da natureza com todo o seu fim (2002, p.201)". O homem enquanto é determinado pela lei moral, é de acordo com sua natureza racional, livre dos impulsos sensíveis. Por isso, a felicidade não pode ser causa da moralidade. O imperativo categórico ordena sem que seja levada em conta a felicidade. As ações morais acontecem no mundo, mas a determinação da vontade pela lei moral é independente do mundo natural. O nosso desejo pela felicidade é uma carência de nossa constituição finita e sensível e não absoluta como a lei moral. Para ser realizado, o sumo bem tem que poder tornar possível a virtude e a felicidade como consequência. Júlio Esteves (1998) faz a seguinte afirmação:

O sumo bem é o conceito que reúne sob si os fins propostos pela lei moral e aqueles propostos pela natureza sensível, mas compatíveis com a moralidade, ordenados e unificados pela razão em sua atividade peculiar de sistematização. Em suma, a máxima perfeição moral (virtude) aliada ao máximo de satisfação das inclinações compatíveis com a lei moral (felicidade), i.e. o sumo bem, é o fim último da vontade do ser racional finito, na medida em que tem uma disposição (Gesinnung) moralmente boa e exerce aquela atividade peculiar à razão, tanto no seu uso prático quanto no teórico, que consiste em formar a ideia de uma totalidade incondicionada(p.23).

$\mathrm{Na}$ CRP [1781] a dialética é uma investigação das ilusões da razão especulativa. Foi mostrado, por exemplo, que a razão especulativa procurou o incondicionado(liberdade) e foi incapaz de afirmar objetivamente o seu conhecimento. O incondicionado (sumo bem como objeto total da razão prática) para a razão prática é o sumo bem como objeto total da razão (fim 
terminal). O sumo bem é a união entre moralidade e felicidade como fim $a$ priori imposto pela razão através da lei moral. Segundo Kant [1788](2002):

\begin{abstract}
Como razão prática ela procura para o praticamente condicionado (que depende de inclinações e de uma carência natural) igualmente o incondicionado e, em verdade, não como fundamento determinante da vontade; mas, ainda que este tenha sido dado(na lei moral), ela procura a totalidade incondicionada do objeto da razão prática pura sob o nome de sumo bem(p.176).
\end{abstract}

O problema é que a natureza (onde a felicidade deve ser realizada como consequência da virtude) não é regida por leis da liberdade e sim por leis da necessidade. Não há na lei moral nada em si mesma que, analiticamente, pudéssemos conceber a felicidade como consequência da virtude. O que vemos no mundo é os honestos se tornarem infelizes por serem morais. Virtude não garante que a felicidade seja sua consequência. E o contrário também é verdadeiro: a desonestidade não priva o homem da felicidade. $O$ honesto pode ser feliz ou não, assim como o desonesto, mas que só de forma relativa. O que é garantido racionalmente é que o honesto merece ser feliz. O virtuoso merece ser feliz. Merecer ser feliz e não sê-lo contradiz a razão. Para que a felicidade pudesse se tornar resultado da virtude, a natureza precisaria ser posta como fim moral, assim como o homem em sua personalidade moral. O fim supremo da natureza teria que ser o fim supremo da moral. A felicidade moral (consequência da moralidade) depende da concordância da natureza com o imperativo categórico. Mas o dever de promover o sumo bem no mundo é o objeto necessário da lei moral e deve ser possível. O homem, enquanto pertencente à natureza, não pode ser causa dela. Não há nele forças para fazer com que a natureza se reconcilie com sua liberdade. Segundo Júlio Esteves (1998),

Pois, de um lado, a lei da razão pura prática põe o sumo bem como objeto necessário da vontade do ser racional finito, por conseguinte, como algo possível por essa sua vontade. Porém, de outro lado, a reflexão prática sobre as condições às quais está submetido o ser racional finito em suas ações morais evidencia que o sumo bem não é possível por sua vontade (1998, p.157).

O mundo inteligível (mundo moral) tem suas próprias leis. A natureza sensível tem também suas próprias leis de funcionamento. Entretanto, o dever de promover o sumo bem no mundo leva-nos a afirmar a interconexão entre 
liberdade e natureza. Nós, enquanto seres também de natureza, não podemos realizar a reunião entre natureza e liberdade. É uma carência de nossa constituição que não possamos controlar o mundo natural. O que os homens realizam pela liberdade, acontece no mundo natural. As ações se dão no mundo natural, ainda que a sua origem seja uma decisão anterior ao acontecimento. O que os homens não podem é prever os resultados de suas ações. Tem que haver alguma possibilidade de algum fundamento distinto da natureza, mas que é o seu fundamento. Não somente fundamento da natureza, mas da interconexão entre natureza e liberdade. Mesmo que a vontade do homem seja livre, ele não é capaz de mudar o curso dos eventos. Segundo Kant [1788] (2002):

Portanto, é postulada também a existência de uma causa da natureza distinta da natureza em conjunto, e que contenha o fundamento dessa interconexão, a saber, da exata concordância da felicidade com a moralidade (2002, p.201-202).

É necessário um postulado que garanta a interconexão entre felicidade e moralidade, promovendo assim a reconciliação entre a nossa constituição natural e a nossa constituição inteligível. Em outras palavras, o postulado em questão deve ter uma natureza distinta da natureza "em conjunto" e ser o fundamento da interconexão exata entre moralidade e felicidade. Como causa da natureza, ele é capaz de reuni-la com a liberdade para que o objeto da razão prática pura possa ser realizado em conjunto com as leis morais. Assim como os elementos do sumo bem têm uma hierarquia bem definida (a virtude é o bem supremo e a felicidade deve ser a sua consequência), na relação entre liberdade e natureza, é a liberdade que tem a primazia. Não é a liberdade que tem que se submeter às leis naturais, mas a natureza e suas leis devem seguir o curso da liberdade. A liberdade é a pressuposição mais fundamental de uma ação moral, mas a pressuposição de Deus, como reconciliador de natureza e liberdade, faz com que o objeto da razão prática seja possível de ser realizado, a saber, a unidade entre virtude e felicidade.

O fato de que o homem por sua própria vontade não pode realizar o sumo bem no mundo, leva-nos a uma incoerência interna do dever moral. A lei moral ordena algo que o homem não pode realizar. Isso significa que o sumo bem corre o risco de ser abandonado e, com ele, todo o poder da lei moral, já que a lei moral ordena um fim que parece impossível. Mas a lei moral já foi 
supostamente provada por um factum da razão. Com ela, a liberdade também ganha objetividade prática. A liberdade só é plenamente realizada se puder encontrar concordância com a natureza. A necessidade do sumo bem no mundo leva a consciência moral aos postulados. Para isso, a razão encontra nas ideias transcendentes para a razão especulativa uma utilidade prática objetiva para a razão prática. Desse modo, “(...) o sumo bem só é possível no mundo na medida em que for admitida uma causa suprema da natureza que contenha uma causalidade adequada à disposição moral" (1788/2002, p.202). O postulado, nesse caso, é "uma causa suprema da natureza" e contém uma causalidade "adequada à disposição moral". Um ente que preenche a carência subjetiva do homem só pode ser pensado como inteligência e vontade, como causa da natureza. Segundo Kant (1788/2002):“A causa suprema da natureza, na medida em que tem que ser pressuposta para o sumo bem, é um ente que mediante entendimento e vontade é a causa (consequentemente o autor) da natureza, isto é, Deus (2002, p.202)".

É necessário entendermos que o postulado da existência de Deus não é um dever. Mas como o sumo bem é um dever, então podemos admiti-lo como existente apenas para fazer com que o sumo bem derivado (o melhor mundo adequado às intenções morais), possa ser garantido como possível. O postulado da existência de Deus é uma necessidade que se vincula à carência do agente moral de "pressupor" a existência de Deus como necessária para realização do sumo bem. Por isso Kant nos diz (1788/2002): “Consequentemente o postulado da possibilidade do sumo bem derivado (do melhor mundo) é ao mesmo tempo o postulado da efetividade de um sumo bem originário, ou seja, da existência de Deus (p.203) (grifo do autor)”. Não é uma necessidade teórica que nos leva a Deus, mas sim uma necessidade prática de pressupô-lo para a realização do sumo bem no mundo.

A ideia de razão prática descobre em nós o suprassensível como liberdade. Por isso, os fenômenos da liberdade remetem à própria liberdade como fundamento ou causa. Segundo Herrero (1991):

Mas essa causa, a liberdade, não é suficiente para produzir o fim término que, como fenômeno, deve existir no mundo. Para que esse fim possa realizar-se, fomos obrigados a atribuí-la também a uma causa suprassensível, criadora do mundo (1991, p.68). 
A nossa liberdade não é causa suficiente para produzir o sumo bem no mundo. O sumo bem deve ser realizado no mundo. Por isso, atribuímos a uma causa criadora da natureza e legisladora da liberdade como unidade de reunião entre natureza e liberdade. Por isso, a religião que emerge daí só poderia atender aos interesses práticos morais e não teóricos. A religião é resultado da pressuposição moral da existência de Deus. Kant [1788] (2002) nos diz:

\begin{abstract}
Dessa maneira a lei moral conduz, mediante o conceito de sumo bem enquanto objeto e fim terminal da razão prática pura, à religião, quer dizer, ao conhecimentos de todos os nossos deveres como mandamentos divinos, não enquanto sanções, isto é, decretos arbitrários, por si contingentes de uma vontade estranha e, sim, enquanto leis essenciais de cada vontade livre por si mesma mas que apesar disso têm que ser consideradas mandamentos do Ser supremo, porque somente de uma vontade moralmente perfeita (santa e benévola), ao mesmo tempo onipotente, podemos esperar alcançar o sumo bem que a lei moral torna dever (...) (2002, p.208) (grifo meu).
\end{abstract}

A religião é a lei moral compreendida como mandamento divino. Como já foi dito, ela se diferencia da moral somente quanto a forma, já que no conceito de religião temos a idéia de Deus para engendrar o cumprimento da lei moral pelo homem. Somente um ser capaz de interconectar liberdade e natureza tem poder para realizar o sumo bem no mundo. Esse ser supremo não pode ser externo à razão prática. Ele promana dela e para realizar o seu objeto no mundo é que o Ser supremo serve à disposição moral. Desse resultado, podemos concluir: 1) O conceito de religião atende a necessidade de tornar possível o sumo bem; 2) Os decretos divinos não podem ser arbitrários. Arbitrários aqui devem ser compreendidos os que estão em oposição ao mandamento moral; 3) A lei moral tem o seu fundamento na autonomia do sujeito, mas o seu objeto só poderá ser realizado se pressupormos a existência de Deus; 4) Nada na religião estatutária que esteja em oposição à lei moral pode ser compreendido como mandamento divino. O conceito de religião é único e promana da lei moral. A religião enquanto conceito é necessária para a realização da liberdade. Tudo o que na religião se opuser ao moral fica descartado como pertencendo a um falso conceito de religião. É com esse conceito que promana da moral, que é necessário para realização do sumo bem, que poderemos empreender uma crítica a toda religião estatutária. O conceito é racional e atende aos fins práticos e não teóricos da religião. 
Através desse conceito, é empreendida por Kant uma interpretação nova do lugar que a religião deve ocupar na vida humana. Os dogmas históricos terão um valor distinto do que é dado pela religião estatutária. A religião pura deverá ser levada em consideração todas as vezes que uma doutrina é investigada. Por meio da relação que é aqui estabelecida, Kant retomará doutrinas centrais da religião cristã e fará com que conceitos provindos da religião estatutária sejam reinterpretados à luz do conceito de moral.

Estamos diante de um conceito natural de religião. A religião é assumida aqui como parte que resulta de exigências morais. Todos os homens podem comunicar o conteúdo da religião racional porque não se trata de uma religião positiva (limitada ao tempo e espaço de sua constituição), mas de uma religião da razão, onde se exige apenas a tomada da lei moral como máxima fundamental para todas as ações. É uma religião do coração e não de culto. E religião racional e não revelada. Não precisamos de um livro sagrado ou uma revelação para sermos membros dessa religião. Aqueles que são dessa religião optaram por uma vida moral e esperam a felicidade como dádiva de Deus. O resultado será o enunciado por Kant [1793]: "O conceito de uma vontade divina determinada segundo meras leis morais puras permite-nos pensar, assim como um só Deus, também apenas uma religião que é puramente moral (p.110)". Como Kant entende as religiões positivas? Ele [1793] diz: "Há somente uma (verdadeira) religião, mas pode haver múltiplos tipos de fé (p.113)". Como relacionar esse múltiplos tipos de fé, com a ideia de que há apenas uma religião verdadeira?

No próximo capítulo abordaremos a relação entre o conceito de religião pura e o de religião estatutária. Na investigação empreendida no livro $A$ religião nos limites da simples razão (1793), Kant aplicará o conceito de religião pura à religião histórica, onde a religião assumirá uma função prática e dispensará tudo o que não está de acordo com a moral. 


\section{Capítulo 2 - A religião racional e a religião estatutária ou positiva}

O texto de Kant intitulado A religião nos limites da simples razão [1793] (2008) é resultado de sua preocupação com o fenômeno religioso na sua relação com a ética. O seu intento nesse livro é aplicar o conceito puro de religião ao fenômeno concreto da religião estatutária. Os conteúdos da fé histórica são interpretados desde a fé moral, ou seja, desde uma fé que resulta de exigências puramente morais. Com a distinção entre o conceito verdadeiro de religião e sua diferença em relação à religião estatutária, Kant empreenderá uma revisão dos conteúdos da religião, especialmente os do cristianismo. Apesar de sua abordagem mais centrada no cristianismo, o que importa, para Kant, é o modo como os símbolos cristãos podem ser interpretados a partir das exigências da razão prática pura. No embate entre a religião moral e a religião estatutária, ele muda dogmas religiosos considerados pilares para a fé cristã. Nesse embate é estabelecido que uma religião positiva, que não incorpora às suas proposições de fé o elemento moral como prioridade, na sua relação com os conteúdos revelados, perde o sentido de sua existência. Não somente isso, mesmo a religião que assume a melhora moral dos fiéis como meta de sua realização final, deve ceder lugar à religião pura da razão, a fim de que os símbolos representativos da religião revelada cedam lugar à ideia de uma religião da boa conduta. As religiões históricas devem, desse modo, tomar a moral e não práticas externas (cultos, orações, entre outras), como fundamento de todo o seu fazer. Essa forma de religião é falsa se não coloca a ideia de uma religião da razão como fundamento de toda a interpretação de seus conteúdos revelados. Segundo Kant [1793] (2008): “Quando se tem de fundar uma religião moral (que não deve estabelecer-se em estatutos e observâncias, mas na intenção do coração de cumprir todos os deveres humanos como mandamentos divinos) (...) (2008, p.90)". Como os homens historicamente ainda não se conformaram ao dever de se reunir em uma religião que brota de um coração transformado para cumprir o dever moral, erigiram uma religião estatutária (baseada na revelação) e inverteram a ordem hierárquica entre religião racional e religião estatutária, ao colocarem no lugar da verdadeira religião a religião baseada na revelação. 
A religião nos limites da simples razão é uma religião que resulta da aplicação do conceito puramente racional ao fenômeno da religião estatutária a fim de que a religião estatutária possa ser substituída pela religião moral.Mostra apena que não há uma incompatibilidade entre as duas. Mesmo a religião, que resulta da submissão da religião positiva (revelada ou estatutária) à religião racional (moral), é considerada apenas como meio para a religião racional, que dispensa toda forma de representação e se conforma apenas com a ideia racional de religião. Nesse sentido, o conceito de religião racional puro, aplicado à religião estatutária, que resulta numa religião nos limites da simples razão, não poderá ser exclusivamente da razão, mas também contém conteúdos históricos. Segundo Kant [1797] (2008):

Podemos, efetivamente, falar de uma "religião nos limites da simples razão", a qual não é, entretanto, derivada exclusivamente da razão, mas é também baseada nos ensinamentos da história e da revelação, e considera apenas a harmonia da pura razão prática com estas (mostra que inexiste um conflito entre elas). Mas nesse caso, igualmente a religião não é pura; é, ao contrário, religião aplicada a uma história que é entregue a nós, e não há lugar para ela numa ética que é pura filosofia prática (p.330) (grifo meu).

A tarefa de Kant no livro A religião... [1793] (2008) é aplicar o conceito de religião à religião revelada ou histórica. A religião que emerge dessa aplicação do conceito de religião à religião revelada não é totalmente pura (independente da experiência), mas é "também baseada na história e na revelação", considerando apenas a harmonia entre religião pura e religião estatutária. O conceito puro de religião, como já foi visto, emerge da lei moral, por isso, podemos dizer, que um tal conceito tem lugar em uma "ética que é pura filosofia prática". Ao contrário, umas das tarefas do livro $A$ religião (1793) é mostrar como é possível um acordo entre religião pura e religião histórica. O acordo, na verdade, significa a submissão da religião revelada ou estatutária ao conceito puro de religião. Trata-se de pensar como é possível a relação entre moral (religião pura) e história na sua contingência (religião estatutária).

O livro A religião (1793) se insere na tentativa de Kant de superar os entraves da realização do sumo bem na história. Mas como as aporias da história impossibilitam a experiência concreta da realização da liberdade, já que experimentamos no mundo o fenômeno da imperfeição face à perfeição 
moral posta pela ideia de sumo bem, segundo Herrero (1991):

Kant não poderá considerar propriamente a história como a realização do soberano bem comunitário (apesar dessa tendência nunca ser totalmente abandonada), mas considerará a história tal como ela se apresenta em sua faticidade, e tratará de interpretá-la em seu conteúdo a partir da razão prática. A história será submetida a um processo de desmitologização em favor do que a razão prescreve como universal, e o restante será entendido como "veículo", destinado um dia a desaparecer, para introduzir paulatinamente a verdadeira e única religião da razão (p.150) (grifo meu).

A história é contingente e os ensinamentos religiosos que estão inseridos na tradição carecem de valor absoluto. É na história que o sumo bem deve ser realizado, mas não podemos colher da experiência essa reunião exigida para sua concretização. Por isso, as doutrinas da religião estatutária ou revelada (históricas) estão em desacordo com os princípios morais. Isso não significa que Kant queira dispensar a religião revelada, mas que a religião estatutária, por meio da ideia de religião, em primeiro lugar, sofra um processo de desmitologização de seus símbolos contrários aos deveres morais e o estabelecimento de um sentido moral das representações religiosas; e em segundo lugar, que os próprios símbolos desapareçam, porque é destinado a um dia desaparecer, para introduzir paulatinamente a verdadeira e única religião da razão. Desse modo, a religião enquanto "veículo" da moral deverá desaparecer, cedendo lugar à religião pura da razão. Não ser apenas uma "religião nos limites da simples razão", e sim a verdadeira religião da razão que brota da moral e nela permanece, podendo, desse modo, fazer parte de uma ética que é também pura filosofia prática (que promana unicamente da razão) e dispensar os elementos da revelação e da história.

No estudo do sumo bem, tal como foi exposto no capítulo primeiro desse trabalho, nos foi mostrado que o postulado de Deus surge para atender uma carência subjetiva, necessariamente prática, provinda da necessidade do objeto total da razão prática. É dever promover o sumo bem, mas os homens não podem reunir mundo natural e liberdade. Foi também mostrado que a virtude (como primeiro elemento do sumo bem), e o que almeja (a adequação das disposições morais ao comando moral) precisava ser possível e que o postulado da imortalidade da alma apontava para um desenvolvimento de todas as nossas faculdades morais como possível. O merecimento à felicidade, em função do empenho sincero no cumprimento do dever (virtude), não 
garantiu a possibilidade da felicidade como consequência, por isso, um abismo se abriu entre as leis morais e as leis naturais. O homem não pode reconciliar as leis morais com as leis naturais. Ainda que o homem se empenhe o máximo que puder para reconciliar natureza e liberdade, não está sob sua posse o poder para fazê-lo. Apenas Deus, um ser supremo, é capaz de realizar a reconciliação do mundo com as leis da liberdade. Por isso, o postulado da existência de Deus possibilitava, sem contradição, que um conceito vazio para a razão teórica, pudesse preencher uma necessidade prática. Com o postulado de Deus, chegamos ao conceito puro de religião, compreendida como "todos os nossos deveres como mandamento divino". Tomarmos as leis morais como mandamentos divinos não significa, entretanto, que o fundamento da moral esteja na existência de Deus. Ao contrário, o postulado de Deus emerge como consequência do imperativo categórico. A lei moral tem o seu fundamento na forma universal da máxima, e o sumo bem é o seu objeto necessário por consequência e não como fundamento. Seria irracional merecermos a felicidade pela virtude e não podermos ter alguma esperança da felicidade. O postulado de Deus garante (pelo menos como possível no pensamento) que a felicidade seja proporcional à virtude. $\mathrm{Na}$ medida em que somos virtuosos, podemos esperar a felicidade como resultante da atuação de Deus, para garantir a felicidade, como consequência da virtude. Segundo Kant [1788] (2002): “(...) essa doutrina moral pode chamar-se também doutrina da felicidade, porque a esperança dela só começa com a religião (p.210)". Deus é, portanto, segundo Kant, a fonte de toda a nossa esperança do sumo bem no mundo (virtude e felicidade numa unidade sintética) e não um objeto disponível para o conhecermos teoricamente.

Com postulado de Deus podemos ainda dizer: 1) Somente ele tem o padrão de medida para medir a diferença entre virtuosos e não virtuosos, impedindo assim que o mundo seja injusto, mas que a justiça consista na retribuição (felicidade) aos que são determinados nas suas máximas ao cumprimento do dever moral; 2) Que o conceito de Deus tem um objeto prático (sumo bem) e, por isso, não é vazio para o saber prático, mas é vazio para o saber teórico, já que não podemos achar um objeto correspondente que seja dado na experiência para o campo do conhecimento, por isso Kant diz: "Esses postulados não são dogmas teóricos, mas pressuposições em sentido necessariamente prático (...) [1788] (2002, p.212)”. Esse segundo item serve 
para caracterizar o postulado da imortalidade da alma também. O resultado, portanto, já que Deus não é uma necessidade objetiva e sim prática, é que Deus é apenas uma ideia da razão necessária para a efetivação do sumo bem no mundo. Não podemos conhecer teoricamente o postulado de Deus. Deus é uma necessidade prática que nasce de uma carência prática. Deus é o meio pelo qual Kant tornou possível a reconciliação entre natureza e liberdade. A religião é, portanto, de procedência moral. Ela é a consumação da liberdade no mundo, já que a unidade de liberdade e natureza é pressuposta na ideia de sumo bem que é garantida por Deus. Por isso, como já foi dito no primeiro capítulo, Kant faz a seguinte afirmação sobre o conceito de religião e sua relação com a moral [1798] (2008):

A religião não se distingue em ponto algum da moral quanto à matéria, quanto ao objecto, pois tem em geral a ver com deveres, mas distingue-se dela só formalmente, ou seja, é uma legislação da razão para proporcionar à moral, graças à ideia de Deus engendrada a partir desta, uma influência sobre a vontade humana para o cumprimento de todos os seus deveres (2008, p.51).

Portanto, a religião e a moral são o mesmo, já que em ambas o homem se relaciona com deveres morais. A distinção é formal devido ao acréscimo da ideia de Deus à lei moral na religião, que serve para influenciar a vontade humana para o cumprimento do dever. Desse resultado, podemos fazer as seguintes afirmações: 1) a religião é um conceito que procede da moral;2) Deus é compreendido como uma ideia necessária para a possibilidade de efetivação do sumo bem; 3) A religião não se distingue da moral quanto ao seu objeto; 4) O conceito de Deus não procede de uma revelação, mas de uma necessidade prática.

Os deveres morais são tomados como mandamento divino na religião da razão. Entretanto, o fundamento da moral está na liberdade da vontade (autonomia). Parece que o conceito de Deus despurifica a lei moral como único móbil de determinação da vontade. Nesse caso, teríamos uma heteronomia da vontade. No entanto, não é admitido um fundamento moral baseado numa heteronomia da vontade. Deus e sua inserção no conceito puro de religião não poderia manchar a pureza da lei moral. Por isso, deveres para 
com Deus significam deveres para os homens. O Kant tardio [1797 ${ }^{26}$ ] (2008) diz: "Este dever relativamente a Deus (...) é um dever de um ser humano para consigo mesmo, isto é, não é objetivo, uma obrigação de prestar certos serviços para outro, mas apenas subjetivo, a favor do fortalecimento do incentivo moral na nossa própria razão legisladora (p.329-330)”.

Como a ideia de Deus surge da necessidade de efetivação do sumo bem no mundo, então ela surge para suprir uma carência subjetiva do homem não poder, por força própria, realizar o sumo bem. Deus é resultado da representação do objeto terminal da razão pura prática. Desse modo, a ideia de Deus é um meio de incentivar o agir moral e não pode ser tomada objetivamente, como se Deus pudesse ser conhecido teoricamente, fora de nossa ideia.

O modo possível de agradar a Deus é agindo moralmente. O sentido de postular é infundir influência sobre a vontade humana, para que a lei moral possa determiná-la suficientemente. Por isso, os deveres para com Deus (no sentido que é tomado no conceito puro de religião) são deveres do homem para consigo mesmo. Obedecer a Deus é cumprir o dever moral. E cumprir o dever moral significa obedecer a nossa própria razão. Eis o que podemos concluir do conceito racional de religião.

Para podermos vislumbrar a relação que é estabelecida entre religião racional e religião estatutária, é necessário compreendermos como é que o homem erige religiões baseadas na revelação quando a verdadeira religião é resultado do suprassensível em nós (a lei moral). Para adentrarmos na religião, é pressuposto que nossas disposições morais já tenham sido transformadas para promover o sumo bem no mundo. Entretanto, A religião..[1793] apresenta mais um impedimento para a realização do sumo bem, a saber, a propensão do ser humano de tomar máximas opostas à lei moral e inverter a ordem do dever. Como é possível que um ser que é propenso ao mal possa fazer o bem e promover, com todas as forças possíveis, o estabelecimento do sumo bem no mundo? Essa pergunta precisa ser respondida para mostrarmos como Kant relaciona religião pura e religião revelada.

26 Refiro-me aqui ao texto: "Metafísica dos costumes", que foi escrito em 1797, quatro anos depois do texto "A religião nos limites da simples razão", que foi escrito em 1793. 


\subsection{Propensão para o mal}

O problema fundamental de "A religião nos limites da simples razão (1793)" é, segundo Kant (1793): “(...) tornar manifesta a relação da religião com a natureza humana, sujeita em parte a disposições boas e em parte a disposições más (...) (p.18)". Se, para sermos verdadeiramente religiosos, devemos tomar a lei moral como máxima de nossa ação, e a lei moral é racional, então a religião tem relação íntima com a natureza humana, já que obedecermos a Deus significa obedecermos ao comando de nossa própria razão, ou seja, os deveres para com Deus são deveres do homem (razão) para consigo mesmo. Por isso, é preciso tornar manifesta a relação da religião com a natureza humana" e olhar de perto como o homem se relaciona com o conceito de religião. Segundo Zingano (1988) não bastam as condições de uma vontade em geral para pensarmos a relação entre dever moral e cumprimento moral pelo homem. Na CRPr (1788) o homem é, na maior parte das vezes, visto em sua generalidade. Apenas no A Religião[1793] Kant mostra a sua tese de uma propensão para o mal na natureza humana, em parte boa e em parte mau.

Em primeiro lugar, não existe na filosofia moral de Kant uma incompatibilidade entre liberdade e propensão para o mal. Kant conserva a sua ideia de que o homem pode por si mesmo determinar-se pela lei moral. Na CRPr [1788] (2002) preocupou-se em mostrar a lei moral como factum da razão e que a vontade é subjetivamente determinada pela lei moral objetiva. O que não foi levado em consideração, nessa crítica, é que a liberdade é capaz de insurgir-se contra si mesma, e tomar como móbil do agir, fundamentos diferentes dos provindos da lei moral. O problema deixado de lado na $C R P r$ [1788] (2002) é que a maldade é um ato livre da vontade. E mais, que o ato (que toma a inversão da lei como máxima do agir) é uma propensão natural da natureza humana, que pertence a todo gênero humano. Mas com a expressão “natureza humana” não se deve confundir a questão. Segundo Kant [1793] (2008):

Mas para que não se tropece logo no termo natureza, o qual, se (como habitualmente) houvesse de significar o contrário do fundamento das acções por liberdade, estaria em contradição directa com os predicados de moralmente bom e moralmente mau, importa observar que, por natureza do homem, se entenderá aqui apenas o fundamento subjectivo do uso da sua liberdade em geral (sob leis morais objectivas), que precede todo o facto que se apresenta aos sentidos, onde quer que tal 
fundamento resida (p.27).

Natureza na Religião nos limites da simples razão [1793] é o fundamento subjetivo de todo o uso de nossa liberdade em geral (sob leis morais) e não uma esfera que é regida por leis naturais de necessidade. O que torna uma ação reprovável moralmente é a máxima que toma para si inclinações subjetivas como fundamento do agir. Uma decisão que toma uma máxima fundamental de seguir a lei moral (ou não) não é um ato natural. Por isso, é uma decisão inteligível que decide contra a lei moral, assim como a que toma como máxima do agir a própria lei moral. Segundo Kant [1793] (2008): “(...) por conseguinte, o juízo de que o autor seja um homem mau não pode com segurança basear-se na experiência (p.26)".

Se fosse possível inferir a maldade da experiência, seria necessário afirmar que são os impulsos naturais que fundam a ação má, então teríamos uma contradição com a ideia de liberdade, porque teríamos que afirmar o contrário dela, ou seja, que o homem é sempre determinado por uma causa que o produz como efeito. Para agir, o homem precisa tomar uma máxima como fundamento do agir. A tomada de uma máxima pressupõe a liberdade da vontade, já que, para se tomar uma máxima, tem que ser possível escolher um princípio em detrimento de outro. O contrário disso seria o abandono do conceito de liberdade. Mas, para a moral, a liberdade é pressuposta como necessária aos predicados de "moralmente bom" ou "moralmente mau". Somente o homem pode escolher o que fazer na hora de agir. Se isso não fosse assim, estaria em contradição direta com os predicados de moralmente bom e moralmente mau. Como poderíamos imputar uma ação ao homem se não fosse pressuposto que ele pudesse decidir na hora de agir? Mesmo com a propensão do homem para o mal (afirmada por Kant) é garantido que o homem ainda é livre para deixar o mal que, por uma decisão livre, o tirou do bom caminho.

O homem é que põe, pela liberdade, a qualidade de uma ação e de si mesmo. Por isso, Kant [1793] (2008) diz que o fundamento de adoção das máximas, como não pode ser dado na experiência, mas é encontrado antes de toda ela (inteligível), é inato. Inato somente na medida em que é posto na base de todo o uso da liberdade, "(...) por isso, é representado como presente no homem à uma com o nascimento; não que o nascimento seja precisamente a causa dele [1793] (2008) (p.28)". Quando dizemos “o homem é mau por natureza”, 
queremos dizer que o fundamento de adoção das máximas moralmente más está contida no homem de modo universal (na espécie humana). A expressão "á uma com a nascimento" quer dizer que antes de todo e qualquer ato fenomênico é pressuposto uma ato de liberdade, que nesse caso optou pelo princípio do mau. Segundo Loparic (2007): “(..) essa propensão, chamada 'mal radical', expressa o caráter da espécie e, por isso, pode ser pressuposta como subjetivamente necessária em todo indivíduo humano (p.88)".

Segundo Kant [1793] (2008): "(...) a liberdade do arbítrio tem a qualidade inteiramente peculiar de ele não poder ser determinado a uma ação por móbil algum a não ser apenas enquanto admitiu na sua máxima (o transformou para si em regra universal de acordo com a qual se quer comportar) (...) (p.31)”. Só assim é possível um móbil para o homem. De outro modo a ação não poderia ser imputável. O homem tem sempre a possibilidade fazer diferente do que fez, ou ter feito diferente depois que já fez. Segundo Kant [1793] (2008): "A disposição de ânimo, o primeiro fundamento subjectivo da adoção das máximas, só pode ser única, e refere-se universalmente ao uso integral da liberdade. Mas ela própria deve ter sido adotada também pelo livre arbítrio, pois de outro modo não poderia ser imputada (p.31)”. A disposição de ânimo (Gesinnung ${ }^{27}$ ) é o primeiro fundamento ao uso integral da liberdade, isto é, a disposição de ânimo é o pressuposto necessário do uso da liberdade em geral. Ainda sobre o "uso integral da liberdade", podemos afirmar que, com essa expressão, Kant queira chamar a atenção para o fato de que "todo exercício da liberdade, mesmo o primeiro, requer um fundamento subjetivo em uma disposição para o bem ou mal". Em todo uso que fazemos de nossa liberdade é pressuposta uma disposição apropriada por uma decisão que encerra um sentido geral para ação, ou seja, a disposição de ânimo é o primeiro fundamento subjetivo para a adoção de máximas. E como máxima é uma "regra universal de acordo com a qual se quer comportar", então a disposição é moralmente boa se a máxima é a adoção da lei moral como

27 Segundo Aguinaldo Pavão (2010): "A máxima fundamental parece se distinguir da Gesinnung apenas na medida em que consideramos que é ela, como objeto da decisão do arbítrio, quem dá origem à Gesinnung (p.119)". É que a máxima fundamental é uma regra que o arbítrio institui para o uso de sua liberdade. Enquanto a disposição de ânimo (Gesinnung) é o intento firme de perseguir o que é instituído nessa regra. Ao contrário do que diz Aguinaldo Pavão, o Heiner F. Klemme diz (1999): "Kant denomina a máxima suprema (não adquirida "no tempo") de nossas ações também de disposição de ânimo [Gesinnung] (...) (p.12)". Considero que a posição de Pavão é a mais apropriada para explicar o uso que Kant faz desses conceitos. 
fundamento de toda a conduta e má se a adoção for baseada no amor próprio.

O que Kant afirma com sua tese de uma propensão "natural" para o mal, é que o homem decidiu tornar-se mal ao tomar como máxima fundamental de sua ação o princípio do amor próprio e não o comando do imperativo categórico. Kant [1793] (2008) diz:

Assim, pois, para chamar mau a um homem, haveria que poder inferir-se de algumas ações conscientemente más, e inclusive de uma só, a priori uma máxima má subjacente, e desta um fundamento, universalmente presente no sujeito, de todas as máximas particulares moralmente más, fundamento esse que, por seu turno, é também uma máxima (p.26-27).

A máxima fundamental é uma regra geral de conduta que o homem institui para si. Essa regra, ou é o amor próprio, ou é a lei moral. Com a tese que o homem é mal por natureza ou que o mal é radical na espécie humana, é afirmado, por Kant [1793] (2008), que os homens instituíram como regra de suas condutas a subordinação da lei moral ao amor próprio, produzindo um sentido inverso do que é exigido no dever. Ou tomamos como máxima a lei moral, ou tomamos como máxima o amor próprio. A máxima precede enquanto intenção ao ato. Quando tomamos como máxima da ação a lei moral, a ação é boa, enquanto que, quando tomamos como máxima de nossas ações o princípio do amor próprio, as nossas ações resultantes dessa máxima são más. Segundo Kant [1793] (2008): "Mas, em geral, interessa (...) não admitir, enquanto for possível, nenhum termo médio moral (...) (p.28)". Não é admitido nenhum termo médio. Ou a ação é boa ou é má. Quanto à máxima, ou o homem é bom porque tomou como máxima da ação a lei moral, ou é mau e inverteu o dever moral.

A questão é que Kant afirma que o homem é propenso ao mal por “natureza". Como a natureza diz respeito ao uso geral de nosso arbítrio, é preciso que possamos compreender a presente proposição ("o homem é mau por natureza”). A propensão é um ato de liberdade. Segundo Loparic (2007): "Como é adquirida uma disposição ou uma propensão boa? Por um ato que precede e torna possíveis todos os atos moralmente bons. Como é contraída uma propensão má? Por um ato que precede e possibilita todos os atos moralmente maus (p.88)". Ato pode ser compreendido de dois modos ${ }^{28}$. O

28Segundo Kant [1793] (2008): "Mas a expressão "um ato" em geral pode aplicar-se tanto ao uso da liberdade, pelo qual é acolhida no arbítrio a máxima suprema (conforme ou 
primeiro é aplicado à liberdade, pela qual assumimos uma máxima moralmente boa ou má (tem a ver com intenções e, portanto, não pode ser apresentado na experiência); o segundo são as próprias ações que se realizam de acordo com aquela máxima, tais como elas se dão na experiência. Propensão é um "ato" no primeiro sentido. Portanto, não é possível colhermos o fundamento do mal na experiência. É possível sermos louvados como bons diante de todos, mesmo que nossa máxima interna já tenha decaído no amor próprio e não sejamos "bons" de fato.

A propensão pode ser dividida em três graus: 1) fraqueza do coração ou da natureza humana. Essa consiste na falta de capacidade de fazer o bem, mesmo sabendo que deve fazê-lo; 2) a tendência de misturar a lei moral com outros fundamentos, ou seja, a impureza. Quando, apesar da lei moral ser motivo da ação, ela não é ainda o único motivo ou motivo suficiente, somos considerados impuros porque misturamos os motivos e não ficamos apenas com a lei moral; 3) Inclinação para assumir motivos diferentes dos postos pela lei moral ou maldade do coração (corrupção da vontade humana). As duas primeiras são impremeditadas e a última consiste em enganar-se a si próprio sobre os verdadeiros motivos de sua vontade, mesmo que os atos resultantes de máximas más aparentem o contrário. Somos culpados de tal propensão para o mal. Por isso, o mal pode nos ser imputado.

Segundo Kant [1793] (2008):

Esta culpa inata (reatus) - que assim se chama porque se deixa perceber tão cedo como no homem se manifesta o uso da liberdade e deve, no entanto, ter dimanado da liberdade e, por isso, lhe pode ser imputada - pode ajuizar-se, nos seus dois primeiros graus (o da fragilidade e o da impureza), como culpa impremeditada (culpa), mas no terceiro, como premeditada (dolus), e tem por carácter ser uma certa perfídia do coração humano (dolusmalus), que consiste em enganar-se a si mesmo acerca das intenções próprias boas ou más e, contanto que as ações não tenham por consequência o mal que, segundo as suas máximas, decerto poderiam ter, em não se inquietar por mor da sua disposição de ânimo, mas antes em se considerar justificado perante a lei (p.44).

A culpa inata é a nossa propensão para o mal nos seus três graus (fraqueza da natureza humana, impureza do coração e perversidade do coração). Essa

adversa à lei), como também àquele em que as próprias ações (segundo a sua matéria, i.e., no tocante aos objetos do arbítrio) se levam a cabo de acordo com aquela máxima. A inclinação para o mal é, pois, um ato no primeiro significado (peccatumoriginarium) e, ao mesmo tempo, o fundamento formal de todo o ato (...) (2008, p.37)". 
culpa só pode ser denominada como tal na medida em que a liberdade seja base da propensão para o mal, por isso, a expressão "deve ter dimanado da liberdade". Que a culpa seja inata significa que a culpa não foi adquirida no tempo, mas numa ordem anterior ao tempo. A culpa tem origem numa decisão livre. Por isso, a espécie humana tem uma culpa inata. Para Kant [1793] (2008), não basta que nossas ações não causem o mal como sua consequência, o que importa é a máxima que o agente da ação tomou para si antes de toda ação. O que fica confuso é a afirmação de que os dois primeiros graus (fraqueza da natureza e impureza) sejam considerados como "culpa impremeditada". De que modo podemos ser culpados de algo impremeditado? Kant não responde, mas o que nos interessa é o fato de Kant insistir na liberdade da vontade, mesmo em face de uma propensão da natureza humana para o mal.

Toda propensão é física ou moral. Com o assunto em questão, não haveremos de ver a propensão física, mas sim a propensão moral. Uma propensão para o mal só pode estar situada no arbítrio e, portanto, não pode ser uma propensão física. Enquanto seres naturais, não somos nem moralmente maus, nem moralmente bons. Por isso, essa propensão não pode ser colocada na sensibilidade e nas inclinações e desejos daí resultantes. Segundo Giacóia (1998), a propensão para o mal não pode ter fundamento na sensibilidade, 1) porque ela só se relaciona indiretamente com ele, dado que a propensão para o mal moral está intimamente ligada à nossa liberdade; 2) Porque é inata no sentido comum da concepção, que colocaria a propensão na sensibilidade e anularia o ato de liberdade como fundamento dessa propensão; 3) Não pode ser deduzido de uma "propensão para o mal" uma anulação da razão moralmente legisladora. A lei moral é um factum da razão e somente por meio desse factum é possível julgarmos ações moralmente boas ou más. É impossível uma pessoa moralmente neutra, ainda que suas potências morais estejam corrompidas na sua raiz. O mal moral deve ser imputado ao homem enquanto ser livre, o que já pressupõe que a lei moral é uma lei que impõe a necessidade prática de agir comandado por ela, ainda que o homem seja propenso a tomar outros motivos para sua vontade. Nas ações humanas, o mal não é algo desejado por si mesmo, sem a intenção de alcançar algum objetivo. O homem age por representações de leis que ele coloca para si mesmo, ainda que essas leis sejam baseadas no amor próprio. No caso de um ser que escolhe 
o mal pelo mal, tratar-se-ia de uma vontade não humana. Em vez disso, a maldade nas ações humanas se manifesta na medida em que, buscando alcançar determinados fins e satisfazer determinados desejos, adotam máximas moralmente condenáveis.

Segundo Herrero (1991): “Como esse fundamento tem que ser um ato de liberdade, a propensão para o mal é vista já como o mal e não apenas como seu pressuposto. Por isso, Kant diz que o homem é mau por natureza (Herrero, 1991, p.80)". Essa afirmação nos deixa perplexo. Parece haver uma mudança de perspectiva na abordagem dessa questão. Com efeito, foi dito que só sou plenamente livre quando ajo moralmente, as ações moralmente más não poderiam se ligar à liberdade. As ações moralmente más têm de estar em alguma relação com a lei moral, já que apenas no contexto da lei que as decisões são possíveis como um produto da liberdade, dada a necessidade de poderem ser imputadas. A propensão para o mal é inerente à natureza humana e nós somos livres, mesmo diante disso. Livres porque a propensão para o mal é um ato da liberdade que subordina a lei moral a princípios contrários a ela. Se antes foram necessários os postulados de Deus e imortalidade da alma por causa de uma carência subjetiva, agora diante da propensão para o mal radicado na natureza humana, o estabelecimento do sumo bem parece ser impossível, já que a propensão para o mal na natureza humana perverte livremente o dever moral. A liberdade deve ser de acordo com a lei moral e agora ela se entrega ao servilismo.

Situar a origem do mal moral na razão (faculdade de determinação do arbítrio em geral) é dizer que a raça humana se decidiu por fundamentos determinantes do amor próprio. Kant faz aqui uma referência à representação bíblica do mito do Éden. Segundo ele, é conveniente dizer que o mal chegou a nós pelos primeiros pais (Adão e Eva). Isso não significa que Kant tenha aceitado a ideia cristã, segundo a qual a culpa tenha sido imputada em nós antes do nascimento porque Adão e Eva pecaram. Segundo a interpretação tradicional desse mito, a nossa propensão para o mal é uma herança adâmica (procedente do primeiro homem). Is so significaria, de acordo com a filosofia moral de Kant, uma heteronomia para a vontade, na medida em que a nossa culpa do pecado não poderia ser imputada, já que quem pecou foi outrem e não o culpado. O que Kant entende é que, assim como os nossos primeiros pais pecaram, assim também nós o fizemos. Adão e Eva foram seduzidos e 
pecaram, mas poderiam ter tomado outra opção. Kant diz que em toda ação tem que ser pressuposto um estado de inocência (liberdade do arbítrio). Esse estado de inocência é a possibilidade que se abre sempre que uma situação concreta nos obriga a decidir, ou pela lei moral ou pelo amor próprio. Se pecarmos é porque tomamos a decisão ${ }^{29}$ para que nos tornássemos culpados. O resultado é que o homem, mesmo sendo livre em sua constituição racional, optou pelo mal moral. Assumiu para si máximas imorais e desobedeceu o comando do imperativo categórico .Segundo Kant [1793] (2008), a propensão para o mal é universal. Uma prova formal é dispensável ${ }^{30}$, já que os exemplos na história provam que a maldade acompanha a decisão humana em toda a história da humanidade. Segundo Herrero (1991): “Aqui não basta a boa vontade dos indivíduos tomados isoladamente. Tampouco uma legislação que impedisse por coação as más ações dos outros, porque a moralidade ou é livre ou não é moralidade (p.48)". Não há um só homem que seja isento de tal culpa moral. Segundo Kant [1793] (2008):

Por conseguinte, o homem (inclusive o melhor) (...) faz dos móbiles do amor de si e das inclinações deste a condição do seguimento da lei moral, quando, pelo contrário, é a última que, enquanto condição suprema da satisfação do primeiro, se deveria admitir como motivo único na máxima universal do arbítrio (p.42).

O mal só pode ser imputado ao homem, porque ele mesmo adotou, como máxima de suas condutas, o princípio do amor próprio, e subordinou impropriamente os motivos morais aos motivos não morais. O problema é que agora a possibilidade de realização do sumo bem sofre mais um ataque. Se a nossa finitude já era em si mesma uma barreira para a promoção do sumo bem,

29Segundo Kant [1793]: “Toda a ação má, se se buscar a sua origem racional, deve ser considerada como se o homem tivesse imediatamente incorrido nela a partir do estado de inocência. Com efeito, fosse qual fosse o seu comportamento anterior e quaisquer que tenham sido as causas naturais que nele tiveram influência, quer se encontrem dentro ou fora dele, a sua ação é, apesar de tudo, livre e não está determinada por nenhuma destas causas, portanto, pode e deve ser sempre julgada como um uso originário do seu arbítrio (p.46-47)".

30Segundo Kant [1793] (2008) “Ora a prova formal de que semelhante propensão corrupta tem de estar radicada no homem podemos a nós poupá-la em vista da multidão de exemplos gritantes que, nos atos dos homens, a experiência põe diante dos olhos (p.3839)". O que Kant não deixa de frisar a respeito disso é que não podemos encontrar na experiência o que origina o mal, dado que o moralmente bom ou moralmente mal são resultados de máximas que adotamos como regra de nosso agir. Entendido isso, podemos olhar as multidões de exemplos do quanto o homem está em um estado ético natural de desacordo com a lei moral. 
e em vista disso foram necessários os postulados necessários para a realização do sumo bem, agora a questão se tornou ainda mais complicada. O homem decidiu fazer o uso de sua liberdade contra a moralidade.

Se o homem decidiu fazer o uso de sua liberdade contra a lei moral, isso não pode significar que em si mesmo (antes da decisão) aquilo que constitui o homem enquanto tal, a saber, as suas disposições originárias são originariamente más. As disposições são originariamente boas (não se opõem à moral). Disposições são originais (essenciais) quando pertencem necessariamente à constituição do homem, e contingentes àquelas que só o pertencem acidentalmente. Conforme Kant [1793] (2008):

Quando se diz que ele foi criado bom, tal nada mais pode significar do que foi criado para o bem, e a disposição originária do homem é boa; não o é ainda, por isso, o homem, mas, conforme admita ou não na sua máxima os motivos impulsores que tal disposição encerra (o que se deve deixar inteiramente à sua livre eleição), é quem faz que ele próprio seja bom ou mau (p.50).

Kant faz referência apenas às disposições que se referem ao arbítrio e ou à faculdade de desejar. As disposições originárias são, para Kant [1793] (2008), as seguintes: 1) A animalidade, que é uma disposição do homem enquanto é ser vivo; 2) Disposição para a humanidade enquanto o homem é um ser vivo e racional; 3) E sua disposição para a personalidade enquanto o homem é um ser moral ou um ser que se pode imputar ações (um ser livre). A primeira disposição pode ser dividida em três fins a que se propõe: o impulso para a preservação de si próprio, propagação de sua espécie por meio do impulso ao sexo e o impulso para viver em sociedade. Em tal disposição podem resultar diversos vícios. Segundo Kant [1793] (2008): "Podem chamar-se vícios da brutalidade da natureza e denominam-se, no seu mais intenso desvio do fim natural, vícios bestiais: os vícios da gula, da luxúria e da selvagem ausência de lei (na relação com outros homens) (p.32)”. A segunda disposição, assim como a primeira, pode ser dita, com vistas à preservação de si próprio, mas apenas na medida em que a razão compara a nossa situação com a dos outros e, por consequência disso, uma necessidade de ser reconhecido diante de todos como igual. Entretanto, dessa segunda disposição, podem ser também enxertados vícios. Kant [1793] (2008) diz: “(..) daí surge gradualmente um desejo injusto de adquirir para si essa superioridade sobre outros. Aqui, a 
saber, na inveja e na rivalidade podem implantar-se os maiores vícios de hostilidades secretas ou abertas contra todos (...) (p.33)". Com relação à disposição à personalidade é a nossa disposição para tomar a lei moral como motivo verdadeiro de nossa vontade. Segundo Kant [1793] (2008):

A mera ideia da lei moral, com o respeito dela inseparável, não pode em justiça denominar-se uma disposição para a personalidade; é a própria personalidade (a ideia da humanidade considerada de modo plenamente intelectual). Mas o fundamento subjectivo para admitirmos nas nossas máximas esta reverência como móbil parece ser um aditamento à personalidade e merecer, por isso, o nome de uma disposição em vista dela (2008, p.33-34).

O respeito pela lei moral é o fundamento subjetivo da objetividade da lei moral. Nesse sentido, a ideia da lei moral e o respeito a ela unido são a própria personalidade moral da humanidade. Entretanto, o fato de termos um motivo no respeito pela lei moral, não significa que tenhamos tomado como máxima de nossas condutas o dever moral. Em vista disso, é que podemos falar de uma disposição para ela.

\subsection{A possibilidade de conversão moral}

A pergunta pertinente para darmos prosseguimento ao trabalho é a seguinte: como o homem, depois de livremente adotar máximas contrárias ao dever, pode restabelecer suas disposições originárias para o cumprimento do dever moral? A vontade terrestre (humana) decidiu subverter o mandamento moral e tomar para si uma máxima que não está subordinada à lei moral. O que fazer para que uma árvore má produza bons frutos? O que fazer diante do enigma de uma liberdade que se insurge contra si mesma? Uma liberdade que se insurge contra si já não é liberdade. Mas se foi a minha escolha que me colocou no mal moral, talvez por meio de uma outra escolha eu possa retornar para o caminho do bem.

Existe uma culpa que o homem não poderá extirpar, na medida em que é radical na natureza humana. Essa culpa decorre de uma livre adoção de máximas contrárias ao dever moral. Por isso, a culpa é imputável. Que o homem comece pelo mal já é um pressuposto. Caímos no pecado (palavra religiosa para designar um desvio da lei moral) porque fizemos uso ilícito de nossa liberdade. Entretanto, como a disposição para a personalidade não para 
de nos ordenar: “sejam homens e mulheres melhores 31 ", então a propensão natural para o mal não encerrou toda a semente do bem em nós. E se o dever ainda reverbera por meio do sentimento de respeito, o mal nos pode ser imputado. Se o mal nos pode ser imputado, então é pressuposto que, se nós optamos livremente pelo mal, podemos, com base no mesmo pressuposto, optar pelo seu inverso, o bem (uma disposição determinada pela lei moral). Temos que obedecer ao imperativo categórico e sairmos do mal. O homem não é mal originariamente. Originariamente, como foi dito acima, somos bons (nada em nós se opõe ao dever moral). O mesmo ato livre que o enfraqueceu moralmente pode ser repetido para restabelecer a força do bem como horizonte de nossas ações, já que se trata de restabelecer uma disposição que em si mesma sempre foi boa.

A disposição de ânimo precisa passar por uma revolução, na medida em que é necessário um novo modo de pensar que tome o dever moral como horizonte determinante de suas ações. Não se trata de uma revolução que possa ser vista como um fenômeno externo. A revolução é um acontecimento interno da consciência que decide sair do mal para o bem. Uma revolução na disposição de ânimo significa que um propósito firme e inabalável de seguir a lei moral, que foi assumida nas máximas, é o fundamento do esforço posterior e sincero para cumprir o dever. Segundo Kant [1793] (2008):

Isto é: quando o homem inverte o fundamento supremo das suas máximas, pelas quais era um homem mau, graças a uma única decisão imutável (e se reveste assim de um homem novo), é nessa medida, segundo o princípio e o modo de pensar, um sujeito susceptível do bem, mas só no contínuo agir e devir será um homem bom (...) (2008, p.53).

É com a adoção da máxima fundamental da moral que o homem entra no progresso que o retira da propensão para o mal e o coloca no caminho do bem. Deus, segundo Kant, é aquele que julga segundo pode ver no coração dos homens ${ }^{32}$. Que os homens sejam falhos, já é pressuposto pela culpa inata, mas

31 Segundo Kant [1793] (2008): "Efetivamente, não obstante a queda, ressoa sem diminuição na nossa alma o mandamento: devemos tornar-nos homens melhores; devemos, portanto, também poder fazê-lo, inclusive se o que conseguimos fazer houvesse de por si só ser insuficiente e nos tornássemos assim apenas susceptíveis de uma assistência superior para nós imperscrutável (p.51)".

32 Segundo Kant [1793] (2008): "Todas as expiações, sejam de índole penitencial ou festiva, todas as invocações e glorificações (inclusive a do ideal vicário do filho de Deus) não podem compensar a ausência de tal mudança (...) (p.82)". A tal mudança a que Kant se refere diz respeito à necessidade tomar radicalmente o mandamento moral. Sem esse 
é seu dever sair do mal e rumar cada vez mais para o bem. Deus serve de consolo das reais intenções de um coração contrito e convertido pela razão moral. A decisão de tomar a máxima fundamental da moralidade como fundamento de uma disposição boa (não somente em potência, mas em ato) e disposta para o cumprimento do dever moral é a garantia de que uma intenção moralmente determinada e convertida, que pode desenvolver dentro de si a semente do bem.

Segundo Kant [1793] (2008), o homem, na medida em que é culpado de ter se desviado do bem, mesmo depois de o tomar como máxima fundamental da disposição, não consegue uma adequação entre seu modo de pensar (transformado ao se tomar como máxima fundamental à lei moral) e os fenômenos que resultaram dessa disposição transformada. Esse esforço necessário para que a lei moral se efetive no mundo sensível (por meio de ações adequadas à disposição revolucionada), é em si mesmo, uma punição que provém de sua propensão para o mal, de ter que empreender esforço para agir moralmente. Por isso, o desenvolvimento da meta, que é posta a priori pela razão, se dará gradualmente, através de uma reforma que se desenvolve depois que a disposição originária para o bem seja restabelecida no homem, que tomou para si a lei moral como máxima fundamental de suas ações. Segundo Kant [1793] (2008): “Isto só pode conciliar-se assim: para o modo de pensamento, é necessária a revolução, e por isso deve também ao homem ser possível, mas para o modo do sentido (que opõe obstáculos àquela) requer-se a reforma gradual (p.53)". Do ponto de vista do mundo da liberdade (inteligível), a decisão deve ser tomada e a máxima fundamental da vontade deve ser a lei moral, entretanto, no mundo sensível (que supõe obstáculos) essa revolução produzirá uma reforma gradual. Quando as disposições forem revolucionadas, podemos esperar a ajuda divina. Ajuda divina que nos é desconhecida, por isso devemos fazer o que nos é ordenado a favor de uma reforma cada vez mais ampla para atingir o objetivo supremo da razão prática, a saber, a perfeição moral em sua completude final.

Quando decide abandonar seu estado atual para um moralmente bom e mais desenvolvido, será considerado agradável para Deus ${ }^{33}$. A resposta à pergunta 
“como é possível sermos agradáveis a Deus?" recebe uma resposta simples: tomarmos como máxima fundamental da ação a lei moral e não o amor próprio. Segundo Kant [1793] (2008): "Não obstante, esta intenção, por conter o fundamento do progresso contínuo no complemento dessa deficiência, ocupa, como unidade intelectual do todo, o lugar do ato na sua consumação (p.81)". Mas o fato da disposição de ânimo transformada não significa que todas as ações em sua consumação sejam morais. Não devemos nos esquecer do primeiro capítulo, onde o postulado da imortalidade da alma foi necessário para garantir como possível um progresso rumo ao moralmente bom. E como entrar no bem significa tomar a lei moral como máxima fundamental, então $A$ Religião... [1793] nos explica com mais clareza o processo que dá início ao ato virtuoso, a saber, tomar a lei moral como máxima fundamental. A partir daqui é permitido esperar a felicidade como merecimento pela virtude, mas apenas Deus pode garantir que o virtuoso seja galardoado com a felicidade. No caminho, até um homem bom (enquanto é determinado pela lei moral), comete erros e acertos. Se isso é assim, então a disposição de ânimo moralmente determinada, compreendida como boa, não é ainda a garantia de que todas as ações consumadas sejam conforme essa mesma determinação. A nossa intenção transformada contém o fundamento do progresso contínuo, que na ideia (como unidade intelectual do todo) contém o complemento dessa deficiência. Segundo Kant [1793] (2008): "Quanto à qualidade (já que esta se deve pensar suprassensivelmente fundada) deve e pode ela ser santa e conforme a do seu arquétipo; segundo o grau - como se manifesta nas ações continua a ser sempre deficiente e infinitamente distante da primeira (p.81) (grifo meu)". Enquanto o homem foi transformado na sua intenção para o cumprimento do dever moral (segundo a qualidade) ele pode ser considerado "santo" "agradável a Deus", mas segundo o grau (ações resultantes de uma intenção convertida) ele é ainda "sempre deficiente" e “infinitamente" distante do que propôs como máxima fundamental de suas ações $\mathrm{Na}$ intenção, a pessoa é boa, mas não o é igualmente perfeita nas ações concretas. Entretanto, a intenção "ocupa" o lugar do ato na sua consumação.

Agradar a Deus independe de práticas religiosas estatutárias tais como as rezas, cultos, cerimônias ou qualquer outra prática. Isso não significa, 
entretanto, que o culto seja contra a religião moral, mas apenas que não podemos agradar a Deus por meio de rituais, jejuns ou qualquer outra forma exterior da religião. Segundo Kant [1793] (2008):

(...) podemos até honrar o envoltório que serviu para pôr publicamente em andamento uma doutrina, cuja autenticação se funda num documento que persiste inextinguível em toda a alma e não necessita de milagre algum; contanto que, relativamente ao uso destes relatos históricos, não tomemos como elemento de religião que o saber, a fé e a confissão acerca dos mesmos seja algo com que nós podemos tornar agradáveis a Deus (2008, p.91).

Kant [1793] (2008) faz a partir disso uma distinção entre religião da boa conduta e a religião de petição de favores ${ }^{34}$. Para ele, o homem que pensa agradar a Deus por meio de orações, cultos, jejuns e outras práticas ritualísticas, se engana. O meio de agradar a Deus só é possível se já tenhamos transformado nossa disposição má em uma disposição boa. Se esse homem inverte a ordem entre religião racional e religião positiva e coloca o dispensável no lugar do fundamental, decaindo da religiosidade exigida pela razão, engana-se sobre a religião. A religião de petição de favores chega a pensar numa graça que o retira do mal para o bem, supondo que Deus conceda o seu favor, independente da disposição. Parece que o praticante da religião de petição de favores quer receber o auxílio mesmo que não mereça. Kant [1793] (2008) diz que só podemos esperar o auxílio de Deus depois de nos tornarmos merecedores. Foi mostrado que a felicidade é dada por Deus como consequência da virtude. Os auxílios que Deus possa nos conceder somente virão como consequência de uma disposição de ânimo transformada em sua raiz. Segundo Kant [1793] (2008):

Supondo que para se tornar bom ou melhor seja ainda necessária uma cooperação sobrenatural, e que esta consista unicamente na redução dos obstáculos ou seja também uma assistência positiva, o homem deve, no entanto, tornar-se digno de a receber, e de aceitar esta ajuda (o que não é pouco), acolher na sua máxima um aumento positivo de força, graças ao qual unicamente se torna possível que o bem lhe seja imputado e que ele seja reconhecido como um homem bom (2008, p.50).

34Segundo Kant [1793]: "Mas todas as religiões se podem dividir em: religião da petição de favor (do simples culto), e religião moral, a religião da boa conduta de vida. Segundo a primeira, o homem bajula-se a si mesmo, pensando que Deus o pode fazer eternamente feliz sem que ele tenha necessidade de se tornar um homem melhor (...) (p.57)". 
Com a expressão "tornar-se digno de recebê-la" Kant quer conceder a Deus o poder de influenciar a vontade humana, apenas depois que o homem tenha acolhido a lei moral como máxima fundamental. Tornar-se digno de receber ajuda de Deus pressupõe a tomada como máxima fundamental da lei moral. O dever moral deve ter prioridade em face de uma possível necessidade do auxílio divino. O homem deve fazer tudo o que está no seu poder para agir moralmente, para tornar-se agradável a Deus. Como se dá a relação entre uma disposição transformada por uma adesão fundamental à lei moral e as ações resultantes disso? Para respondermos a essa pergunta, citamos a seguinte afirmação de Kant [1793] (2008):

Isto só pode conciliar-se assim: para o modo de pensamento, é necessária a revolução, e por isso deve também ao homem ser possível, mas para o modo do sentido (que opõe obstáculos àquela) requer-se a reforma gradual. Isto é: quando o homem inverte o fundamento supremo das suas máximas, pelas quais era um homem mau, graças a uma única decisão imutável (e se reveste assim de um homem novo), é nessa medida, segundo o princípio e o modo de pensar, um sujeito susceptível do bem, mas só no contínuo agir e devir será um homem bom; i.e., pode esperar que, com semelhante pureza do princípio que adotou para máxima suprema do seu arbítrio e com a firmeza do mesmo, se encontre no caminho bom (embora estreito) de uma constante progressão do mau para o melhor (2088, p.5354).

A mudança de disposição de ânimo implica numa revolução dessa mesma disposição. Essa revolução é um ato único que muda toda a forma de pensar, restabelecendo nas disposições a lei moral em sua pureza e superioridade. Por um ato de liberdade caímos no mal, e apenas por um novo ato de liberdade é possível o restabelecimento da pureza da lei moral como máxima da vontade. Com essa revolução é uma decisão única, a realização do dever tem início aqui, onde a máxima sofreu uma mudança. As intenções do sujeito sofrem uma mudança radical e o homem novamente pode dizer que está no caminho do bem, e em constante progressão em busca do moralmente bom. Esse percurso que se inicia com a mudança da disposição de ânimo, passa, depois desse ato revolucionário, por uma reforma gradual em direção ao bem. Essa reforma terá como meta a "perfeição moral”. Essa perfeição, no entanto, não é uma meta que poderemos alcançar no tempo histórico. Segundo Kant [1793] (2008): “(...) terá, pois, de a buscar ao longo de toda a sua vida (p.82)”. Por isso, a ideia representada na religião de uma perfeição serve de arquétipo que 
devemos realizar na medida de todas as nossas forças. Esse ideal, portanto, deverá ser perseguido com todas as forças disponíveis ou meios disponíveis, desde que a revolução já tenha acontecido e um novo homem já tenha nascido.

\subsection{O sumo bem comunitário (Igreja invisível) e a igreja visível (histórica ou estatutária)}

O primeiro elemento do sumo bem total, o sumo bem supremo, nos levou ao postulado da imortalidade da alma e garantiu como possível o desenvolvimento moral do sujeito das ações. Com o postulado de Deus, nos foi garantido que, se formos merecedores da felicidade, a felicidade nos será a recompensa. Com a novidade conferida pelo texto A religião (1793), que nos informou que o homem, por um ato livre e inteligível, tomou como máxima fundamental o amor próprio e é culpado por ser propenso ao mal, dado que poderia ter acolhida a lei moral e não a acolheu por amor à felicidade pessoal, insere-se como impedimento ao conceito de sumo bem um novo elemento. É que a propensão para o mal é universal e o esforço de sairmos dela não depende apenas de uma decisão pessoal. Mesmo que tenhamos uma disposição revolucionada pelo dever moral, ainda assim, o estado de natureza ético da sociedade nos assedia e somos tentados a cair no pecado (desobediência à lei moral) a todo o momento. É-nos necessário, nesse esforço de reforma gradual (virtude), criarmos uma comunidade moral para unirmos forças a fim de que possamos tomar como ideia para nossas ações. Com isso é possível?

Com o postulado de Deus, Kant garantiu que é possível a unidade entre natureza e liberdade. A natureza como impedimento à realização do sumo bem é reunida em sua essência com a moralidade, porque Deus é capaz de fazê-lo e fará se formos merecedores de seu fazer. A resolução do problema da realização do sumo bem no mundo foi resolvida através dos postulados, mas ainda é necessário acrescentarmos um elemento à ideia do sumo bem. É que com a universalidade da propensão para o mal, adentramos na necessidade de unirmos forças morais com outros agentes para realização do sumo bem no mundo. Por isso, agora chamaremos (como Kant o fez na obra A religião, em 1793) o sumo bem de sumo bem comunitário.

A humanidade considerada em sua perfeição moral parece, depois de 
sabermos que o homem é propenso ao mal, perder a sua dignidade. Mas a saída do mal moral é um dever de todos, dado que todos os homens são propensos ao mal. Todos precisam de uma conversão revolucionária na forma de pensar, para realização do sumo bem no mundo. A humanidade tem aqui um dever para consigo mesma. Não apenas o dever do agente individual, mas um dever coletivo de formar uma comunidade ética sob leis de virtude no mundo. Segundo Spinelli (2012): "O operar individual, tão enfatizado por ele em suas obras anteriores, cede espaço ao operar individual perante a coletividade, em que não se põe mais em questão a reabilitação do indivíduo isoladamente, mas o aperfeiçoamento do gênero humano conjuntamente (p.37)".

Segundo Herrero (1991): “O homem deve sair do mal. Mas como se concretiza esse dever? O esforço do indivíduo é insuficiente, pois o mal do outro não pode ser superado por mim. O dever é de todos, mas não apenas tomados individualmente (p.97)". Não estamos querendo dizer que o dever da humanidade para consigo mesma seja resultado de nossa propensão para o mal, mas que, assim como a propensão para o mal atinge a todos, assim também o dever de formar uma comunidade adequada ao objeto total da razão prática ( sumo bem comunitário) é um dever de todos e não apenas do agente que se converteu às ordens da lei moral. Logo que o homem está no meio de outros homens ele é assediado por todos os lados. Segundo Kant [1793] (2008): “A inveja, a ânsia de domínio, a avareza, e as inclinações hostis a elas associadas assaltam a sua natureza, em si moderada, logo que se encontra no meio dos homens, e nem sequer é necessário pressupor que esses já estão mergulhados no mal (...) (p.100)". O que Kant quer dizer é que a conversão moral não é suficiente para formar uma comunidade moral, já que a experiência nos informa que o homem está mergulhado no mal.

Assim como num estado de natureza jurídico é pressuposto uma luta de todos contra todos, assim também o estado de natureza ético é de inversão das máximas e naufrágio no pecado. Segundo o filósofo [1793] (2008):

Ora se não pudesse encontrar-se um algum meio de erigir-se uma união de todos verdadeiramente encaminhada à prevenção deste mal e ordenada ao fomento do bem no homem, como uma sociedade consistente e sempre em expansão, que tem em vista simplesmente a manutenção da moralidade e que, com forças unidas, se oporia ao mal, então, por muito que o homem singular pudesse ter feito para subtrair-se ao domínio do mal, este mantê-lo-ia sempre no perigo da recaída sob o seu 
domínio no mal (2008, p.100).

Para sairmos, portanto, do mal, é necessária a união de todos sob leis de virtude, ou seja, sob leis que impomos a nós mesmos, sem a mediação de qualquer outro intermediário que a fantasia humana possa inventar para fugir do dever. O primeiro elemento do sumo bem (a virtude) é um dever de todos e não apenas do agente individual, porque aquele que ainda não tomou a lei moral como máxima de suas ações, não pode contribuir para o fomento do sumo bem comunitário (a comunidade ética). Esse é um dever peculiar, já que não é apenas um dever direcionado ao eu individual, mas à humanidade em geral, portanto é um dever que todos devem realizar. Segundo Kant [1793] (2008): “Temos, pois, aqui um dever de índole peculiar, não dos homens para com os homens, mas do gênero humano para consigo mesmo. Toda a espécie de seres racionais está objetivamente determinada, na ideia, a saber, ao fomento do bem supremo como bem comunitário (p.103)". O sumo bem comunitário é uma antecipação do que o homem deverá viver numa comunidade moral. Essa antecipação racional é a ideia do dever de fomentar o sumo bem comunitário no fenômeno. A ideia que orienta a reforma na conclusão de sua meta. Mesmo que o agente moral aja de tal modo que seu esforço seja todo no sentido da realização de tal comunidade ética, ainda assim, ele não poderia impor, com forças próprias, a mesma disposição de ânimo que orienta suas ações aos outros homens que o rodeiam e o atacam com todo tipo de tentação para a queda no mal moral. Segundo Kant [1793] (2008), a revolução nas disposições é uma mudança no coração que incide numa renúncia do mal e uma tomada da lei moral como máxima fundamental de todas as ações. Nesse horizonte, o homem quer fazer o bem e tem a obrigação de realizar com todas as suas forças o sumo bem mundo. Entretanto, o homem está lançado no estado de natureza ético ${ }^{35}$, onde os homens tomaram para si a máxima do amor próprio como princípio das ações. Segundo Klemme (1999): "Não obstante a recolocação da ordem moral no âmbito dos respectivos indivíduos, que doravante têm uma vontade boa, no âmbito social,

35Para Kant [1793] (2008) o estado de natureza ético é similar ao estado de natureza político. Assim como no estado de natureza político exista uma guerra de todos contra todos, onde cada um dá a si, de forma arbitrária, a total anarquia de princípios de convivência. Segundo Kant [1793]: “(...) assim também o estado de natureza ético é um estado de incessante assédio pelo mal, que se encontra no homem e, ao mesmo tempo, em todos os outros (...) (p.103)". 
o mal exerce seu domínio despótico sobre os homens (p.26)". Por isso Kant [1793] (2008) diz, referindo-se ao homem que tomou a lei moral como máxima fundamental das ações: "Mas nem por isso deixa de estar sempre exposto aos assaltos do princípio do mal; e a fim de afirmar sua liberdade, que é constantemente atacada, deve doravante manter-se sempre preparado para a luta (p.99)”. O homem convertido à lei moral sofreu uma revolução nas disposições, mas o processo pelo qual sua natureza sensível conformar-se-á à revolução será o de reforma gradual. Por isso, ainda que o coração esteja transformado, persiste o dever de se tornar um homem melhor. O processo de saída do mal ainda continuará, e não poderá ser realizado a menos que seja possível a realização da ideia de uma comunidade sob leis de virtude, isto é, a comunidade moral. Segundo Kant [1793] (2008):

Mas porque o sumo bem moral não é realizado apenas mediante o esforço da pessoa singular em ordem à sua perfeição moral, mas exige uma união das pessoas num todo em vista do mesmo fim, em ordem a um sistema de todos os homens bem intencionados, no qual apenas, e graças à sua unidade, se pode realizar o bem moral supremo (...) (2008, p.104).

É preciso encontrar o modo como seja possível que os homens formem uma comunidade ética para resistir aos ataques do mal. Essa comunidade deverá ter em vista à moralidade e nada mais. Sua expansão se dará com vistas à união de todo o gênero humano. Uma união de homens sob leis de virtude. Segundo Kant [1793] (2008): "Só assim se pode esperar uma vitória do princípio bom sobre o mal (p.100)". Kant também chama a esta "comunidade ética”. A pressuposição é que essa comunidade é composta por homens cujo coração foi transformado e a lei moral foi tomada como motivo suficiente do agir. Essa comunidade ética incluiu o mundo e a humanidade moral em uma unidade. Kant [1793] (2008) diz que “(...) o conceito de uma comunidade ética está sempre referido ao ideal de uma totalidade de todos os homens (...) (p.102)". Enquanto é ideal, ela não pode ser encontrada na experiência. O esforço dos homens para realizar o dever de promoção de uma comunidade ética é sempre imperfeito. Como foi dito, ainda que certo grupo se converta ao dever moral, não será possível forçarmos a todos os outros homens a fazerem o mesmo, dado que tal comunidade é uma ideia na qual todo o gênero humano é inserido. Tal comunidade, ainda que seja composta de pessoas bem 
intencionadas (transformadas), essa comunidade caba por ser uma comunidade particular, dado que não poderá inserir toda a humanidade no rol de seus membros, ainda que isso continue como meta. Para Kant [1793] (2008) os homens não conseguem formar uma comunidade ética perfeita, mas apenas uma comunidade particular com a finalidade de alcançar o ideal de uma comunidade perfeita. O máximo que uma sociedade particular consegue atingir é um constante melhoramento com vistas à comunidade ética.

Na comunidade política ou civil, o legislador é o próprio povo, porque uma legislação jurídica brota do princípio racional externo que diz [1793] (2008): “(...) restringir a liberdade de cada um às condições sob as quais pode coexistir com a liberdade de todos os outros segundo uma lei em geral (p.104)". Nesse caso, uma vontade geral do povo deve instituir as leis que conduzirão a sociedade. No caso da comunidade ética, as coisas se dão diferente. Aqui não poderá ser uma lei geral, nascida da vontade geral do povo, que coordenará uma legislação apropriada ao dever moral. As leis jurídicas coagem de fora a fim de preservar a unidade social. O estado jurídico legisla exteriormente e não pode conhecer interiormente. A legislação da comunidade ética tem a função de fomentar a moralidade (que tem a ver com disposições de ânimo) e não a legalidade (que tem a ver com coerção exterior). A sociedade política, no máximo, serve de analogia, mas com o cuidado de não igualar ao invés de só comparar. As leis de uma comunidade histórica são sempre falhas e coagem apenas de fora, sem poder acessar o interior da pessoa humana. Nem mesmo o seu próprio coração é todo conhecido diante de si. Segundo Kant [1793] (2008):

Portanto, só pode conceber-se como legislador supremo de uma comunidade ética um ser relativamente ao qual todos os verdadeiros deveres, portanto, também os éticos, se hão de representar ao mesmo tempo como mandamentos seus; o qual, por isso, deve igualmente ser um conhecedor dos corações, para penetrar no mais íntimo das disposições de ânimo de cada qual e, como deve acontecer em toda comunidade, proporcionar a cada um aquilo que os seus atos merecem (2008, p.105).

Apenas Deus é capaz de sondar todos os nossos segredos e fazer feliz àquele que merece a felicidade (aquele que é virtuoso). O reino moral tem leis que legislam sobre o coração, e a retribuição que cada um merece, por ter sido bom de coração, recairá sobre um ser que é capaz de conhecer o fundo de 
nossas intenções, e retribuir a justiça devida. A legislação humana legisla sobre ações externas e não internas. Importa, portanto, que pensemos uma legislação que provenha de um ser que seja capaz de perscrutar os corações. Esse ser moral é Deus. Por isso, o princípio fundamental de uma comunidade ética é que a lei moral seja tomada como mandamento divino, e que esse critério seja o modo pelo qual Kant empreenderá uma crítica a todas as formas de comunidade que não tendem ao fomento do sumo bem comunitário no mundo. O postulado de Deus aparece aqui mais uma vez. O postulado, tal como já apareceu para nós no capítulo anterior, nos foi necessário porque o objeto total da razão prática não poderia ser possível, caso a existência de Deus não se tornasse necessária. Aqui, com a necessidade de um sumo bem comunitário, o postulado da existência de Deus vem ao encontro de duas fragilidades humanas consecutivas. Segundo Spinelli (2012):

(...) no contexto do escrito sobre a religião, ele situou Deus como um legislador moral, para que a partir dessa crença, por um lado, os agentes conferissem mais efetividade à sua união na comunidade ética e, por outro, fosse conservada a possibilidade da avaliação moral das ações (já que um legislador humano seria ineficiente nesse quesito) $(2012$, p.48).

O homem não pode conhecer os corações e, por isso, não pode legislar moralmente sobre outros homens. Ele tem a tendência em seu estado de natureza ético de tomar o outro como meio e não como fim em si mesmo. Segundo Herrero (1991): "Só o perscrutador dos corações pode ver o grau de moralidade dos indivíduos e ser legislador deles (p.101)”. A legislação humana atinge apenas o fenômeno e não as intenções. Apenas Deus pode ser o governante supremo de uma comunidade verdadeiramente moral. Isso não significa que a lei moral proceda de Deus, mas que com a inserção de Deus para realizar o sumo bem comunitário, a lei moral seja tomada como se fosse mandamento divino, pois já sabemos que os deveres para com Deus são deveres para conosco mesmos. Com a lei moral entendida como mandamento moral de Deus, colocamos, não só a lei moral no patamar da sacralidade, mas também, a existência de Deus fica restringida à utilidade moral. Só na medida em que a fé na existência de Deus é resultado da consciência da subordinação das inclinações ao comando da lei moral, é que podemos compreender, como consequência, essa mesma lei como mandamento divino. Somente assim, segundo Kant, é possível compreendermos a religião como consequência da 
moral.

A novidade no postulado de Deus em A Religião consiste no fato de ele ser tomado aqui para garantir que o sumo bem comunitário seja possível. Entretanto, frisamos que, com isso, não queremos isentar o homem do dever de promover o sumo bem comunitário. Ao contrário, o homem deve promovêlo e não deixar para Deus o que pode fazer. A assistência divina só poderá ser esperada se fizermos tudo o que nos for possível fazer para merecer a sua ajuda. Não temos o direito de nos determos em elucubrações de como Deus agirá em favor da promoção do sumo bem comunitário. O perigo de nos determos em coisas sobre as quais nunca podemos saber desviará o verdadeiro motivo de uma fé moral em Deus. Fé essa que deve estar amparada no dever moral e não na revelação histórica ou no misticismo, oferecida pela religião estatutária. Apenas aqui é possível falar de uma fé racional ou moral. Qualquer outro conteúdo religioso que não esteja a serviço da promoção do sumo bem comunitário precisa adequar-se à legislação racional da razão. Mas se os homens são ordenados a realizar o sumo bem comunitário e, ainda assim, são incapazes de fazê-lo, então apenas devemos fazer o que nos é possível fazer e ordenado pela lei moral.

A comunidade ética é uma ideia da razão. Como ideia, ela não pode ser encontrada na experiência. Por isso, a comunidade ética é chamada de igreja invisível. Segundo Kant [1793] (2008):

Uma comunidade ética sob legislação divina é uma igreja, que, na medida em que não é nenhum objeto da experiência possível, se chama igreja invisível (uma mera ideia da união de todos os homens retos sob o governo divino imediato, mas moral, do mundo, tal como serve de arquétipo às que devem ser fundadas por homens) (2008, p.107).

Essa igreja é composta de pessoas íntegras moralmente. A legislação provém de Deus, mas só na medida em que o dever o põe para realizar o seu objeto supremo. Por isso, é dito na citação acima que o governo de Deus é imediato, mas é ao mesmo tempo moral. A ideia de uma igreja invisível não pode ser realizada pelos homens, mas é o seu dever fazerem tudo o que podem, com todas as suas forças, para promoverem o sumo bem comunitário no mundo. Os homens devem trazer o reino de Deus para a terra. Eles devem se esforçar para a promoção dessa ideia no fenômeno. A ideia de uma comunidade ética serve de arquétipo para as comunidades que são fundadas 
pelos homens. A expressão "serve como arquétipo" resulta de que todas as comunidades humanas são imperfeitas e devem tender para o perfeito (a igreja invisível como arquétipo). A igreja visível é subordinada à invisível uma vez que se guia pelo ideal por ela proposto. Nenhuma comunidade humana tem consistência em si mesma. Ela deve se remeter ao seu arquétipo (comunidade ética) e se desenvolver para ser como ele é na ideia. A ideia é posta como modelo a ser seguido. O sumo bem comunitário é uma ideia da razão que tem por finalidade o desenvolvimento moral dos homens.

Os homens criam igrejas visíveis e não a verdadeira igreja invisível. Segundo Kant [1793] (2008): “A igreja visível é a união efetiva dos homens num todo que concorda com esse ideal (p.107)”. Entretanto, essa união está ainda distante de ser efetivada tal como é ordenada pelo ideal de uma igreja invisível. Kant [1793] (2008), no entanto, deixou claro que toda igreja humana deverá, para representar o reino de Deus na terra, ser erigida por princípios promanados da moral, que devem orientar toda e qualquer tentativa de organizar uma igreja visível. Uma comunidade ética sob leis de virtude, cujo ser supremo é capaz de retribuir a cada um de acordo com o seu merecimento, deve ser compreendida como igreja invisível. Esses princípios morais pertencem a uma igreja invisível e a igreja visível deve tê-los como meta de suas práticas. Segundo Höffe (2005) diz: “A igreja invisível como povo de Deus, visto que é numericamente única; ela é santa, porque como comunidade segundo leis de virtude é determinada por completa integridade e pureza moral; ela é apostólica, visto que sua constituição, a legislação moral, é imutável (p.288)". Também segundo Kant [1793] (2008), “a verdadeira igreja visível é aquela que representa o reino de Deus (moral) na terra (...) (p.107)". Vamos dividir as características da igreja invisível (que deve servir de requisito a toda igreja visível) por meio de itens: 1) Universalidade, que já compreende uma unidade. Os diversos credos de fé não indicam que, com isso, existam várias religiões. Há somente uma religião verdadeira ${ }^{36}$, a saber, a religião moral; 2) A qualidade deve ser a pureza das intenções morais de seus

36 Segundo Kant [1793] (2008): “Há somente uma (verdadeira) religião; mas pode haver múltiplos tipos de fé. - Pode, no entanto, acrescentar-se que nas diversas Igrejas separadas umas das outras pela diversidade dos seus modos de crença é possível deparar com uma única e mesma verdadeira religião. - É, pois, mais conveniente (e também, de facto, mais usual) afirmar 'este homem é desta ou daquela fé (judaica, maometana, cristã, católica, luterana)' do que dizer 'É desta ou daquela religião' (p.113-114)”. 
membros, eliminando doutrinas e práticas ritualísticas que não estão de acordo com a moral; 3) A imutabilidade quanto à sua constituição. Isso não quer dizer que uma religião deva permanecer imutável sob princípios imorais. O que a imutabilidade requer é que os princípios da religião sejam racionalizados, para que não seja possível uma mudança de seus conteúdos doutrinários por falta de racionalidade (adequação ao imperativo categórico). Höffe (2005) deixou de mencionar um quarto princípio $\left.{ }^{37}: 4\right)$ A relação sob o princípio da liberdade. Uma religião que carrega as pessoas com doutrinas estatutárias, que comprometem e até rejeitam a liberdade, deve ser considerada falsa. A igreja invisível, tem, portanto, primazia sobre a religião visível. A religião racional tem, portanto, segundo Kant, primazia sobre a religião positiva.

\subsection{A crítica de Kant à religião estatutária}

A história da realização do sumo bem comunitário encontra um impedimento na história, dado que entre a ideia de sumo bem comunitário e as comunidades que se apresentam como fenômeno humano, há um abismo, que só pode ser superado por Deus. As igrejas formadas pelos homens pressupõem um estatuto, elas não realizam a ideia de uma igreja invisível, por isso devem ceder lugar a uma religião moral. Segundo Kant [1793] (2008): "Os envoltórios sob os quais se formou primeiro o embrião em vista do homem devem despir-se, se ele agora deve vir à luz do dia (p.127)”. Os envoltórios são as representações religiosas (símbolos religiosos) "os quais se formou primeiro embrião". A metáfora do embrião diz que os homens erigem uma religião estatutária antes da religião racional, mas é uma exigência da razão que os envoltórios (símbolos religiosos) sejam substituídos pela ideia de religião moral. Com relação a esse assunto, Kant [1793] ainda diz: "Enquanto ele (gênero humano) era uma criança, tinha inteligência de criança, e sabia lidar com estatutos (...), mas agora torna-se homem, despede-se do que é infantil (p.127)". A relação com estatutos só existe na medida em que ainda não chegamos à realização da ideia racional de religião. Ainda pensamos

37 Segundo Kant [1793] (2008): “A relação sob o princípio da liberdade, tanto a relação interna dos seus membros entre si como a externa da Igreja com o poder político, ambas as coisas num Estado livre (...) (p.108)". 
como crianças quando erigimos religiões estatutárias, mas devemos nos tornar homens para vermos a luz do dia (a ideia da religião racional). Como se estabelece essa distinção entre religião verdadeira e religião estatutária?

A realização é dever do homem, mas a efetivação da ideia não é realizada pelas religiões, por isso, a realização concreta do sumo bem comunitário é obra de Deus e não do homem. Segundo Herrero (1991): “Mas onde a própria ação do homem não basta para tornar efetivo o soberano bem comunitário, aí a razão está autorizada a admitir o complemento necessário por parte de Deus (p.102)". Apesar de o homem ter que fazer tudo o que puder para cumprir os seus deveres, mesmo aqueles que não estão ao alcance de suas mãos (na medida em que só o podemos colocar como horizonte de nossos esforços morais), para realizá-lo plenamente (como no caso do sumo bem comunitário), é o seu dever empreender todo esforço (virtude) para realizar a ideia de sumo bem comunitário. Segundo Herrero (1991):

A liberdade deve realizar-se na história (...). Ora, a lei moral prescreve a realização do reino dos fins pela promoção do soberano bem. A ideia de soberano bem deve ser realizada no fenômeno. E enquanto a liberdade se consuma na religião, deve realizar o soberano bem comunitário na história (pg.150).

A história concreta das religiões, ou seja, tais como elas se apresentam na história empírica, não poderá servir de meio, a partir do qual, se encontre, efetivamente, a realização da ideia de uma religião pura. O que é afirmado, por Kant, é que as religiões visíveis precisam ser meios para a verdadeira religião da razão. Isso obrigará Kant a conceber uma "religião nos limites da simples razão". A religião nos limites da simples razão não é a religião pura, que promana única e exclusivamente da razão, mas também de elementos da história e cultura do espaço e lugar no qual ela foi formada. Areligião nos limites da simples razão tem, ao menos, uma compatibilidade entre os seus princípios de fé e o princípio racional da religião verdadeira. Segundo Herrero (1991), Kant empreenderá uma crítica a toda as formas de religiões estatutárias, realizando, para isso, uma reinterpretação dos conteúdos da fé revelada, para ver se os tais conteúdos estão em acordo ou desacordo com a moral. Caso não estejam de acordo com a moral devem esforçar-se para tal, e quando de acordo com a religião moral, devem libertar-se de todas as formas estatutárias da religião.Todas as religiões estão submetidas a priori ao conceito de religião verdadeira. Entretanto, algumas estão ainda num processo 
rudimentar, e outras num processo mais desenvolvido para atingir a igreja invisível no mundo. Mas ambas, tanto as que são consideradas mais desenvolvidas em relação às outras, quanto as que são menos desenvolvidas (do ponto de vista moral), carecem de compatibilidade plena com a religião moral. A religião estatutária (igreja visível) é sempre um meio para atingir a verdadeira religião. Portanto, se uma proposição de fé não está de acordo com a moral, deve ser substituída por outra mais adequada. As comunidades humanas devem avançar moralmente até chegar ao desenvolvimento máximo, a saber, a comunidade ética sob leis de virtude, comandada por um legislador justo e que pode retribuir a cada um de acordo com suas obras. Mas a história concreta da religião mostra que esse ideal ainda não se realizou. Por isso, a distinção entre religião estatutária e religião racional é fundamental para não se perder o conceito de uma religião verdadeira. As instituições religiosas perdem-se em doutrinas que não contribuem para o desenvolvimento do homem como fim em si mesmo. O homem, nessa forma religiosa, confunde e inverte a ordem dos fatores. Onde a moral deveria ser estabelecida com prioridade, é posta a revelação como fundamento da religiosidade. No pensamento de Kant, a religião promana da moral e isso não pode ser esquecido pelo religioso. Se a religião não torna homens moralmente melhores, elas não servem à sua verdadeira função, que é ser um meio para instauração do reino de Deus na Terra (termo teológico para dizer sumo bem comunitário). Segundo Omar Perez (2007):

Ciertamente, una iglesia universal (aunque invisible) es el único modo en que podemos representarnos racionalmente una comunidad de espíritus, donde la comunicación no se da a través del éxtasis místico ni por medio de la imposición estatuaria, sino como consecuencia necesaria del deber moral $(\text { p. } 94)^{38}$.

Segundo Kant [1793]: “Toda a espécie de seres racionais está objetivamente determinada, na ideia, a saber, ao fomento do bem supremo como bem comunitário (p.103)". Entretanto, o afazer dos homens para promover o sumo bem comunitário é marcado por desvios. As religiões

38“Certamente, uma igreja universal (ainda que invisível) é o único modo em que podemos representar racionalmente uma comunidade de espíritos, onde a comunicação não se dá através de êxtases místicos nem por medo da imposição estatutária, senão comoconsequência necessária do dever moral" ( tradução do autor). 
estatutárias estão baseadas em revelações. Kant sabe que a verdadeira religião (pelo menos o que ele acha que é a verdadeira religião) não deve ser confundida com nenhuma instituição humana concreta. As diversas religiões são apenas meios de expressar a verdadeira religião. Enquanto meios, elas devem realizar a igreja invisível na sua forma visível de se organizar. O problema é que esse meio adequado de representar o reino de Deus na terra é carente de uma esfera mais ampla de compreensão. Acredita-se, por exemplo, em doutrinas que estão totalmente contra a lei moral, como se fossem leis de Deus. Segundo Kant [1781] (1999):

(...) somente a razão, e não um pretenso e misterioso sentido da verdade, nenhuma intuição esfuziante sob o nome de fé, na qual se possam enxertar a tradição ou a Revelação, sem a consonância da razão, mas, (...) apenas a autêntica e pura razão humana é que, de facto, se afigura necessária e recomendável para servir de orientação (...) (1999, p.4).

A razão é a única que pode fornecer um conceito de religião verdadeiro. A religião revelada, no máximo, pode ser um veículo para a moral. Com a diferença entre a igreja visível e a igreja invisível, temos como resultado também uma distinção entre fé moral (fé racional) e uma fé histórica (fé estatutária). O primeiro tipo de fé promana da necessidade de um Deus para realizar um mundo moral para os homens viverem sob leis éticas numa comunidade ética; o segundo tipo de fé está baseado na revelação (pública ou privada). Sobre isso, Kant [1781] (2008) diz que "nenhuma intuição esfuziante sob o nome de fé" pode substituir o que somente a razão pode fornecer. Uma fé que é enxertada de revelação e tradição, sem uma harmonia com a razão, deve ser considerada uma fé falsa, que não procede da razão. A religião que toma a fé histórica como fundamento de suas representações religiosas deve assumir a religião moral e realizar uma revisão de seus conteúdos. É estabelecida aqui uma submissão da religião estatutária à religião da razão pura. Kant [1793] (2008):

A fé religiosa pura é decerto a única que pode fundar uma Igreja universal; pois é uma simples fé racional que se deixa comunicar a cada qual em vista da convicção, ao passo que uma fé histórica, fundada unicamente em factos, só pode alargar a sua influência até onde conseguem chegar, segundo circunstâncias de tempo e lugar (...) (2008, p.108-109). 
Kant [1793] (2008), com isso, distingue uma fé racional ${ }^{39}$ e uma fé histórica com o fito de estabelecer que a comunicação de uma religião verdadeira, que vale para todos e não se restringe ao tempo e lugar no qual ela foi formada, só pode promanar da moral. A fé racional é uma convicção subjetiva, mas fundada em motivos objetivos (válido para todos). Não cremos em Deus corretamente, segundo Kant, por meio de uma revelação. A revelação que exige apenas uma fé histórica é fraca para comunicar o verdadeiro dever da humanidade para consigo mesma. Orienta-se baseada em "fatos", o que permite apenas que a influência de tal religião permaneça restrita ao lugar e ao tempo de sua criação. A fé racional pode comunicar o seu conteúdo universalmente, porque ele provém da razão e procede da moralidade das disposições. A fé racional e a fé moral são baseadas na necessidade de pressupor um Deus para a realização do objeto posto pela lei moral, a saber, o sumo bem comunitário. Essa fé não equivale à crença histórica; não é um saber; é simples pressuposto, fundado na necessidade do seu uso no propósito prático. Segundo Kant (2002) [1788]: "É o caso de observar aqui que essa necessidade moral é subjetiva, isto é, uma carência, e não objetiva (...) (p.203)". A fé racional é a que está baseada unicamente na razão e não em dados tirados da experiência, ou seja, a fé racional (moral) não tem nada haver com o saber objetivo e teórico, mas é um pressuposto necessário para o campo prático ${ }^{40}$, na medida em que se insere na tentativa de Kant de tornar possível a realização do sumo bem comunitário. Mais do que isso: o conceito de Deus é o meio pelo que Kant coordena, numa unidade, a ação moral e os resultados concretos da mesma na natureza (mesmo que apenas na ideia).

No terceiro capítulo do livro A Religião [1793], o item cinco tem como título: "A constituição de cada Igreja parte sempre de qualquer fé histórica (revelada) que se pode denominar fé eclesial, e esta funda-se, no melhor dos

39Segundo Kant [1786] (2008): “(...) fé racional é a que não se funda em nenhuns outros dados excepto os que estão contidos na razão pura. Toda a fé é, pois, um assentimento subjectivamente suficiente, mas no plano objectivo com consciência da sua insuficiência; portanto, contrapõe-se ao saber (p.12)".

40Segundo Kant [1787] (2008): "Prático é tudo aquilo que é possível através da liberdade (p.475)". E como a liberdade é uma ideia pura da razão, e o que é do campo prático se refere, não a objetos que nos são apresentados na experiência, então só nos resta tomar esse conceito como componente do mundo moral, já que para agir moralmente é necessário pressupor a liberdade da vontade. Portanto, o campo prático, e todos os conceitos implicados nele de maneira pura, remetem-se ao prático e não ao conhecimento teórico. 
casos, numa Escritura sagrada (p.108)". A ideia de religião como um conceito a priori não é constatável na experiência. Na experiência, a ideia de religião assume formas menos desenvolvidas das que o seu conceito exige. O motivo, segundo Kant [1793] é: “(...) uma particular debilidade da natureza humana tem a culpa de nunca se poder contar com essa fé pura tanto como ela merece, a saber, fundar somente nela uma Igreja (p.109)". A debilidade da natureza humana é a causa pela qual o homem "parte sempre de qualquer fé histórica", e no melhor dos casos, essa fé histórica (fé eclesial) funda-se numa escritura. Uma fé revelada na escritura, entre as possibilidades de uma fé histórica, é o meio pelo qual os homens tornam o seu pensamento religioso digno de respeito. As sentenças desse livro permanecem imutáveis, mesmo que seja sacudida por revoluções ${ }^{41}$. Não quero dizer, com isso, que uma escritura sagrada tem valor em si mesma. Os textos devem ser interpretados à luz de uma religião racional. Inclusive Kant [1793] diz que a escritura será melhor interpretada, mesmo se tivermos que mudar o seu sentido literal ${ }^{42}$, à luz da necessidade de perseguir a ideia de uma religião pura. Pois, se um sentido literal é prejudicial ao desenvolvimento moral do homem, então é melhor que encontremos um sentido mais apropriado à moralidade das disposições.

É resultado de uma tendência natural do homem erigir, no lugar da religião pura, uma religião baseada em estatutos, que tem a necessidade de tornar intuíveis os conceitos puros. O homem precisa tornar intuíveis conceitos abstratos para que, por meio de sensificações dos conceitos morais (abstrato), ele possa colher daí o elemento espiritual da religião, a saber, a religião da razão. Como o homem precisa tornar intuível (sensificado) o que é apresentado pela simples razão, o processo pelo qual ele se reúne em uma igreja, começa com uma fé histórica na revelação. Segundo Kant [1793] (2008): "Por consequência, no esforço do homem em vista de uma comunidade ética, a fé eclesial precede naturalmente a fé religiosa pura (...) (p.112) (grifo do autor)". Isso não significa que a religião revelada seja o

41Segundo Kant [1793] (2008): “(...) e a história demonstra que nenhuma fé baseada na Escritura pôde ser exterminada nem sequer pelas mais devastadoras revoluções de Estado, ao passo que a fé fundada na tradição e nas antigas observâncias públicas encontrou simultaneamente a sua ruína na desorganização do Estado (2008, p.113)".

42Segundo Kant [1793] (2008): “Esta interpretação pode, inclusive, parecer-nos muitas vezes forçada quanto ao texto (da revelação), pode, com frequência, sê-lo de facto e, todavia, contanto que seja possível que o texto a aceite, há de preferir-se a uma interpretação literal que ou não contém absolutamente nada para a moralidade, ou atua mesmo contra os móbiles desta última (2008, p.116)". 
modo verdadeiro de uma religião. A religião consiste em tomarmos os nossos deveres como mandamentos divinos porque promana da moral. O homem tem a propensão natural de exigir um elemento sensível para tornar claros os conceitos abstratos da razão. Isso é o motivo pelo qual ele estabelece para si uma religião baseada na revelação. Segundo Kant [1793] (2008):

(...) por causa da necessidade natural de todos os homens de, para os supremos conceitos e fundamentos da razão, exigir sempre algum apoio sensível, alguma corroboração empírica e quejandos (a que, de facto, importa atender no intento de introduzir universalmente uma fé), deve utilizar-se qualquer fé eclesial histórica, que em geral alguém encontra já diante de si (2008, p.115).

As implicações do que é dito na citação acima nos permitem afirmar: 1) É uma necessidade natural de todos os homens terem um apelo sensível para compreender os conceitos supremos, e como o conceito de religião pura é um conceito racional, a formação de uma religião estatutária, bem como os símbolos que expressam uma doutrina ou rito, é um modo de sensificar o conceito supremo de religião; 2) Por isso, o homem começa pela fé histórica. Que o homem comece com a fé histórica, Kant concorda como já foi mostrado, mas que o homem deva permanecer nela é o que Kant não aceita. Pois uma fé racional deve ir, progressivamente, substituindo a fé histórica da revelação. Mas aqui parece haver um problema insolúvel: se como homem, ele tem uma tendência natural de apelar ao sensível para compreender conceitos supremos, então como é possível, que alguma vez na sua vida, ele possa abandonar essa necessidade natural e compreender os conceitos neles mesmos?

Nada institucional pode garantir um acesso a Deus. É nosso dever, segundo Kant, purificar-nos de todas as formas ritualísticas e rumar, cada vez mais, para o cumprimento do dever, onde a comunidade humana e o homem individual possam, junto com o mundo natural, chegar ao patamar de uma moralidade plena. O problema é que Kant diz que o sumo bem comunitário é apenas uma ideia. Enquanto ideia, ele não pode ser encontrado na experiência. Segundo ele [1793] (2008):

A ideia sublime, nunca plenamente alcançável, de uma comunidade ética mingua muito em mãos humanas, a saber, para chegar a ser uma instituição que, capaz em todo o caso de representar somente a forma daquela, está, no tocante aos meios de erigir semelhante todo, muito restringida sob condições da natureza sensível do homem (2008, p.106). 
Kant diz que devemos fundar uma comunidade ética e que, nesse caminho, cometeremos vários erros e desvios, pela nossa condição sensível, de ter que tornar sensível o conceito puro de religião. Mas devemos insistir e fazer tudo o que estiver ao nosso dispor, para realizarmos a ideia de uma comunidade ética. Só assim é possível esperarmos uma ajuda divina e nos livrarmos do mal que nos assedia. Só se fizermos o que devemos e podemos fazer, podemos ser merecedores da felicidade como dádiva divina e firmar nossa esperança de que o reino de Deus (sumo bem comunitário) virá a nós, vencendo o mal que nos assola. Os homens formam comunidades imperfeitas, porque não conseguem instaurar, por forças próprias, a igreja verdadeira na terra. A ideia de uma religião pura e racional nunca será plenamente alcançável, restando apenas que os homens façam o que está ao seu alcance para realizar a ideia de sumo bem comunitário. Não é permitido que o homemdeixe para outro o que ele mesmo deve fazer. Segundo Kant [1793] (2008): “Contudo não é permitido ao homem estar inativo (...) há de proceder como se tudo dele dependesse, e só sob esta condição pode esperar uma sabedoria superior que garantirá ao seu esforço bem intencionado a consumação (2008, p.107)". Entretanto, continua Kant [1793] (2008):

(...) um reino de virtude (do princípio bom), cuja ideia tem na razão humana a sua realidade objetiva inteiramente bem fundada (...) embora subjetivamente jamais se pudesse esperar da boa vontade dos homens que eles se decidiriam a trabalhar em concórdia em ordem a tal fim (2008, p.101).

Conforme está dito acima, a ideia de uma comunidade ética é objetivamente válida, já que na filosofia de Kant ela (ideia) promana da moral. Entretanto, a realização dessa ideia não pode ser esperada (do ponto de vista subjetivo) da boa vontade dos homens. Ainda assim, é necessário que façamos tudo o que pudermos para realizar a ideia. Os nossos esforços serão marcados por fracassos, mas é nosso dever tomar como máxima o dever de fomentar a comunidade ética no mundo. Parece paradoxal, mas é exatamente isso que está dito, a saber, que a ideia não pode ser realizada, mas nós devemos fazer tudo o que pudermos, sem contar com a boa vontade dos outros. Sabemos que apenas Deus pode realizar uma comunidade ética, por causa da própria exigência do conceito de sumo bem comunitário. Entretanto, é necessário agirmos como se pudéssemos realizar a ideia de uma igreja invisível. Com esse fazer, o homem erra e inverte o conceito de religião racional Segundo 
Herrero (1991): "(..) a forma e organização concretas dessa igreja é obra dos homens, pois a vontade divina é que nós mesmos realizemos a ideia de uma comunidade ética. Quando se trata da configuração da ideia no fenômeno não só a reprodução é deficiente, mas é preciso contar com o insucesso (p.102)".

Só restou a Kant comparar o seu conceito de religião pura com as instituições humanas. Por isso, uma religião nos limites da simples razão é a aplicação da ideia de uma religião racional às religiões concretas. O resultado disso é que não poderemos inserir uma religião nos limites da simples razão à ética pura, na medida em que uma religião nos limites da simples razão é o resultado da interação entre religião pura e religião fenomênica, obrigando a religião estatutária a ceder lugar para a verdadeira religião moral. Kant não pôde encontrar na história das religiões nenhuma que pudesse ser adequada plenamente à ideia de religião pura ${ }^{43}$ e, por isso, teve que se conformar apenas em aplicar o conceito de religião pura à religião estatutária, exigindo da última que as suas proposições de fé não entrem em desacordo com a moral, mas busquem, progressivamente, submeter suas práticas e doutrinas à ideia de uma igreja invisível, eliminando tudo o que é incompatível com a determinação da vontade livre do homem.

Enquanto religião moral pura não se diferencia da ética quanto à matéria, pois ambas tem a ver com deveres. A diferença é apenas formal, dado que, no conceito de religião pura, é adicionado o conceito de Deus apenas para exercer influência sobre a vontade humana no cumprimento do dever. Mas tanto a religião pura quanto a ética dizem o mesmo. Podemos dizer, com base nesse resultado, que a religião racional, na verdade, é uma continuação da ética e dela depende para ganhar subsistência. A submissão da religião estatutária à igreja invisível é também uma submissão da religião à moral, não só no próprio desenvolvimento do conceito de religião pura (que não se diferencia da moral), mas também da religião estatutária (baseada na revelação), que deve ser orientada desde o horizonte do conceito de religião pura.

43 Kant [1793] (2008) dá certo privilégio ao cristianismo por entender que há nas proposições de fé dessa religião uma maior convergência com o conceito de religião racional. Entretanto, isso não significa que Kant aceite o cristianismo tradicional, onde a revelação ou a tradição é o supremo fundamento da religião. Ele demarca a diferença do que é racional e o que deve ser rejeitado no cristianismo. Por exemplo, a figura do Cristo perde o seu significado histórico (tão caro aos cristãos católicos) e serve apenas no seu sentido espiritual, a saber, a ideia de uma humanidade agradável a Deus. 


\subsection{Superação da religião estatutária}

Como a história a priori do estabelecimento do sumo bem comunitário deverá receber o seu ponto final através de Deus, o homem pode apenas formar uma igreja visível limitada, mas que deverá ser objeto de interpretação a partir de uma religião racional. Os motivos em torno desse caminho posto por Kant [1793] (2008) são resultantes da incapacidade de se encontrar, na forma de uma igreja concreta, uma que coincida com a comunidade ética. As formas históricas da religião estão sempre em déficit na sua relação com a religião verdadeira. Mas isso não significa que não seja possível colhermos elementos úteis ao desenvolvimento moral da humanidade dentro de uma religião estatutária. Kant [1793] (2008) diz:

(...) visto que a revelação pode pelo menos compreender também em si a religião racional pura, ao passo que esta, ao invés, não pode conter o histórico da primeira, ser-me-á possível considerar aquela como uma esfera mais ampla da fé (...) $(2008$, p.21).

A necessidade de sensificar conceitos abstratos da razão fez com que o homem representasse o reino de Deus por meio de uma religião estatutária, possibilitando um meio pelo qual o entendimento humano pudesse entender os conceitos abstratos da moral. Tornar intuitiva a ideia de sumo bem comunitário, para que o entendimento humano possa acessar o conteúdo puro da religião por meio de símbolos é a finalidade pela qual o homem (por uma carência sensível) torna elementos abstratos intuíveis para sua própria compreensão. O elemento simbólico da religião estatutária deve ser remetido ao seu fundamento verdadeiro, que é a religião pura. Segundo Kant [1798] (2006):

Mas nas exposições dos conceitos (denominados ideias) pertinentes à moralidade, que constitui a essência de toda religião, e, portanto a razão pura, distinguir o simbólico do intelectual (o culto da religião), distinguir o invólucro, necessário e útil por algum tempo, da coisa mesma (...) (2006, p.90).

As idéias morais constituem a essência de toda a religião moral.Como foi mostrado que a religião estatutária deve se submeter à religi ão da razão, então os elementos simbólicos da religião estatutária devem ser remetidos para o 
elemento espiritual (moral) da religião. O conhecimento simbólico da religião, na medida em que serve a uma função determinada, a saber, tornar intuível os conceitos abstratos da razão, tem uma utilidade apenas temporária. Isso nos mostra também o interesse de Kant na moralização das igrejas visíveis. As proposições de fé enquanto são símbolos religiosos devem se remeter a ideias religiosas racionais. É necessário distinguir o invólucro (o símbolo) da coisa mesma (conceito puro de religião). O símbolo é "necessário e útil por algum tempo". Segundo Kant [1798] (2006): "As formas das coisas (intuições), conquanto se limitem a servir de meio à representação por conceitos, são símbolos, e o conhecimento por meio destes se chama simbólico ou figurado (speciosa) (Kant, 2006 [1798], p.89)”. O conhecimento simbólico é limitado, dado que ele se remete a outro: "conquanto se limitem a servir de meio à representação por conceitos". O problema é que as religiões estatutárias confundem o símbolo com a coisa mesma (conceito puro de religião). Kant alerta para o perigo de uma religião estatutária não conter nada de moral e ter apenas os estatutos e revelações como fonte da verdade religiosa.

Segundo Herrero (1991): "A religião pura é sempre a meta a alcançar, diante da qual a história deve finalmente desaparecer (p.184)". Desaparecimento da história aqui significa que a religião estatutária deve desaparecer (depois de cumprir sua missão moral), na medida em que faz tudo o que está a seu dispor para assumir os conceitos puros da razão, ao invés de se contentar apenas com um conhecimento figurado (simbólico). Enquanto figurado no campo religioso, o símbolo é sempre deficiente e não é adequado à forma perfeita dos conceitos puros da religião racional. Apenas se o símbolo ganha sentido por meio dos conceitos morais é que ele pode servir para tornar clara a função verdadeira a que foi incorporado às proposições de fé de uma religião estatutária. Segundo Kant [1793] (2008):

Por conseguinte, embora (de acordo com a limitação inevitável da razão humana) uma fé histórica afecte como meio condutor a religião pura, contudo, com a consciência de que é apenas um meio condutor, e se esta fé, enquanto fé eclesial, traz consigo um princípio de aproximação contínua à pura fé religiosa para, finalmente, poder prescindir desse meio condutor $(\ldots)(2008$, p.121).

Com base na citação podemos dizer: 1)religião racional é resultado da exigência da razão, de pressupor um ser superior, para realizar a ideia de uma comunidade ética; 2) A religião estatutária inverte a ordem entre religião e 
ética e assume os estatutos como revelações divinas; 3) Em função da limitação de uma igreja visível, é necessário que ela seja interpretada à luz da razão prática; 4) O resultado da interação hierárquica entre religião pura (que tem a primazia) e religião revelada (que é uma forma imperfeita da religião racional), é a exigência de que a religião estatutária seja substituída, paulatinamente, pela única religião verdadeira (a religião pura da razão). Portanto, a religião estatutária recebe em Kant apenas o papel de ser um veículo para a religião racional; 5) A religião revelada não é investigada, desse modo, em si mesma, mas perde-se na comparação entre ela e a exigência moral. Ela não é vista desde o seu próprio horizonte, mas apenas como um veículo da moral. Os cultos não possuem um sentido em si. Nada do culto pode agradar a Deus. Agradamos a Deus, segundo Kant, apenas quando cumprimos o dever moral. E como o cumprimento do dever moral depende de disposições moralmente convertidas (o que não pode ser encontrado na experiência), a verdadeira igreja é invisível, porque apenas Deus é o perscrutador dos corações. Segundo Kant [1793] (2008): "O homem comum entende sempre por religião a sua fé eclesial que se lhe apresenta aos sentidos, ao passo que a religião é interiormente oculta e depende de disposições de ânimos morais (Kant, 2008, p.114)".

$\mathrm{Na}$ história de realização do sumo bem comunitário, não foi possível encontrarmos tal ideia na experiência concreta (histórica). Foi encontrada a imperfeição das religiões históricas, o que fez com que Kant concebesse uma "religião nos limites da simples razão". A "religião nos limites da simples razão" conta com a história da religião enquanto fenômeno, e aceita que só é possível pensarmos a realização da ideia de sumo bem comunitário, se interpretarmos todos os conteúdos aceitos por uma igreja visível à luz da razão prática e tomarmos como máxima a lei moral que é a única fonte de acesso a Deus. Entretanto, por uma carência (de ter que ter um apelo sensível) dos símbolos para compreender a religião racional, erramos na meta posta pela religião racional e decaímos na religião estatutária. Não podemos confundir símbolos com a coisa mesma, nem deixarmos de distinguir a fé racional e a fé eclesial. A fé na representação simbólica precisa (desde a fé racional) ceder lugar à coisa mesma. O grande erro, segundo Kant, é confundir o símbolo religioso com a verdade religiosa. O símbolo quer apenas indicar um caminho. A religião racional enquanto é representada na religião 
estatutária precisa ser compreendida espiritualmente (moralmente). A mera representação obtém com isso uma utilidade. Se o símbolo não sofresse uma interpretação moral dos seus conteúdos perderia sua função. A representação fenomênica do conceito de religião é marcada por desvios. A fraqueza da natureza humana, no empreendimento moral de realizar uma comunidade ética, não alcança a ideia de religião racional. Ela precisa sensificar (tornar intuível) conteúdos racionais para acessar o sentido moral a priori da razão. Entretanto, nesse caminho orientado pela ideia de religião, o homem deixa de remeter o símbolo ao seu sentido moral e, tomado por uma fé eclesial, confunde a representação com a própria religião. Tornando a religião estatutária a religião verdadeira, o homem perde-se do sentido verdadeiro dos símbolos religiosos. Segundo Kant [1793] (2008):

A primeira presume tornar-se agradável a Deus mediante ações (do culto) que (embora trabalhosas) não têm por si qualquer valor moral, portanto, são ações extorquidas por temor ou esperança, ações que também um homem mau pode executar, ao passo que a segunda pressupõe para tal como necessária uma disposição de ânimo moralmente boa (p.121).

Podemos concluir o segundo capítulo com as seguintes afirmações: 1) A religião estatutária representa (ainda que imperfeitamente) a religião racional; 2) a religião estatutária nasce de uma fraqueza humana, a saber, de ter que acessar um elemento sensível para compreender ideias racionais; 3) Os símbolos religiosos precisam ser interpretados pelas ideias morais, ainda que (no caso de um livro sagrado) tenhamos que impor a eles um sentido moral;4) A religião nos limites da simples razão consiste na aplicação do conceito de religião racional à religião estatutária; 5) Importa que a religião seja apenas racional e, por isso, a religião estatutária deve rumar para desvencilhar-se de toda simbologia e ficar com a coisa mesma (religião pura da razão).

No próximo capítulo, mostraremos como a filosofia contemporânea seguiu um viés distinto do de Kant para a interpretação da religião e se aproximou mais da via proposta por Schleiermacher. O conceito puro de religião é substituído por uma investigação pautada na experiência religiosa. Mostraremos ainda que Kant continua exercendo sua influência no pensamento filosófico da religião contemporâneo, expondo as linhas gerais da atual hipótese pluralista de John Hick. 


\section{Capítulo 3 - O conceito racional, experiência religiosa e pluralidade das religiões}

Nos capítulos anteriores foi mostrado o conceito racional de religião e sua relação com a religião positiva no pensamento de Kant. Foi dito que o conceito de religião racional de Kant não comporta nada de sensível, a menos que o sensível esteja a serviço de tornar compreensível o conceito racional de religião. E uma religião nos limites da simples razão consiste na aplicação do conceito racional de religião à religião positiva, estabelecendo uma hierarquia entre elas, sendo que a religião positiva passa a ser vista como representação sensível da religião racional, sendo condenada ao desaparecimento por sua própria missão, a saber, promover o sumo bem comunitário no mundo. Dessa forma, a religião não tem uma esfera própria e depende da moral. Mostraremos que o viés kantiano de investigação da religião se esbarra em sua redução à moral

Exploraremos as considerações de Schleiermacher, que partindo da experiência religiosa, separa a religião da esfera da metafísica e da moral. Ao contrário de Kant, a religião positiva no pensamento de Schleiermacher não é reduzida à moral ou a especulação metafísica. Ela tem o seu próprio lugar, sua área determinada. Este viés que parte da experiência religiosa e não de um conceito a priori influenciará uma nova forma de abordar a religião. Forma esta que parte da experiência religiosa e não de um conceito natural de religião. Schleiermacher influencia toda uma geração de pensadores, passando por Kierkegaard (1843)(1979) com seu livro Temor e tremor, Rudolf Otto (1917)(1985) e seu livro O sagrado: um estudo do elemento não-racional na idéia do divino e a sua relação com o racional, William James(1902) com o livro The VarietiesofReligious Experience, MirceaEliade (1957)(1992) com o livro $O$ sagrado e o profano, chegando ao mundo contemporâneo com William Alston (1991) e seu livro PerceivingGod - The EpistemologyofReligious Experience e, especialmente, a atual hipótese pluralista de John Hick que será abordada neste capítulo.

Concluiremos este capítulo oferecendo elementos da contemporânea hipótese pluralista de John Hick para mostrarmos a influência, tanto da mudança de paradigma oferecida por Schleiermacher, quanto do pensamento 
de Kant, no debate atual sobre o pluralismo religioso. Hick parte da experiência religiosa, mas conserva a distinção kantiana entre númeno e fenômeno e a proposta de um critério geral de avaliação das religiões, além de mostrar os limites das faculdades cognitivas para conhecer o Real. Desse modo, será mostrado que apesar de reduzir a religião à moral, Kant não deixa de influenciar a filosofia da religião no mundo contemporâneo.

\subsection{Kant e a superioridade do cristianismo}

Nos capítulos anteriores, dissemos que o conceito de religião em Kant é racional e dado a priori como consequência necessária da moral. Por isso, a religião racional é anterior a todas as configurações religiosas e as submete de acordo com o critério da moralidade.

A religião racional deve ser realidade no fenômeno. Kant [1793] (2008) diz que: “A visível é a união efetiva dos homens num todo que concorda com aquele ideal (2008, p.107)". Entretanto, as tentativas do homem para formar uma comunidade ética malogram por causa de sua incapacidade de cumprir tudo o que é ordenado pela razão. Segundo Herrero (1991): “Quando se trata da configuração da ideia no fenômeno não só a reprodução é sempre deficiente, mas é preciso contar com o insucesso (1991, p.102)".

A religião não procede da revelação de uma comunidade histórica. É a razão que mostra a priori o dever que se chama "mandamento divino" na religião natural ou racional. Deus é um conceito prático (atende a fins morais) e não um conceito teórico. Por isso, a filosofia de Kant não se preocupa em provar ou deixar de provar a existência de Deus, mas conferir a este conceito um valor prático, que ajude o melhoramento moral dos homens. Religião é, portanto, um conceito que emerge da moral e não de uma revelação ou manifestação fenomênica da religião positiva. Por isso, Kant nos diz [1793] (2008): “Não se trata tanto de saber o que é Deus em si mesmo (a sua natureza), mas o que para nós é como ser moral (...) (2008, p.145)”.

A religião positiva é uma manifestação imperfeita da religião racional porque conceitos racionais puros (Ideias) não podem ser plenamente representados numa forma sensível. A forma sensível deve ser remetida à Ideia de religião racional. Quando uma forma de religião positiva toma o símbolo (fenômeno) como númeno (coisa em si mesma) ela se perde na letra 
morta e não mostra, por meio do sensível, o fundamento a partir do qual o sensível foi posto, a saber, tornar compreensível conceitos abstratos, que precisam de instrumentos para tornarem-se claros aos religiosos, e desta forma, tornar pública (comunicável) sua religião. Por isso, todo o esforço da religião positiva deve ser no sentido de trazer à luz os conceitos morais da religião racional, como uma "obra que lhes é confiada".

Kant [1793] (2008) o conceito de religião moral prioriza a moralidade das disposições e não os cultos ou qualquer outra forma exterior de manifestar a religião. Por isso, Kant diz que há uma só religião (religião racional), entretanto são diversas as formas pelas quais essa religião se manifesta. Cada uma dessas manifestações é uma forma de influenciar a vontade à ação moral. Por isso, a religião positiva é um meio e não um fim. A religião moral é o conceito geral de religião, enquanto a religião positiva se situa em um campo mais restrito, dado que ela é consequência da disposição humana à religião moral. Segundo Kant [1793] (2008):

(...) visto que a revelação pode pelo menos compreender também em si a religião racional pura, ao passo que esta, ao invés, não pode conter o histórico da primeira, ser-me-á possível considerar aquela como uma esfera mais ampla da fé, que encerra em si a última como uma esfera mais estreita (...) (2008, p.21).

Kant afirmou que as revelações podem, pelo menos, compreender uma parte reduzida da religião racional. O contrário não é verdadeiro, já que a religião moral tem origem na razão, independente da experiência das tradições religiosas. O que é assumido por Kant é que, por um impulso da disposição moral que ordena que formemos uma comunidade ética a fim de nos livrarmos dos ataques do mal, a religião positiva é uma resposta imperfeita a esta disposição à religião pura e racional. A igreja visível (qualquer que seja) é uma reprodução imperfeita da ideia da razão (igreja invisível). A religião positiva não pode comunicar a sua revelação de forma universal. Os conteúdos de uma revelação estão restritos ao tempo e ao lugar do seu nascimento (onde tudo é contingente) e, por isso, não podem comunicar racionalmente (universalmente) o conteúdo de sua fé. Somente se uma religião positiva estiver com o fito de remeter todos os seus símbolos ao sentido moral é que ela poderá encontrar o que há de verdadeiro na sua constituição, a saber, o comando da razão que ordena a formação de uma 
comunidade, onde homens e mulheres possam se desenvolver moralmente.

Por isso, a revelação deve ser interpretada à luz da religião racional ${ }^{44}$. Segundo Kant [1793] (2008):

Que isto, porém, se possa fazer sem faltar sempre muito ao sentido literal da crença popular deve-se a que, muito antes desta, estava oculta na razão humana a disposição para a religião moral, disposição cujas primeiras manifestações rudes se encaminhavam apenas para o uso do culto divino e, para tal fim, ocasionaram aquelas pretensas revelações, mas puseram outrossim nestes poemas - embora não de propósito - algo do carácter da sua origem suprassensível. Não se pode acusar de deslealdade a semelhantes interpretações, no pressuposto de que não se pretende afirmar que o sentido, por nós dado aos símbolos da crença popular ou também aos livros sagrados, tenha por eles também sido absolutamente intentado, pois isso fica por decidir e apenas se aceita a possibilidade de assim compreender os seus autores. Pois até a leitura dos livros sagrados ou a inquirição do seu conteúdo tem como intuito final tornar os homens melhores; mas o histórico, que em nada contribui para tal, é algo em si totalmente indiferente, com o qual se pode lidar como se quiser (grifo meu) (2008, p.117).

Não é necessariamente obrigatório que tenhamos que interpretar um texto sagrado e lhe conferir um sentido em si mesmo. Os símbolos revelados têm a finalidade de mostrar no fenômeno a Ideia de religião, não para ficarem em si mesmos, isto é, fechados em um significado restrito ao tempo e ao lugar de uma determinada religião positiva. A religião cristã deve ser interpretada à luz da religião racional, assim como todas as outras tradições religiosas. Segundo Kant, há interpretações morais dadas a conteúdos revelados que, se permanecessem fiéis à literalidade de seus mitos, malograriam em sua função de tornar os homens melhores. Por isso, Kant [1793] (2008) diz: "O judaísmo tardio e, inclusive, o cristianismo constam de tais interpretações, em parte muito forçadas, mas em ambos os casos para fins indubitavelmente bons e necessários para todos os homens (2008, p.118)". Como toda manifestação da disposição à religião racional se encaminha para o sentido moral, então é necessário conceder um sentido moral a todas as revelações, não nos sendo

44Segundo Kant [1793] (2008): “Assim aconteceu com a doutrina de S. Paulo sobre a predestinação, a partir da qual se torna evidentíssimo que a sua opinião pessoal deve ter sido a predestinação no sentido mais estrito da palavra, doutrina que, por isso, foi também aceite na sua fé por uma grande Igreja protestante; porém, subsequentemente, foi de novo abandonada por uma grande parte desta Igreja ou, então, interpretou-se de outra maneira o melhor que foi possível, porque a razão a acha incompatível com a doutrina da liberdade, a imputação das acções e, por isso, com toda a moral (p.56)". 
permitido acusar de deslealdade um intérprete que estabeleceu sentido diferente do literal às revelações que, se deixadas a si mesmas, nada teriam a dizer sobre como tornar o homem melhor.

A expressão de Kant que diz "mas o histórico, que em nada contribui para tal, é algo em si de totalmente indiferente, com o qual se pode lidar como se quiser", não quer dizer que podemos conceder todo e qualquer sentido arbitrário à religião positiva. O critério estabelecido pelo conceito de religião racional é que a religião positiva deve promover a melhora moral dos homens. Com esse critério, Kant submete toda forma de religião positiva a uma só religião, a saber, a religião da razão. Entretanto, segundo Kant [1793] (2008): "(...) no esforço do homem em vista de uma comunidade ética, a fé eclesial precede naturalmente a fé religiosa pura (2008, p.110)". Mas isso não significa que a fé histórica ou eclesial numa revelação contenha em si o que é religião. Só na medida em que essa determinada forma de religião positiva tende ao seu verdadeiro sentido (melhoramento moral dos homens) ela deixa de ser morta e passa a conter o espírito de virtude que é necessário à letra de uma religião (a escritura, os dogmas, rituais e tudo de histórico).

A Ideia de religião (religião racional) é em si mesma válida absolutamente, dado que a sua forma pode ser comunicada universalmente. Como a razão é prática em si mesma (porque pode fornecer uma lei a priori que determina a vontade às ações), e como todo homem é racional, então o conteúdo da religião racional é o único que pode ser comunicado universalmente, ao contrário da religião revelada ou positiva que depende de uma revelação. Uma revelação acontece a um povo e a uma religião, ao passo que a religião racional está como que gravada em nossos corações ${ }^{45}$. Kant [1793] (2008) preocupou-se em dizer que uma mensagem religiosa só pode ser comunicada a todos os homens quando o que se comunica são conceitos morais. Segundo Kant [1793] (2008) Não há como reivindicarmos superioridade sobre outros credos de fé e povos, a menos que a nossa mensagem possa ser comunicada a cada homem, independente de sua cultura. Por isso, no sentido em que Kant

45Kant [1793] (2008), diz que: "Mas, embora se aceitem também leis divinas estatutárias (que se deixam reconhecer como tais não por si mesmas enquanto obrigatórias, mas só enquanto vontade divina revelada), contudo, a legislação moral pura, graças à qual a vontade divina está originariamente escrita no nosso coração, não é só a condição iniludível de toda a verdadeira religião em geral, mas é igualmente o que em rigor constitui esta mesma, e em vista do que a lei estatutária unicamente pode conter o meio do seu fomento e extensão (2008, p.110)". 
[1798] (2008) compreende, só pode haver uma religião, ainda que haja diversos credos de fé:

Por isso, é também uma só e não há diferentes religiões, mas diversos tipos de fé na revelação divina e as suas doutrinas estatutárias que não podem derivar da razão, distintas formas de representação sensível da vontade divina para a esta propiciar influência sobre os ânimos, formas entre as quais o Cristianismo é, tanto quanto sabemos, a mais conveniente (grifo meu) (2008, p.55).

No primeiro momento de nossa reflexão parece que Kant nos forneceu um conceito de religião que abarque todas as formas positivas de religião. Com isso, nos parece ainda que essa garantia é também a garantia da igualdade dos diversos credos das religiões positivas. Por isso Kant afirma [1793] (2008): “(...) com a diversidade de modos de fé estatutários, pode instituir-se uma tolerância recíproca dos seus adeptos graças aos princípios da religião racional única (...) (2008, p.29)”. Entretanto, não é assim que podemos concluir os resultados da relação entre conceito racional/moral e as religiões positivas. A tolerância que Kant afirma brotar do conceito de religião racional privilegia o cristianismo. Na citação acima vemos Kant dizer que as religiões positivas são: “(...) distintas formas de representação sensível da vontade divina para a esta propiciar influência sobre os ânimos, formas entre as quais o Cristianismo é, tanto quanto sabemos, a mais conveniente (2008, p.55)".

Em primeiro lugar, a religião positiva é reduzida à moral e reduzida também a uma religião natural (religião racional que promana da moral). Com isso, temos a afirmação que de que todas as formas de religião positiva são formas imperfeitas de manifestar a Ideia de religião, já que tendem a ela. Kant ainda diz que as religiões positivas precisam assumir a fé moral como fator principal e, depois disso, substituir paulatinamente a religião revelada pela religião da razão. Podemos concluir que Kant tem uma relação negativa com a religião positiva, mas até aqui diríamos que essa relação negativa deveria ser estendida a todas as religiões.

Em segundo lugar, Kant assume que a história da religião se inicia apenas com o cristianismo porque este assume publicamente a moralidade das disposições como fito de todas as práticas externas da religião positiva. A perspectiva kantiana prioriza a ação moral e rejeita uma forma apenas externa de religião. Não basta irmos à igreja ou participarmos da comunhão, se o 
coração não for transformado, se o homem não tomar como máxima fundamental de suas ações o dever de melhorar moralmente cada vez mais, não adiantando, portanto, os cultos ou práticas de oração, as oblações, as rezas ou qualquer outra prática "religiosa". Nesse sentido, por causa da máxima moral que orienta o cristianismo, ela é a única religião positiva que é chamada de "religião verdadeira". Por isso, segundo Herrero (1991): "Não podemos começar essa história a não ser a partir das origens do cristianismo, o qual abandonou o judaísmo e lhe deu nascimento, e provocou uma revolução na doutrina da fé (1991, p.183)”.

\subsection{Schleiermacher e a especificidade da religião}

Os escritos do filósofo Schleiermacher Sobre a Religião: discursos aos seus menosprezadores eruditos [1799] (2000) ${ }^{46}$ visam estabelecer a essência de toda e qualquer experiência da religião. Schleiermacher [1799] (2000) procura um modo distinto de Kant para entender o fenômeno religioso. Não se procura mais um a priori racional para a religião. Procura-se o nexo entre finito e infinito na essência mesma da experiência religiosa, a saber, na intuição do infinito. Será mostrado que partindo da experiência da religião Schleiermacher concede um valor positivo à religião revelada. A pergunta fundamental é a seguinte: como se dá originariamente a essência da religião? Precisaremos abordar a religião na sua especificidade, distinguindo-a da metafísica e da moral.

A moral tem a ver com deveres e a metafísica com o conhecimento do Universo. Tanto a moral e a metafísica, quanto a religião, estabelecem relações entre o homem e o universo ${ }^{47}$. Entretanto, o erro para Schleiermacher é confundir a via de acesso à moral com a via de acesso à religião, ou a via de acesso à metafísica (conhecimento teórico) com a via de acesso à religião. A religião exige uma via de acesso diferente, sem que objetos estranhos a obscureçam. Segundo Schleiermacher [1799] (2000): “(..) muito do que pertence à religião se tenha ocultado, sob uma forma inapropriada, na

46 A partir de agora usaremos a abreviatura Sobre a Religião para nos referirmos ao presente livro.

47Segundo Schleiermacher [1799] (2000): "Situai-vos no ponto de vista mais elevado da metafísica e da moral; constatareis que ambas possuem o mesmo objeto que a religião, a saber, o Universo e a relação do homem com ele (p.29)". 
metafísica e na moral (p.29)". Ele quer ver a religião nela mesma, sem mediação da moral ou da metafísica. Kant, ao contrário, só consegue ver a religião desde à moral. Ainda Schleiermacher [1799] (2000): "E que tarefa desempenha a moral? Ela desenvolve a partir da natureza do homem e de sua relação com o universo um sistema de deveres. Ela prescreve e proíbe ações com um poder ilimitado (2000. p.29-30)". A moral é um dever ${ }^{48}$ para a vontade e tem a ver com ações. Quando Kant deduz o seu conceito de religião da moral, ele está renunciando à particularidade da religião e dando primazia à moral. Kant não alcança o religioso em si mesmo, na medida em que o religioso tem uma esfera própria que estabelece uma relação do homem com o universo, que se distingue de outros modos possíveis. Segundo o conselho de Schleiermacher [1799] (2000), referindo-se à necessidade de um olhar concentrado para o fenômeno religioso: “(...) sem distrair-se com objetos estranhos, concentre plenamente seu olhar em que o fenômeno deve se mostrar (2000, p.27)". Qual é a via de acesso à essência da religião para Schleiermacher? É uma intuição do universo que caracteriza a experiência religiosa.

Segundo Schleiermacher [1799] (2000): “Todo intuir parte de influxo do intuído sobre o que se intui de uma ação originária e independente do primeiro (...) (2008, p.36)". A intuição (realizada pelo sujeito) pressupõe um intuído (objeto). Sem a coisa que se intui não se pode intuir. Schleiermacher está falando de uma intuição como resultado de uma ação originária do intuído sobre o homem. Segundo Oliveira (2011):

Este influxo é originário e independente do sujeito que intui. Sendo assim, é impossível ter controle sobre esta experiência, uma vez que ocorre independentemente do sujeito. Ora, a intuição só é possível porque o Universo já se manifestou de antemão e por si mesmo. (2011, p.149).

Segundo a teoria kantiana, nós só podemos conhecer um objeto depois que o intuirmos. A faculdade que nos possibilita a intuição é a sensibilidade ${ }^{49}$ (não

48 Por isso, segundo Schleiermacher [1799] (2000): "(..) a religião tão pouco tem de intentar isso; não deve servir-se do universo para deduzir deveres, ela não deve conter nenhum código de leis (p.30)".

49Segundo Kant (1999): A capacidade (receptividade) de obter representações mediante o modo como somos afetados por objetos denomina-se sensibilidade. Portanto, pela sensibilidade nos são dados objetos e apenas ela nos fornece intuições; pelo entendimento, 
o entendimento como capacidade de fornecer conceitos) como capacidade de ser afetado pelo externo. Os dados dispersos da experiência, sem nenhuma arrumação conceitual, são recebidos no tempo e no espaço, por uma intuição pura (antes de ser preenchida por uma sensação). A intuição é uma representação particular que em si mesma não está referida ao conhecimento ou qualquer outra atividade racional (como a moral). Segundo Kant, não podemos conhecer um objeto apenas porque o intuímos. A intuição é uma atividade no tempo e no espaço e se transforma em matéria para o conhecimento, só depois que a reunimos, através das categorias do entendimento. Intuir é uma atividade passiva. Os objetos nos afetam, sem que tenhamos condições de decidirmos a respeito disso. O interessante para Schleiermacher é o caráter passivo da intuição, mas enquanto Kant coloca a intuição no âmbito de objetos particulares. Para Schleiermacher [1799] quando intuímos sofremos o influxo daquilo que se intui. Na essência da religião, segundo ele, sofremos a ação do Universo sobre nós e não de um dado particular. A nossa atividade é passiva nessa relação. Não há como deixarmos de receber o influxo do Universo, dado que não temos a capacidade de impedi-lo. O religioso é aquele que se abre a essa ação do Universo e faz dessa intuição fundamental o lugar a partir do qual tudo o que é finito entre em unidade com o Infinito. O homem enquanto finito intui a sua origem dentro e no Universo. Schleiermacher parte da intuição e não da reflexão racional para adentrar na essência da religião. Schleiermacher [1799] (2000) referindo-se à religião diz: “Tudo deve partir da intuição, e quem não anseia intuir o Infinito, não possui nenhuma pedra de toque, e tão pouco necessita de alguma, para saber se tem pensado algo apropriado acerca desse assunto (2000, p.35)". A religião é intuição do infinito. Na religião não se trata de intuir a natureza objetiva dos entes condicionados, mas o Universo. Segundo Oliveira (2011): “Não obstante, a intuição e o sentimento não têm origem numa relação com a natureza objetiva, mas com o Universo, que absolutamente não é um objeto presente na totalidade das coisas condicionadas (2011, p.146)". Sem intuição do Infinito, não podemos encontrar a "pedra de toque” da religião. Quando intuímos um dado sensível

em vez, os objetos são pensados e dele se originam conceitos. Schleiermacher [1799] (2000) quer encontrar a essência da religião numa intuição do Universo e não em um conceito abstrato do entendimento. 
objetivo, entramos em relação com um ente sensível e condicionado. Quando intuímos o Universo, temos um sentido que ultrapassa o mero apreender de um ente da natureza objetiva e entramos em relação com o incondicionado, sem que estejamos separados (numa relação de sujeito com o seu objeto) daquilo que se intui.

Kant, ao contrário, coloca o sujeito no centro do seu conceito de religião. É que na moral o homem é que deve agir como base na razão. Quando Kant alcança o seu conceito de religião, precisa colocar o sujeito como centro, assim como fez em sua filosofia moral, onde o sujeito é livre do influxo da natureza e que, por isso, é capaz de agir sem que seja determinado pelas leis da natureza. Mas a religião, para Schleiermacher, não é pensamento (teoria) ou moral (ação), mas intuição do Infinito (Universo). Segundo ele [1799] (2000), referindo-se à religião: "Sua essência não é pensamento e ações, quer ser impressionada, senão intuição e sentimento (2000, p.33)". O intuído na religião (Universo) é que se revela ao religioso. Aqui o homem não é o centro e sim o Universo. É a contemplação ${ }^{50}$ e não a ação moral que é centro da experiência da religião. Essa intuição independe do sujeito. Ele é o receptáculo e não agente central da experiência religiosa (intuição do Universo). Intuímos porque o intuído nos ativa. Isso significa afirmar que o homem encontra-se numa passividade ou receptividade originárias diante da ação do Universo sobre ele na essência da religião.

Destarte, não é suficiente compreendermos o que devemos fazer (moral), pois a religião tem a sua própria especifidade. O que devemos fazer, a moral nos diz. A religião é uma experiência humana que reúne o homem e o Infinito (Universo), reabilitando a unidade originária do homem com o mundo, através de uma intuição do Universo, por isso, é pressuposto que o Universo inicia tal relação. Na intuição o homem é o agente passivo e não ativo como no agir moral. A intuição, na religião, é de ordem especial, pois se trata de intuir o Universo e não um ente ordinário. Por isso, não nos é possível abarcarmos o Universo em si mesmo. O Universo é o Infinito e não poderíamos abarcá-lo em sua totalidade ${ }^{51}$, já que somos finitos. O que a religião produz é a

50Segundo Schleiermacher [1799] (2000): "Ela quer intuir o Universo, quer observá-lo piedosamente em suas próprias manifestações e ações, quer ser impressionada e plenificada, na passividade infantil, por seus influxos imediatos (2000, p.33)".

51Para Schleiermacher [1799] (2000): "(..) para mim a Divindade não pode ser outra coisa que uma forma particular de intuição religiosa (p.72)". Não há como, para Schleiermacher, 
compreensão de que estamos unidos com o Infinito e que, por isso, adentramos em nossa própria finitude. Nesse sentido, colocar a essência da religião numa intuição significa que, por um lado, valoriza-se o particular, por outro, o universal (o todo), sem que seja necessária uma separação do finito com o seu fundamento, a saber, o Universo infinito. Segundo Schleiermacher [1799] (2000): “Todo finito só se mantém mediante a determinação de seus limites, que por assim dizê-lo, têm de ser recortados do Infinito $(2000$, p.35)".

A experiência religiosa é pré-reflexiva e imediata. Retornarmos ao lugar próprio da religião significa acessar a sua especificidade. Não devemos confundir atividades abstratas (como a teologia moral e a metafísica) com a religião. A religião é um pôr-se em harmonia com o Infinito e remete toda a existência para esta experiência originária. Nessa experiência somos um com o Infinito. Ainda que sejamos finitos, só o somos desde o Infinito. Segundo Oliveira (2011):

Por isso, segundo Schleiermacher, a essência da religião encontra-se numa atividade pré-científica, pertence à esfera da intuição e do sentimento, sendo este o único modo de acesso imediato ao Universum. Isso significa dizer que as tentativas de racionalizar a religião descaracterizam o que é mais próprio desta, uma vez que sua fonte e origem pertencem a uma relação existencial imediata. A metafísica e a moral possuem um acento marcadamente científico, mediado sempre por conceitos e representações. No entanto, a religião antecede uma atitude científica, é um tipo de experiência que possui primazia em relação ao âmbito cognitivo da reflexão e da representação, constitui o antes de toda atividade teórica e de toda ação moral. Isto não quer dizer, porém, que tais tarefas de abstração e teorização não possam fazer parte da religião (2011, p.144-145).

A religião antecede qualquer atividade reflexiva. A relação entre o homem e o Universo na religião se dá de forma imediata, não reflexiva ou mediada pelos conceitos. As tentativas de racionalizar a religião estão fadadas ao fracasso, exatamente porque os processos de racionalização ou de reflexão acontecem posteriormente à experiência religiosa e limitam o seu alcance, confundindo a experiência em si com o que foi dito dela posteriormente. A

intuirmos o Universo enquanto tal na totalidade. Schleiermacher concorda com Kant que nossas faculdades cognitivas não podem abarcar o incondicionado em si. O que podemos receber é uma forma particular de configurar o influxo do Universo sobre nós. 
intuição do Universo tem a ver com nossa faculdade de recepção e não com nossa atividade racional. A religião vê apenas o infinito no finito. Entretanto, o finito não pode abarcar tudo o que essa experiência fornece. Conforme a citação "Isto não quer dizer, porém, que tais tarefas de abstração e teorização não possam fazer parte da religião". Não é negado por Schleiermacher [1799] (2000), que tais atividades marcadas pela reflexão e representação (moral e metafísica) possam fazer parte da religião. O que não é aceito é que a reflexão substitua a experiência pré-reflexiva e imediata da religião e coloque no seu lugar dogmas morais e metafísicos. O dogma religioso (mediação) não pode substituir a ação originária do Universo (imediata) sobre o homem. Tanto a moral quanto a metafísica são atividades racionais e “(..) a religião é sentido e gosto pelo infinito [1799] (2000) (p.35)".

A religião é o gosto pelo infinito porque ela coloca o homem numa relação de unidade com o Universo, cujos limites escapam ao entendimento humano. Nossos conceitos não podem abarcar o Universo em sua totalidade, mas a experiência religiosa coloca o homem dentro desse todo e estabelece uma nova relação do homem com o Infinito que se abre às possibilidades infinitas. A religião constitui o antes de toda a atividade moral ou teórica e se baseia numa intuição do Universo. Segundo Schleiermacher [1799] (2000): “A intuição é e permanece sempre algo particular, separado, a percepção imediata, nada mais; uni-la e juntá-la em um todo já não é o dever do sentido, antes do pensamento abstrato (2000, p.37)". Os dogmas e narrativas sobre tal experiência não são fundamento da experiência religiosa e sim posteriores ao fenômeno. O homem sofre a atividade ${ }^{52}$ do Universo. Logo que o homem interpreta essa atividade o Universo escapa às suas conclusões . Aparentemente seria contraditório para Schleiermacher [1799] (2000) erguermos uma religião (sob o pressuposto de superioridade) em detrimento de outras. Segundo Schleiermacher, referindo-se às religiões positivas [1799] (2000): “Todos devem ser conscientes de que a sua [religião] constitui tão só uma parte, de que, acerca dos mesmos objetos que lhes afetam religiosamente, existem pontos de vista que são tão piedosos e, todavia são totalmente distintos dos seus (...) (2000, p.40)". 
O problema consiste em acharmos que a nossa forma de expressar a religião seja reduzida a nossa limitação histórica, tomando assim a nossa intuição particular de religião como a "verdadeira". Como o "intuir" pressupõe uma atividade independente do homem, para Schleiermacher, cada coisa particular deve ser entendida como obra do Universo. A atividade do Universo sobre os homens produz diversas formas de intuição que, por sua vez, produz diversas formas de religiões. O elemento interno consiste em sermos impressionados pelo Universo ao intuirmos o seu influxo sobre nós. Nessa experiência, o homem ainda não está separado do Infinito. Aqui não há sujeito e objeto. A intuição do Universo nos abre um caminho de compreensão sobre ele, mas a partir de uma particularidade reconciliada com a universalidade (Infinito) e não da universalidade de um conceito abstrato. Entretanto, como somos finitos, o que podemos dizer a respeito de tal experiência sempre escapa à linguagem. Por isso, segundo Schleiermacher [1799] (2000): "Dado que toda comunicação da religião não pode ser senão de caráter retórico (...) (2000, p.33)". Como base nessa constatação, não nos deveria ser permitido julgarmos como ilegítimas as instituições religiosas de outras culturas.

Neste instante, no momento em que o influxo do Universo toca o homem e um novo modo de compreender se abre, tudo que é finito no mundo é remetido ao todo (Infinito). As partes que constituem o real são vistas desde o seu substrato originário (o Todo). Segundo Schleiermacher [1799] (2000): “(..) a visão religiosa propriamente dita de todas as coisas, até no que nos parece mais comum e baixo, consiste em rastrear toda a impressão do Divino (...) (2000, p.138)". O homem religioso coloca o mundo na perspectiva do Infinito, entretanto, isso não deve significar que há apenas uma perspectiva do Infinito. Ao contrário, nos foi mostrado que a intuição se refere sempre ao particular e não ao geral. Em cada intuição, o sujeito é agente passivo. Na religião, ele recebe a atividade do Universo e a intui. Enquanto intuição, o homem a exprime de modo particular. Cada ação do Universo tem a peculiaridade de ser uma intuição particular no homem e, portanto, um modo de ver particular e não abstrato ou geral. Por isso, existe uma diversidade de credos religiosos. Esses todos são legítimos, dado que são respostas ao influxo do Universo sobre o homem que o intui. Segundo Schleiermacher [1799] (2000): “Toda força infinita, uma vez que se divide e se separa em suas manifestações, se revela também através de formas peculiares e 
diferentes (2000, p.138)". Schleiermacher [1799] (2000) ainda continua: "Tenho dado por assentado, por onde quer que for, a multiplicidade das religiões e sua diversidade mais determinada como algo necessário e inevitável (2000, p.137)”. Schleiermacher [1799] (2000) endossa:

\begin{abstract}
Se se exige que uma religião determinada não comece por um fato, ela não poderá começar de modo algum: pois é preciso que haja ai um fundamento subjetivo, do por que algo sai à luz e é posto no centro; e, se uma religião não tem de ser uma determinada, não é religião alguma, senão uma matéria inconsistente, desconexa (2000, p.157-158).
\end{abstract}

O Infinito se manifesta no finito (fundamento subjetivo), e como expressão dessa manifestação, a religião positiva se estabelece enquanto tal (determinação do fundamento subjetivo). A religião tem, portanto, duas faces de uma mesma moeda. Uma subjetiva e uma objetiva. A religião é originariamente subjetiva, porque o Universo entra em relação profunda (interior) com o finito. E é objetiva se compreendermos que a religião positiva seria uma resposta legítima a este influxo do Universo sobre o finito. Esta resposta é sempre dependente da cultura de cada época. A interação entre o Infinito e Finito resulta numa intuição particular que se exprime através de uma forma concreta e também particular de religião. Por isso, segundo Schleiermacher [1799] (2000): “Ambos os fatos são efeitos de um só e mesmo momento, e, portanto, um não pode separar-se do outro (2000, p.154)”. O valor que Schleiermacher dá a religião insiste que a religião só ganha determinação a partir de sua expressão institucional ou estatutária (religião positiva) e que, por isso, todas as formas de religião positiva são legítimas respostas do homem à ação do Universo. A experiência humana que não se externalizasse em uma religião positiva não seria uma experiência religiosa. Por isso Schleiermacher [1799] (2000) diz: “(...) tão pouco um homem religioso pode alcançar sua individualidade, sem inserir-se também mediante a ação em alguma forma de determinada de religião (p.154)". Ao contrário de Kant, que legou à religião estatutária um valor reduzido, priorizando a religião natural (racional), Schleiermacher afirma que as diferentes formas de religião, são diferentes formas de intuir o Universo. Se o Infinito se manifesta no finito, o resultado desta interação traz a marca do finito. Segundo Schleiermacher [1799] (2000): 
(...) considerai também a embalagem que o divino teve que se revestir; não esqueçais também que ela leva em si por onde for as impressões da cultura de cada época, da história de cada raça humana, que ela amiúde teve que assumir a figura de servo, manifestando em seu meio ambiente a indigência de seus discípulos (...) (2000, p.159).

De acordo com a citação acima, nós devemos considerar também “ $a$ embalagem que o divino teve que se revestir". Na essência da religião há uma ação do Universo sobre o finito (homem). Nesse influxo o Infinito se reveste dos limites do finito. A "embalagem" é o revestimento cultural sob o qual se insere a religião de cada povo e em cada época. Não há como conhecer o Infinito em sua totalidade, nós apenas podemos ser tocados pelo poder do Infinito. Enquanto limitada à época e à cultura, a religião positiva expressa, de acordo com essa mesma cultura, a intuição do Infinito ou do divino, a partir da experiência religiosa. Como cada cultura varia de uma para a outra, a religião positiva variará de uma para a outra. Nesse momento de unidade entre experiência religiosa (fundamento subjetivo) e determinação da experiência religiosa (religião positiva), o divino (Infinito) manifesta em seu "meio ambiente" os limites do finito ou a "indigência de seus discípulos", levando em si as "expressões da cultura de cada época" e da "história".

Cada forma determinada de religião é um espaço a partir do qual o Infinito se manifesta. Dentro do Universo o mundo se movimenta e aparece. Cada religião positiva é verdadeira somente porque emana do Eterno (Infinito). Enquanto parte, a religião positiva se insere em um campo maior (Todo). Sem exceção, todas as religiões são expressões do influxo do Universo sobre o finito. Segundo Schleiermacher [1799] (2000): “Só no conjunto de todas as formas, concebidas como possíveis segundo esse enfoque pode manifestar-se realmente a religião em sua totalidade (...) (2000, p.148)". O “conjunto de todas as formas" são as religiões positivas.

Schleiermacher nos deu condições de vermos a religião positiva de forma diferente da que Kant nos fez. Kant fica com o conceito de religião racional (moral) e dispensa as formas de religião estatutária ou positiva. Existe um valor relativo dado à religião estatutária que é reduzido à moral. A função da religião positiva é promover a religião a priori da razão (religião moral). Como no conceito de religião racional não há nenhuma mistura de elementos empíricos, então todas as formas históricas de religião devem ser substituídas 
pela religião da razão (religião moral).

Parece que conseguimos uma forma de compreender a religião de uma forma que garante isonomia entre os diversos credos religiosos. Segundo Schleiermacher [1799] (2000): "(..) esta amistosa e acolhedora tolerância surge de uma forma imediata do conceito de religião (...) (2000, p.40)"; e quase temos a garantia de que encontramos o caminho para o diálogo isonômico entre as religiões quando esbarramos da seguinte constatação de Schleiermacher [1799] (2000): “Tenho pressuposto assim, a pluralidade das religiões, e assim mesmo a encontro fundamentada na essência da religião (grifo meu) (2000, p.137)". Entretanto, as conclusões de Schleiermacher sobre essa questão nos fazem indagar sobre tal pluralismo, quando ele olha parcialmente para o cristianismo. Vejamos o que ele diz:

Este fato, a saber, que o cristianismo em sua intuição fundamental mais peculiar contemple, sobretudo e de forma preferencial, o universo no marco da religião e de sua história, que ele elabore a própria religião como matéria para a religião, sendo deste modo, por assim dizê-lo, a religião em uma potência superior (...) (2000, p.166).

Se o cristianismo é privilegiado como religião positiva, então estamos diante do mesmo problema que nos foi posto por Kant. No cristianismo, segundo Schleiermacher a intuição do Infinito alcança a sua forma mais apropriada. Nisso consiste o limite das outras religiões positivas: em não ter colocado como tema principal de sua mensagem o tema da reconciliação entre finito e Infinito. Entretanto, cada religião parte de uma intuição do Infinito que em si é eterna, dado que cada uma delas é uma parte desse Todo (Universo) e no qual tudo deve ser igualmente eterno, mas, as formações particulares de uma religião positiva quase sempre colocam no centro de sua religião um objeto distinto do que aquele que propõe a religião, a saber, a reconciliação entre o finito e o Infinito na essência mesma da religião. Como em Kant, Schleiermacher não quer encerrar a religião em geral numa forma particular de religião positiva, mas acredita que as diversas formas determinadas de religião positiva compõem o Todo do qual elas são parte. Entretanto, acredita que o cristianismo é a forma de religião positiva que coloca a própria religião (reconciliação entre Deus e o homem)como objeto de sua doutrina. A doutrina da mediação de Cristo nos revela que a doutrina cristã tem como meta a reconciliação do homem com Deus, a inserção do 
homem no Todo e no Infinito, ou seja, a religião é objeto central do cristianismo. Por isso Schleiermacher [1799] (2000) chama a religião cristã de "Religião das religiões (...) (2000, p.175)".

Kant afirmava que o conceito de religião racional somente se refere ao de religião positiva ou estatutária caso ela seja capaz de conduzir o crente à sua própria razão. Schleiermacher [1799] (2000) teve uma vantagem sobre Kant que consiste em ter percebido que a experiência religiosa não pode subsistir sem uma forma determinada de religião positiva. Uma intuição do Infinito no infinito (experiência religiosa) resulta sempre numa determinada forma de religião positiva. Entretanto, Schleiermacher [1799] colocou o cristianismo numa posição de superioridade, na sua comparação com outras tradições religiosas. Mas esta prioridade que o cristianismo recebe de Kant e Schleiermacher, não será prejudicial na promoção do diálogo democrático no atual quadro plural de credos de fé convivendo num mesmo es paço social?

A mudança de paradigma que foi efetuada por Schleiermacher consiste em ter partido da experiência religiosa e ter concedido a partir disso um valor mais amplo à religião positiva. Kant, apesar de ter conferido um valor pedagógico à religião positiva privilegiou a religião racional, submetendo a religião positiva à moral. Schleiermacher [1799] partiu da própria religião, impedindo um reducionismo da religião à moral ou a qualquer outra forma distinta dela mesma.

No próximo item mostraremos que o pensamento contemporâneo de John Hick sofre influência, tanto da mudança de paradigma efetuada por Schleiermacher, quanto da filosofia de Kant.

\subsection{John Hick e o Pluralismo Religioso}

Uma das maiores preocupações do filósofo e teólogo contemporâneo John Hick é mostrar que a pressuposição de superioridade cristã foi sumamente prejudicial para o estabelecimento de um diálogo democrático com outras grandes tradições religiosas ${ }^{53}$. Além disso, o cristianismo, sob a pretensão de

53 John Hick parte apenas das grandes religiões pós-axiais, a saber, o budismo, o cristianismo, o judaísmo, o islamismo e o hinduísmo e suas vertentes. Ele afirma: "Com a expressão "crenças" ou "diferentes religiões" da nossa tenho e terei em mente principalmente as outras 'grandes religiões mundiais', especificamente o judaísmo, o islamismo, o hinduísmo e o budismo (2000, p.34)". 
ser superior, compreende as outras tradições religiosas como tradições falsas. A pressuposição de que o cristianismo foi fundado pelo próprio Deus (Jesus Cristo compreendido como Deus encarnado ou segunda pessoa da trindade), deu azes à ideia de que há somente uma religião verdadeira, e que essa religião é o cristianismo. Para superar essa ideia, John Hick parte do princípio de que as religiões são resultado de uma mesma experiência com o Real. Entretanto, como cada comunidade religiosa está situada em uma cultura específica, cada uma delas compreenderá o Real de acordo com o seu próprio esquema conceitual que foi construído em sua própria comunidade. Dessa forma, nenhuma das religiões pode julgar-se superior à outra.

Entre os fatores que contribuíram para o desgaste da tese exclusivista ${ }^{54}$ (segundo a qual o cristianismo é o único caminho de salvação), bem como a tese inclusivista (segundo a qual, apesar da salvação ser possível em outras tradições religiosas, esta se dá pela obra de Cristo) estão a grande circulação de informações sobre outras tradições religiosas, que questionam uma série de estereótipos que os líderes cristãos difundiam sobre elas, ao informar riquezas doutrinais com sentidos práticos inesgotáveis. Segundo Hick (1998), “As imensas riquezas espirituais do Judaísmo e do Islamismo, do Hinduísmo, do Budismo, da religião dos sikhs, do Confucionismo e do Taoísmo, bem como das religiões primevas da África, se tornaram melhor conhecidas no Ocidente e tenderam a desgastar a plausibilidade do antigo exclusivismo cristão (1998, p.14)".

Segundo John Hick (1998): “Atualmente, o pensamento cristão, em sua maior parte, realizou a passagem de um exclusivismo intolerante a um inclusivismo benevolente (1998, p.23)". A diferença entre o pluralismo e o exclusivismo e inclusivismo, consiste precisamente em que o pluralismo não prioriza nenhuma das religiões pós-axiais. O que caracteriza o exclusivismo é a centralidade da igreja cristã e de Cristo para a salvação dos homens (extraecclesiamnullasalus). O que caracteriza o paradigma inclusivista é a centralidade de Jesus, ainda que a salvação operada por ele possa ser

54Segundo John Hick (1998): “O Concílio Vaticano II (1963-1965) realçou e consolidou a nova forma de pensamento que estava tendo lugar há vários anos entre alguns dos mais audazes teólogos católico-romanos. Na realidade, o Vaticano $1 \mathrm{I}$ - embora não com todas e tantas palavras, naturalmente - repeliu a doutrina extraecclesiamnullasalus ao declarar que existe salvação fora da igreja visível; a redenção adquirida pelo sangue de Cristo é oferecida a todos os seres humanos, mesmo sem sua entrada formal na Igreja (1998, p.20)". 
realizada em outras tradições. Jesus Cristo é constitutivo para a salvação universal. Esse é o paradigma inclusivista. O paradigma pluralista quebra essa constitutividade e passa para o outro lado dessa linha divisória. Segundo Hick (1998): “Isso porque, no outro lado dessa linha divisória, o Cristianismo é visto em um contexto pluralista como uma das grandes religiões universais, uma das correntes de vida religiosa através das quais os sereshumanos podem ser salvificamente relacionados com aquela Realidade última conhecida pelos cristãos como o Pai Celestial (1998, p.23)”.

Para Hick (2000 \& 2005), o Real é experimentado de diversas maneiras nas culturas religiosas, isso significa que as diversas respostas que as grandes religiões dão à Realidade Última são igualmente válidas. Para dar consistência ao seu argumento ele retoma a distinção kantiana entre o que as coisas são para os homens (fenômenos) e o que as coisas são em si mesmas (númeno), que segundo ele (2000): “(..) foi amplamente confirmada por estudos nas áreas de psicologia cognitiva e da sociologia do conhecimento (2000, p.189)". Na percepção que temos do mundo, acessamos apenas o fenômeno e não a coisa em si. Os homens são ativos em toda percepção do mundo que o circunda. Na religião, segundo Hick, não será diferente. As diversas religiões se referem a uma mesma Realidade. Entretanto, essa realidade não pode ser abarcada totalmente por uma instituição religiosa. Segundo Hick (2005): “Assim, não se pode propriamente dizer que o Real em si é pessoal ou impessoal, que tem um propósito ou não, que é bom ou mau, que é substância ou processo, ou mesmo seja um só ou muitos (2005, p.52)". Quando dizemos que a Realidade Última é pessoal, o fazemos em função de nossos limites culturais. O mesmo se dá quando atribuímos a Realidade Última à impessoalidade. Todas essas denominações são formas humanas de conceber o Real, mas o Real é mais do que tudo que podemos apreender. Entretanto, Hick afirma que as diversas religiões mundiais são igualmente caminhos de salvação humana. Todas são respostas ao Real, mas condicionadas culturalmente. Nenhuma das respostas que as grandes religiões oferecem pode decidir sobre a supremacia de uma em detrimento das demais. Por isso, John Hick (2005) constata: “De fato, penso que podemos dizer que todo pensamento religioso sério afirma que a Realidade última, em sua realidade divina infinita, está absolutamente além de nossa compreensão (2005, p.89)". 
Enquanto respostas ao Real, marcadas pelos limites de cada cultura, delimitada pelo horizonte específico de sua formação, não podem abarcar o Real em sua totalidade. O Real é sempre maior que qualquer coisa que possamos imaginar. O Real é compreendido como o lugar a partir do qual todos os entes se constituem. Segundo Hick (2005), referindo-se à "Realidade": "Ela é a fonte e o fundamento de tudo (...) (2005, p.52)". O Real abarca tudo em si. As instituições religiosas são configurações culturais dessa "Realidade última" e como cada cultura compreende e apreende o sentido do mundo de forma parcial e precária, então nenhuma instituição religiosa pode julgar-se superior a outras. Enquanto culturais, elas não podem arrogar-se de conter a verdade absoluta sobre a Realidade última. Dentro de uma determinada comunidade histórica, o discurso a respeito do Real se traduz pelos limites da própria cultura. Segundo John Hick (2000): "Os conceitos segundo os quais tomamos consciência do Real desenvolveram-se de formas bastante distintas nas diferentes culturas da terra (2000, p.190)".

John Hick (2000) parte das formas concretas de religião e não da razão, e diz: “Assim se procedermos indutivamente a partir destas formas, adotando uma interpretação religiosa da mesma em oposição a uma interpretação naturalista, é provável que assumamos duas posições (2000, p.189)”. As duas posições que Hick assume e que diferencia a sua interpretação da religião da interpretação naturalista são: 1) Hick postula a existência de uma realidade transcendente última, que por não estar disponível ao conhecimento humano ${ }^{55}$, aparece apenas segundo as diversas formas de pensamento humano; 2) A identificação de que as diferentes maneiras de experimentar o Real (o transcendente) são igualmente legítimas em todas as religiões mundiais. Ao assumir que as diversas religiões são experiências diversas com a Realidade última, ele quer assumir que cada experiência religiosa é uma experiência com o transcendente e não o resultado de uma projeção meramente humana. Vimos análise semelhante em Schleiermacher, na qual a experiência religiosa consiste em que o influxo do Universo é intuído no finito e as diversas configurações religiosas são a objetivação dessa intuição do Universo, fazendo com que as diversas religiões positivas sejam compreendidas como

55Segundo John Hick (2000): “(...) quando digo que o real situa-se além do alcance de nossos conceitos humanos, não pretendo afirmar que ele esteja além do alcance de conceitos puramente formais, gerados de maneira lógica - tais como o conceito de situarse além do alcance de conceitos (não puramente formais)! (2000, p.190)". 
partes de um Todo (Infinito). John Hick (2000) diz: “Afirmar o Real é, desta forma, afirmar que a experiência religiosa não é somente uma construção da imaginação humana, mas é uma resposta ao Real - embora sempre uma resposta culturalmente condicionada (2000, p.192)". Entretanto, Hick (2000) afirma que "Contudo, é claro que não se experimenta o Real efetivamente seja como divindade em geral ou como absoluto em geral (2000, p.189)". O que experimentamos é o resultado da interação entre o Real e as condições históricas concretas de cada religião. O Real permanece tal como é, a saber, sem poder ser apreendido em si mesmo pelos homens, por isso, cada percepção que uma determinada cultura religiosa tem do Real, resulta numa forma distinta de religião. Por isso, John Hick (2000) diz:

\begin{abstract}
Consideremos, assim, a possibilidade de que uma realidade transcendente infinita é concebida de maneiras diferentes e, portanto, experimentada de diferentes maneiras e recebendo respostas diferentes dentro de nossas diversas formas religioso-culturais de sermos humanos (2000, p.188).
\end{abstract}

Por isso, ele diz: "Estas receptividades variáveis consistem de esquemas conceptuais dentro dos quais todo um leque de fatores pessoais, comunitários e históricos produziram variações ainda maiores (2000, p.189)". As grandes religiões são esquemas (fenômenos) do Real (númeno).

O esquematismo é um procedimento kantiano. Na CRP [1785] (1999), Kant diz que o conhecimento humano é precedido por categorias a priori do entendimento que são aplicadas aos objetos dados na experiência (intuições). Por isso, a nossa percepção é sempre ativa na hora de conhecer os objetos que experienciamos. As categorias são aplicadas às intuições (dados sensíveis) que fornecem a matéria do conhecimento, ao passo que as categorias dão a forma desse mesmo conhecimento. Conhecemos objetivamente os objetos, ainda que os tais objetos sejam dados na experiência humana e não em si mesmos. Por exemplo, se dissermos "o sol esquentou a pedra", relacionamos duas intuições sensíveis (o sol e a pedra) e as reunimos por meio da categoria de causalidade e, assim, podemos afirmar que sabemos a causa do calor na pedra.

Com relação à religião, segundo a compreensão de Kant, as diversas formas de religião positivas são formas sensíveis (esquemas) de manifestar à religião racional (inteligível). O esquema na religião não acontece como no 
conhecimento teórico, já que aqui não temos a ver com a teoria e sim com a prática (liberdade moral). A religião estatutária em Kant tem apenas a função de tornar intuitiva a religião verdadeira (a religião racional ou moral). Segundo Kant [1793] (2008): "Mas transformá-lo num esquematismo da determinação do objecto (para a ampliação do nosso conhecimento) é antropomorfismo, que num propósito moral (na religião) tem as mais prejudiciais consequências (2008, p.75)". Não há, em Kant, a possibilidade de um símbolo religioso expressar de modo completo o conceito puro de religião ${ }^{56}$. O símbolo é uma projeção da imaginação humana, por isso, se eles forem tomados no lugar da coisa mesma, cometemos um antropomorfismo, a saber, ter as representações sensíveis (construídas pela nossa imaginação de acordo com o tempo e lugar de sua formação) pelos conceitos racionais, que valem para todos e não apenas para a época na qual aquele símbolo tenha sido "esquematizado".

No pensamento de Hick (2000 \& 2005) não há um privilégio da religião natural e uma submissão da religião positiva. Ele também admite que as narrativas de cada religião são símbolos que buscam expressar, de acordo com os limites de cada época, a Realidade última. Hick não assume conceitos universais nesse esquematismo entre o transcendente e a manifestação cultural do Real. Ao contrário, cada conceito de divindade é desenvolvido de modos variados, de acordo com cada cultura específica. Por isso, para Hick (2005):

E a possibilidade para a qual quero apontar é que a Realidade inefável e última é passível de ser autenticamente experimentada em termos de conjuntos diferentes de conceitos humanos, como Javé, como a Santa Trindade, como Allah, como Shiva, como Vishnu, e novamente como Brahman, como Darmakaya, como Tao, e assim por diante, sendo que estas diferentes personae e impersonae ocorrem na interface entre o Real e nossas diferentes mentalidades e culturas religiosas (2005, p.49-50).

56Segundo Kant [1793] (2008): "Quero aqui apenas observar de passagem que, na ascensão do sensível para o supra-sensível, se pode decerto esquematizar (fazer apreensível um conceito por meio da analogia com algo de sensível), mas de nenhum modo se pode inferir, de acordo com a analogia, sobre o que pertence ao sensível, que ele deva atribuir-se igualmente ao supra-sensível (e alargar assim o seu conceito); e isto, sem dúvida, pela razão inteiramente simples de que iria contra toda a analogia semelhante raciocínio, o qual, em virtude de usarmos necessariamente um esquema para um conceito a fim de no-lo tornar compreensível (documentá-lo mediante um exemplo), quereria tirar a consequência de que ele há-de por força corresponder ao próprio objecto, como seu predicado (2008, p.75)". 
Com estabelecimento da experiência religiosa como o Real e a manifestação cultural numa forma particular de religião, bem como o fato do Real não poder ser conhecido plenamente e a forma cultural de uma religião sempre depender de seu contexto/limites históricos, leva-nos a concluir que nenhuma das religiões positivas pode arrogar-se de ser a única religião verdadeira. Para Hick, todas as respostas à Realidade última são igualmente religiões válidas.

Até aqui ainda não nos foi concedido um critério que nos possibilite julgar o que torna uma religião uma resposta válida. Perguntamos: qual é o critério que nos permite dizer que todas as religiões são respostas igualmente válidas? Porque todas são caminhos de salvação do homem. O que significa salvação?

\subsubsection{A religião como caminho de salvação}

Todas as grandes religiões são caminhos de salvação do homem. Cada uma delas possui uma soteriologia. Apesar de podermos perceber claramente diferenças entre os diversos projetos de salvação dentro de cada representação simbólica da religião, ficaríamos paralisados e não poderíamos extrair uma compreensão geral apenas nos elementos particulares de cada mito soteriológico. É necessária uma visão mais ampla, que saia dos particularismos. O perigo de aceitarmos a doutrina cristã como a mais viável no processo de salvação significaria compreender a salvação apenas como salvação cristã, assim como se compreendermos salvação como a salvação budista teríamos que aceitar apenas a salvação budista e assim por diante. Entretanto, John Hick (2000) empreende um processo de comparação entre as diversas doutrinas de salvação e chega a seguinte conclusão:

Contudo, se nos afastarmos um pouco destas diferentes concepções a fim de compará-las, penso que poderíamos vê-las, de maneira muito natural e apropriada, como formas diferentes da concepção mais fundamental de uma mudança radical, a qual vai de um estado profundamente insatisfatório a um estado ilimitadamente melhor (...) (2000, p.181-182).

Ele parte do elemento em comum a todos os projetos de salvação. O que de comum Hick encontra consiste sempre na necessidade de uma saída do eu para centrar-se no Real, que se traduz na profunda insatisfação com a condição 
presente do mundo para um estado melhor. A salvação humana consiste numa saída do egoísmo para o centramento no divino. O melhoramento é uma saída do ego e uma entrega ao Real. Por isso, segundo Hick (2000): "É esta a transformação humana à "semelhança" finita de Deus; e é esta mudança humana real que constitui a salvação (2000, p.175)". Uma transformação como resultado de uma experiência com a transcendência do Real, que resulta num descentramento do ego e um centramento no Real, caracteriza o que Hick entende por salvação/libertação. Como podemos avaliar a salvação nesse sentido?

Segundo John Hick (2000): “Assim, tem-se a impressão que somente podemos avaliar estes projetos de salvação à medida que somos capazes de observar seus frutos na vida humana (2000, p.183)". Já que não é possível adentrarmos no interior das ações, mas apenas a percebemos no tempo como fenômeno, o critério não poderá partir de um julgamento das intenções. Os frutos são os resultados visíveis de um progresso moral. Segundo Hick (2005): "Isso porque nosso progresso como peregrinos é nossa resposta de vida ao Real (2000, p.51)". Para julgarmos a supremacia ou não de uma tradição religiosa teríamos que mostrar na experiência os frutos de tal supremacia. Não basta aqui um julgamento a priori da questão. Tudo deve ser decidido a posteriori. Não adianta julgarmos a nossa religião superior se não formos capazes de tornar visíveis os frutos morais que cada tradição conseguiu deixar ver na experiência histórica .

A conclusão a que chega John Hick é que cada uma dessas grandes tradições são igualmente caminhos de libertação humana. Não significa que tudo o que é dito dentro de uma tradição religiosa seja meio de promover a libertação humana. O que John Hick colheu da experiência foram os efeitos bons e nocivos de cada uma dessas religiões ${ }^{57}$. Segundo Hick (1998): "Nesse

57Segundo John Hick (1998): "Mas, ao mesmo tempo, cada uma delas santificou males humanos perniciosos. O Hinduísmo, apesar de constituir um universo de sentido imensamente rico e poderoso, e apesar de mostrar o caminho da libertação interior, também valida o sistema hierárquico de castas da Índia, inclusive o fato de milhões serem relegados à posição de párias - uma injustiça que ainda persiste a despeito da sua abolição oficial na Constituição de 1947. A sociedade indiana tolerou a antiga prática da autoimolação de viúvas (suttee), e ainda tolera a contínua e cruel perseguição, e algumas vezes assassinato, das noivas cujo dote é julgado insuficiente. O Budismo, embora basicamente pacífico e tolerante, e apesar de infundir em milhões o ideal da existência não centrada no self, tem sido indiferente até bem recentemente a questões de justiça social, de sorte que muitos países budistas permaneceram por longas épocas num estado de desigualdade feudal. O Islamismo, embora convocando os fiéis à submissão e à paz com Deus, e embora 
ponto, deveríamos acrescentar que, devido à mesma natureza humana, as reivindicações de outras religiões à validade absoluta e a uma consequente superioridade igualmente sacralizaram a agressão violenta, a exploração e a intolerância (1998, p.15)". A conclusão a este respeito proposta por John Hick (2000) é que, tanto a religião cristã quanto outras tradições religiosas foram capazes de produzir frutos morais e frutos nocivos ao desenvolvimento humano. Hick (1998) diz:

Portanto, quando tentamos considerar as tradições religiosas como entidades históricas duradouras, encontramos em cada caso uma mistura complexa de elementos valiosos e nocivos. Cada uma delas forneceu uma estrutura efetiva de significado para milhões de adeptos, conduzindo-os através dos estágios da vida, oferecendo-lhes consolo nas doenças, penúrias e calamidades, e capacitando-os a celebrar comunitariamente suas fases de saúde, bem-estar e criatividade (1998, p.34).

O problema que se coloca diante desse quadro é o seguinte: qual é o critério que podemos colher para julgar adequadas as diversas tradições religiosas? Hick não nos fornece um critério universal, mas parte da especificidade da religião e dispensa um critério racional a priori como se deu em Kant. O seu critério é colhido somente depois de recorrer à experiência da religião concretamente, por isso, o critério que Hick nos oferece é dado a posteriori. Ele pressupõe que todas as diversas religiões são caminhos de salvação. Com isso, o elemento ético se torna o paradigma principal de julgamento das práticas religiosas. Por isso, ele diz (1998): "(...) é que não estamos em posição de reivindicar um poder, presumivelmente maior no Cristianismo do que em qualquer uma das outras grandes religiões universais, de produzir o tipo de transformação nos seres humanos que todos nós desejamos (1998, p.26)".

Podemos perceber que Hick tem uma preocupação em mostrar que uma religião verdadeira tem a característica de colocar a saída do ego para o Real no centro da mensagem religiosa. Hick (2000): "Nesse sentido mais amplo, podemos dizer que o cristianismo e estas outras grandes tradições são todas, igualmente, caminhos de salvação $(2000$, p.181)". O desapego de si para uma

promovendo uma fraternidade muçulmana que é notavelmente livre de preconceito racial, sancionou "guerras santas", intolerância fanática e punições bárbaras de mutilação e açoites, destinando ainda as mulheres, de uma maneira geral, a uma vida protegida mas estreitamente limitada(1998, p.35)." 
entrega aberta a uma Realidade transcendente é uma concepção que perpassa todos os projetos de salvação dentro das grandes religiões. Não esquece, no entanto, que esse princípio de ação convive com conteúdos revelados que se opõem a ele dentro de todas as religiões. Nem tudo na religião expressa a sua regra principal. Existem até doutrinas que contradizem esses ensinamentos. Segundo Hick (2005): "Existem elementos dentro de cada uma das grandes tradições mundiais com pouco ou nenhum valor religioso, ou que até mesmo trabalham diretamente contra a transformação salvífica (2005, p.72)”. Entretanto, se as religiões precisam viver harmoniosamente - e, para isso, é necessário um critério que abarque todas as religiões, sem que as especificidades culturais sejam substituídas por outra tradição igualmente cultural, que se julga superior e com o direito de impor a sua fé, mas que seja capaz de dialogar com outras tradições - é necessário extrair o que é central e comum a todas as tradições religiosas e o que nelas trabalha para o melhoramento moral dos homens.Mas qual é o critério que encontramos que seja comum a todas as religiões e que tem um potencial de promover a salvação do homem? Segundo John Hick (2000):

Minha sugestão de resposta é a seguinte: no nível mais básico, as grandes tradições fazem uso de um critério comum, uma vez que concordam em atribuir um papel central e normativo ao respeito altruísta por outras pessoas, papel que denominamos amor/compaixão (2000, p.184).

Hick percebe que todas as grandes religiões são universalmente caminhos de salvação por atribuírem ao amor/compaixão papel central e normativo. Amor/compaixão compreendido como um descentramento do egoísmo e um centramento no Real. É preciso alargar o pensamento em respeito às diferenças, mas sem se perder um critério para garantir um limite na definição de religião, a fim de que sejam possíveis aprendizados e correções mútuas, ou seja, para que a religiosidade de um não impeça a religiosidade de outro. Por isso, todas elas são respostas ao Real igualmente válidas. Esse papel central e normativo é expresso pela famosa regra de ouro que pode ser vista em todas as grandes religiões. Hick (2005) diz o seguinte: "Todas ensinam o ideal de buscar o bem dos outros na mesma proporção que o próprio (2005, p.110)". A proposta de um critério geral de avaliação das religiões foi visto na filosofia da religião de Kant. Entretanto, a proposta de Hick não busca o critério na 
razão e sim na própria experiência da religião.

\subsubsection{A hipótese Pluralista de Hick}

O que não foi dito ainda são os passos que Hick percorre para chegar a estas conclusões. Já dissemos que Hick não parte da razão e sim da experiência do transcendente vivida nas grandes religiões. Entretanto, as religiões mundiais são instituições históricas e enquanto tais carecem de um julgamento absoluto sobre as questões. Ele diz em sua hipótese pluralista que as diversas religiões são caminhos de salvação porque têm como ponto comum e central a exigência de uma abertura para o outro através da saída do ego para o centramento no divino ou Real. Isso é provado pelos seus frutos morais. As nocividades que as religiões cometeram resultam do esquecimento do amor/compaixão que caracteriza uma resposta válida ao Real. Por isso, nem todas as mitologias religiosas são proveitosas. Isso pode ser constatado pelo esforço de Hick em eliminar a ideia de que o cristianismo é a religião superior. Primeiro Hick diz que as diversas religiões são respostas válidas ao Real, e depois ele confirma seu argumento através do estudo das religiões. Como ele chega a esses resultados?

Hick (2005) assume que sua hipótese pluralista é feita com a finalidade de explicar, sempre desde o horizonte religioso, a existência de diversas religiões. Por isso, ele parte da história das religiões. Partindo das religiões, ele conclui que a religião não é uma projeção humana e que é ao mesmo tempo uma resposta cognitiva a uma realidade transcendente e opera um critério básico, desde dentro dessa fé religiosa. Por isso, de posse desse critério, Hick diz (2005): "(..) nem todas as formas de religião, incluindo-se aí, por exemplo, o satanismo ou os movimentos de Janestown e Waco, são tidos por respostas autênticas do Real (...) (2005, p.112)”.

Todos os homens operam com um critério moral sendo implícito ou explícito. Para provar isso, ele mostra o juízo que fazemos dos modelos que são apresentados na religião. Segundo Hick (2005): "São estas pessoas (ou melhor, algumas pessoas) que chamamos de santos (...). E quando as identificamos, fazêmo-lo por meio de critérios éticos num sentido amplo (2005, p.110)". As pessoas que chamamos santas são extremamente preocupadas com o bem-estar dos outros. Mas, por que o desapego do eu e o 
centramento no divino, que resulta na preocupação intensa com o seu bemestar, é o critério ético? Hick (2005) responde da seguinte maneira: "Porque as grandes tradições ensinam isso e eu as considero respostas autênticas do Real. Todas ensinam o ideal de buscar o bem dos outros na mesma proporção que o próprio (2005, p.110)".

Desde as religiões mundiais concretas - e não da religião da razão de Kant, ou por meio do privilégio do cristianismo na essência da religião de Schleiermacher - a hipótese do pluralismo erige um critério ético para o estabelecimento de um diálogo pautado no respeito à diferença e na preocupação do bem-estar dos outros. John Hick estabeleceu a regra de ouro como critério de julgamento das religiões. A regra de ouro diz que não se deve tratar os outros como não se quer ser tratado. Segundo as palavras do teólogo pluralista Vigil (2006):

O próprio diálogo religioso deve ser introduzido no espírito da regra de ouro. Há uma ética mínima a ser aplicada ao diálogo. Cada pessoa religiosa e cada uma das instituições religiosas deve fazer sua a regra de ouro no campo de sua própria relação com as outras religiões: não trates as outras religiões como não queres que tratem a sua $(2006$, p.244).

A questão parece ser conduzida no sentido de, não somente validar as diversas religiões mundiais, mas também oferecer o elemento central (pelo menos na visão de Hick) de todas as religiões. Elas são válidas somente enquanto são caminhos de salvação. A questão central nos remete à necessidade de sair de um programa religioso ortodoxo, fechado em si mesmo e com pretensão de superioridade, para um modo de ver que entende a religião como ortopraxia, ou seja, que religião tem a ver com a ação e não com o conhecimento teórico de como o Real é em si mesmo. John Hick retoma a definição de Kant (com suas devidas revisões) segundo a qual a ação assume o lugar central na função que a religião desempenha na vida dos homens. A religião, segundo Hick, não pode perder-se de sua função principal, a saber, uma atitude mais generosa, num descentramento do ego para um centramento no Divino.

Para o pensamento de Hick a experiência religiosa deve preceder qualquer conceito a priori. Essa compreensão está de acordo com Schleiermacher. Entretanto, a influência que a hipótese de John Hick recebe de Kant, além da 
distinção entre númeno e fenômeno, da busca de um critério para as religiões, ele também é influenciado por Kant ao afirmar que a religião tem função de tornar os homens melhores. Kant só admitia isso para quem merecesse por sua ação moral correta. Hick não parece fazer essa exigência - a salvação é um fim a que se propõem as práticas religiosas em geral, inclusive as estritamente rituais. A ideia de prioridade prática da religião, por outro lado, é mesmo uma concordância entre as filosofias da religião de Kant e Hick. A religião tem como prioridade uma ortopraxia, e uma crítica à ortodoxia que esquece da verdadeira função da religião, que consiste em tornar os homens melhores e contribuir para promover a paz no mundo. 


\section{Conclusão}

O presente trabalho teve como tarefa inicial elucidar a relação entre conceito racional ou moral de religião e sua relação com as religiões positivas no pensamento de Kant. Nesse passo inicial nosso objetivo era mostrar que o conceito de religião racional é aplicado às religiões positivas, num processo se reinterpretação dos conteúdos destas, no qual o resultado será a primazia da religião racional sobre a religião positiva.

O trabalho procurou, no primeiro capítulo, mostrar o modo como, partindo da moral Kant, chega ao conceito racional de religião. Foi mostrado que o conceito racional de religião é resultado de exigências morais e não pode ser confundido com os conteúdos revelados de uma religião positiva, já que a revelação está restrita ao tempo e lugar no qual ela se formou, ao passo que o conceito racional de religião pode ser comunicado a todos os homens universalmente. O conceito de religião racional é uma ideia da razão (conceito que não pode ser dado na experiência), e por isso, não poderemos encontrá-lo realizado numa forma histórica de religião positiva. A religião, para Kant, é religião natural e não revelada.

No segundo capítulo, procuramos mostrar que o conceito racional de religião é usado como critério para interpretar os conteúdos da religião positiva de tal modo que nada na religião positiva teria valor se não fosse possível remetê-la ao conceito racional de religião. O livro A religião... [1793] (2008) nos mostrou que determinada religião nos limites da simples razão consiste no resultado da interação entre religião racional e religião positiva, sendo que a religião racional é a única que pode fazer parte de uma ética pura, ao passo que a religião positiva contém, além do potencial para promover a moralidade, elementos da história e da revelação.

Como exigência do objeto total da lei moral, o homem está obrigado a promover o sumo bem comunitário no mundo. Entretanto, os seus esforços nesse sentido são sempre deficitários. O sumo bem comunitário é a ideia de uma comunidade ética, onde não há contradição entre virtude e felicidade, autonomia e religião, onde a lei de um é a lei de todos, e os homens são livres e racionalmente determinados. Essa comunidade ética é uma ideia, e enquanto ideia ela não pode ser dada na experiência. O homem não pode realizar o 
sumo bem comunitário. Ele pode promovê-lo, mas apenas Deus pode realizálo. Por isso, a religião é a lei moral como mandamento divino, dado que apenas Deus pode realizar o sumo bem comunitário, reunir natureza e liberdade e garantir que a virtude receba como consequência a virtude.

A realização da ideia de religião é a superação das formas imperfeitas de representá-lo na religião positiva e o estabelecimento do sumo bem comunitário no mundo. Os homens devem promover o sumo bem comunitário no mundo e ter uma fé racional de que Deus realizará o fim moral do mundo. O problema é que não podemos provar teoricamente que existe tal fim $a$ priori para as religiões. Deus é uma afirmação da fé racional e não um objeto que podemos conhecer objetivamente. Não importa para Kant o que Deus seja em si mesmo. Para ele é importante apenas que Deus seja compreendido como uma ideia que atende às exigências morais.

Kant [1793] (2008) empreende uma crítica aos conteúdos revelados da religião positiva, exigindo que os conteúdos revelados ou institucionais da religião positiva não estejam em desacordo com o conceito de religião racional. Caso a revelação só tenha valor em si mesma, sem ser remetida ao conceito de religião moral, ela perde a sua função. A função da religião positiva é promover o sumo bem comunitário no mundo. Para que a religião positiva possa contribuir para o desenvolvimento moral dos homens (promover o sumo bem comunitário no mundo), ela deve ser interpretada à luz do conceito racional de religião. O verdadeiro conteúdo de uma religião positiva não deve ser reduzido ao tempo e lugar no qual ela foi originada. O verdadeiro conteúdo da religião positiva é o que ela tem de potencial para mostrar a religião moral. Tudo o que tem de verdadeiramente útil na religião positiva é o seu potencial em promover a religião racional. Desse modo, práticas contrárias à moral são rejeitadas como práticas falsas.

A religião positiva é uma forma sensível de representar a religião racional. Nessa representação, ela não alcança a coisa em si mesma. O símbolo religioso deve ser remetido ao seu verdadeiro significado, que não é o seu conteúdo histórico fechado em si, mas o seu conteúdo moral e racional. O esforço de remetimento de todo o símbolo ao seu real significado leva à necessidade de sua substituição pelo que ele de fato mostra, a saber, a religião moral. O que temos na religião positiva é uma representação frágil e limitada da religião racional. A religião racional é compreendida como uma 
esfera mais ampla, na qual a religião positiva é uma parte sempre limitada. A religião positiva carece sempre de uma revelação. A revelação está sempre reduzida a tempo e ao lugar do qual ela se originou, ao passo que o conceito de religião racional pode ser comunicado a todos os homens. Por isso, a religião positiva deve tender sempre para religião racional. A sua meta consiste em promover a verdadeira religião e não assumir o seu lugar.

Para Kant [1793] (2008), podemos até dizer que uma religião nos limites da simples razão é uma "religião verdadeira", mas ela pode ser dita "verdadeira" apenas porque aponta para o conceito racional de religião. Em função da prioridade da religião racional em face da religião positiva, a missão da religião positiva é promover a religião racional. A religião racional não se esgota na religião positiva. O destino da religião positiva é, portanto, a sua substituição pela religião racional. Kant [1793] (2008) prenuncia o fim das religiões positivas e a primazia da religião racional.

No terceiro capítulo, mostramos que o paradigma de Kant, que interpreta a religião positiva a partir da religião natural, é, sob influência de Schleiermacher, substituído por um viés que parte da experiência da religião e não de um conceito puro da razão. Schleiermacher [1799] (2000) parte da experiência religiosa e não da razão. Constatou-se ainda que, no pensamento contemporâneo, o filósofo e teólogo John Hick, através de sua hipótese pluralista, habilita-nos a deduzir que Kant ainda exerce grande influência no mundo atual concernente ao problema do pluralismo religioso, embora Hick siga a tendência inaugurada por Schleiermacher de valorizar a experiência religiosa ao refletir filosoficamente sobre o tema.

A hipótese pluralista sugere uma compreensão de religião que abarque todas as grandes religiões positivas. Assim como Kant, Hick acredita que todas as formas de religião positivas são fenômenos. Para Kant, as religiões positivas são fenômenos da religião racional. Para Hick, aquilo que as religiões positivas cultuam são fenômenos do Real, e cada uma das formas de religião positiva são formas igualmente válidas de salvação dos homens. A religião é válida enquanto tem o papel de retirar os homens de um centramento no ego para um recentramento no divino (a salvação). Então, assim como para Kant, a hipótese pluralista entende que a religião tem como meta central a prática e não a teoria, sendo antes uma ortopraxia e não uma ortodoxia. 
A atualidade de Kant consiste precisamente em duas preocupações fundamentais da religião: 1) a necessidade de um critério moral para interpretarmos os conteúdos da religião positiva, dada a importância de critérios para a sociedade, que possam distinguir entre uma religião que quer tornar os homens melhores e aquelas que podem lhes ser nocivas; 2) a necessidade de tornar compreensível, por um processo de tradução racional dos conteúdos revelados da religião positiva, principalmente em função do novo quadro plural das religiões, que vivem cada vez mais dentro de um mesmo espaço, sendo obrigadas a conviverem no dia a dia e no espaço político. É necessários termos um critério para julgarmos uma religião que serve ao desenvolvimento dos homens para o moralmente melhor na sua distinção das religiões que podem ser nocivas à liberdade e autonomia dos sujeitos racionais.

Concluímos que o pensamento de Kant ainda é uma fonte a partir da qual o estudo das religiões e a necessidade de um critério para convivência que precisa ser estabelecida entre elas no espaço público tornam a sua filosofia importante para o atual debate da filosofia da religião. 


\section{Referências}

ALMEIDA, Guido. "Crítica, dedução e facto da razão". Analytica. vol.4, n.1, Rio de Janeiro, 1999.

ALSTON, William. Perceiving God - The Epistemology of Religious Experience.London: Ithaca, 1991.

CAYGILl, Howard. Dicionário Kant. Tradução Álvaro Cabral. Rio de Janeiro: Jorge Zaar, 2000.

Eliade, Mircea [1957]. O Sagrado e o Profano. São Paulo: Martins Fontes, 1992.

ESTEVES, J. A Dedução do Imperativo Categórico na Fundamentação III.Studia Kantiana, Rio de Janeiro, Rio de Janeiro, v. 5, n. número I, p. 79 $104,2003$.

Liberdade e moralidade em Kant. Tese de doutorado. Universidade Federal do Rio de Janeiro, UFRJ, 1998.

GIACOIA Jr., Oswaldo. Reflexões sobre a noção de mal radical. Studia Kantiana. Revista da Sociedade Kant Brasileira. Vol. I, no. 1, set. 1998, pp. 183-202.

HANH, Alexandre. A função da antropologia moral na filosofia prática de Kant. Tese de doutorado. Universidade de Campinas (Unicamp), 2010.

HECK, José. O princípio do amor próprio em Kant. Revista Síntese, Belo Horizonte. V26, N.85, 1999.

HERRERO, Francisco J. (1991): Religião e História em Kant. Tradução de José A. Ceschin. São Paulo: Loyola.

HICK, John. A metáfora do Deus encarnado. Tradução Luiz Henrique Dreher. Petrópolis: Ed. Vozes, 2000.

. Teologia cristã e pluralismo religioso: o arco-íris das religiões.

Tradução Luiz Henrique Dreher. São Paulo: Attar editorial, Programa de pós graduação em Ciência da Religião UFJF, 2005. 
. O caráternão-absolutodocristianismo, In: Disputed Questions in

Theology and the Philosophy of Religion, Tradução Luiz Henrique Dreher. New Haven: Yale University Press, 1998, p. 77-101.

HÖFFE, Otfried. Immanuel Kant. Tradução de Christian Viktor Hamm e Valério Rohden. São Paulo: Ed. Martins Fontes, 2005.

JAMES, William. The Varieties of Religious Experience. New York: The Modern Library, 1902.

KANT, Immanuel. A metafísica dos costumes. Tradução, textos adicionais e notas Edson Bini. Bauru/SP: EDIPRO, 2 ${ }^{\text {a }}$ ed. rev., [1797] 2008 (Série Clássicos Edipro).

Antropologia de um ponto de vista pragmático. Tradução: Clélia Aparecida Martins. São Paulo: Iluminuras, [1798] 2006.

A religião nos limites da simples razão. Tradução: Arthur Mourão. Lisboa: Edições 70, [1793] 2008.

- Conflito das faculdades. Tradução Arthur Mourão. Lisboa: Edições 70, [1798]2008.

. Crítica da razão prática. Tradução Valério Rohden. São Paulo: Martins Fontes, [1788] 2002.

Que significa orientar-se pelo pensamento? Tradução: Arthur Mourão. In: Lusosofia: biblioteca on-line de filosofia. Site: www.lusosofia.net. Acesso em janeiro de 2011.

Crítica da razão pura. Tradução Valério Rohden e UdoBaldurMoosburger. São Paulo: Editora Nova Cultural, [1781] 1999.

Fundamentação da metafísica dos costumes. Tradução de Guido de Almeida. São Paulo: Discurso editorial: Bancarolla, 2009.

Os progressos da metafísica. Tradução de A. Morão, Lisboa, Edições 70, 1985 [1804], 143 páginas. 
Artur Morão. Lisboa: Edições 70, [1781] 1987.

KIERKEGAARD, S.A [1843]. Temor e tremor. São Paulo: Abril Cultural, 1979. (Os Pensadores).

KLEMME, Heiner F. A liberdade do arbítrio e o domínio do mal: a doutrina de Kant do mal radical entre moral, religião e direito. Studia Kantiana. 15 (2013): 5-37.

LOPARIC, Z. O fato da razão. Uma interpretação semântica. Analytica, Vol.04, n.1, 1999.

OLIVEIRA, Davison. A consciência originária do infinito e sua manifestação na história segundo Schleiermacher. In: PLURA, Revista de Estudos da Religião, Vol.2, nº.02, 2011,pg. 140-165.

OTTO, Rudolf [1917]. O Sagrado: um estudo do elemento não-racional na idéia do divino e a sua relação com o racional. (tradução: PrócoroVelasquez Filho). São Bernardo do Campo: Imprensa Metodista, 1985.

PAVÃO, Agnaldo. O moralmente bom e o moralmente mau em Kant: uma discussão com ZeljkoLoparic. Kant e-Prints. Campinas, Série 2, v. 5, n. 3, p. 109 - 131, número especial, jul.- dez., 2010.

PEREZ, Daniel Omar. Política, Religión y Medicina en Kant: El Conflicto de las Proposiciones.2007. Cinta de Moebio 28: 91-103.

SCHLEIERMACHER, Friedrich. Sobre a religião. Tradução Daniel Costa. São Paulo: Novo Século, 2000.

SPINELli, Letícia Machado. A Religião nos limites da simples razão. Kant e-Prints. Campinas, Série 2, v. 8, n. 1, p.127-151 jan.- jun., 2013 Kant e o Sumo bem Comunitário. Florianópolis,

Ethic@, v. 11, n. 1, p. 37 - 57. Jun. 2012.

VIGIL, Jose Maria. Teologia do pluralismo religioso para uma releitura pluralista do cristianismo. Tradução Maria Paula Rodrigues. São Paulo: Ed. Paulus, 2006. 
ZINGAnO, M. Razão e História em Kant. São Paulo: Brasiliense, 1989. 